\title{
THE ROTIFERS OF SPANISH RESERVOIRS: ECOLOGICAL, SYSTEMATICALAND ZOOGEOGRAPHICAL REMARKS
}

\author{
Jordi de Manuel Barrabin \\ Departament d'Ecologia, Universitat de Barcelona.Avd.Diagonal 645,08028 Barcelona. Spain,jdemanu@ pie.xtec.es
}

\begin{abstract}
This article covers the rotifer data from a 1987/1988 survey of one hundred Spanish reservoirs. From each species brief information is given, focused mainly on ecology, morphology, zoogeography and distribution both in Spain and within reservoirs. New autoecological information on each species is also established giving conductivity ranges, alkalinity, $\mathrm{pH}$ and temperature for each. Original drawings and photographs obtained on both optical and electronic microscopy are shown of the majority of the species found.

In total one hundred and ten taxa were identified, belonging to 101 species, representing 20 families: Epiphanidae (1): Brachionidae (23); Euchlanidae (1); Mytilinidae (1); Trichotriidae (3): Colurellidae (8); Lecanidae (15); Proalidae (2); Lindiidae (1); Notommatidae (5); Trichocercidae (7); Gastropodidae (5); Synchaetidae (11); Asplanchnidae (3); Testudinellidae (3); Conochiliidae (5); Hexarthridae (2); Filiniidae (3); Collothecidae (2); Philodinidae (Bdelloidea) (1).

Thirteen species were new records for the Iberian rotifer fauna: Keratella ticinensis (Ehrenberg); Lepadella (X.) astacicola Hauer; Lecane (M.) copeis Harring \& Myers; Lecane tenuiseta Harring: Lecane (M.)tethis Harring \& Myers; Proales fallaciosa Wulfert; Lindia annecta Harring \& Myers; Notommata cerberus Hudson \& Gosse; Notommata copeus Ehrenberg: Resticula nyssa Harring \& Myers; Trichocerca vernalis Hauer; Gastropus hyptopus Ehrenberg: Collotheca mutabilis Hudson.
\end{abstract}

Key Words: Rotifera, plankton, heleoplankton, reservoirs

\section{RESUMEN}

Este artículo proporciona información sobre los rotíferos hallados en el estudio 1987/88 realizado sobre cien embalses españoles. Para cada especie se da una breve información, fundamentalmente sobre aspectos ecológicos, morfológicos, zoogeográficos, asi como de su distribucidn en España y en los embalses. Se aporta información a la autoecología de cada especie (rangos de conductividad, alcalinidad, pH, temperatura). Se proporcionan las ilustraciones originales de la mayor parte de las especies (dibujos i microfotografias con microscopía óptica o electrónica).

Se identificaron ciento diez taxones, correspondientes a 101 especies, representando 20 familias: Epiphanidae. (I); Bruchionidae (23); Euchlanidae (1); Mytilinidae (1); Trichotriidae (3); Colurellidae (8); Lecanidae (15); Proalidae (2); Lindiidae (I); Notommatidae (5); Trichocercidae (7); Gastropodidae (5); Synchaetidae (1I); Asplanchnidae (3); Testudinellidae (3): Conochiliidae (5);Hexarthridae (2); Filiniidae (3);Collothecidae (2);Philodinidue (Bdelloidea)(1).

Trece especies son nuevas citas para lafauna ibérica de rotiferos: Keratella ticinensis (Ehrenherg); Lepadella (X.) astacicola Hauer; Lecane (M.) copeis Harring \& Myers; Lecane tenuiseta Harring; Lecane (M.) tethis Harring \& Myers; Proales fallaciosa Wulfert; Lindia annecta Harring \& Myers; Notommata cerberus Hudson \& Gosse; Notommata copeus Ehrenherg; Resticula nyssa Harring \& Myers; Trichocerca vernalis Hauer; Gastropus hyptopus Ehrenberg; Collotheca mutabilis Hudson.

Palabras clave: Rotifera, plancton, heleoplancton, embalses

\section{INTRODUCTION}

One hundred and three reservoirs were extensively studied in 1972-75 (Margalef et al. 1976), and revisited 15 years later (1987-88). Both studies examined the regional limnology of a country with scarcity of natural lakes.

Rotifers constitute an important part of the freshwater zooplankton. They are usually unimportant in terms of biomass (Ruttner-Kolisko, 1974), but 
play a major role in energy transfer and nutrient cycling (Makarevic \& Likens, 1979). Rotifers may disperse by means of their resting eggs and their biogeography has been subject of intense controversy (Dumont, 1980, 1983; De Ridder, 1981; Shiel et al., 1989; De Manuel et al. 1992). Knowledge of the rotifer fauna of Spain is scarce. Velasco (1991) included 349 taxa but for a temperate region, this number seems too low. The most complete review of planktonic rotifers is found in Guiset $(1976,1977 \mathrm{a})$, where the distribution of planktonic rotifers is related to reservoir typology.

There is large literature, including identification keys with abundant information on ecological and systematical aspects of rotifers from different regions of the world. In this sense, Pontin (1978) for the British Islands, Stemberguer (1979) for the Laurentian Great Lakes, Braioni and Gelmini (1983) for Italy, Pourriot \& Francez (1986) for France and Koste and Shiel (1987a, 1989a, 1989b, 1990ab, 1991) and Shiel \& Koste (1992) for Australia, are all examples of rotifer revisions and systematic compilations on systematical keys. However, not much autoecological and sinecological information of species is reported in these works.

This paper records all rotifer taxa found in a 1987-89 survey of one hundred and three Spanish reservoirs. In spite of the fact that samples were collected from plankton, a large number of taxa were typically littoral species, both peryphitic and heleoplanktonic.

The aim of this paper is to identify and determine the occurrence of planktonic and heleoplanktonic rotifers in Spanish reservoirs. For each taxon a brief bibliographical revision on ecological, systematical and biogeographical aspects is given first. Following, ranges of some physical and chemical variables (conductivity, alkalinity, $\mathrm{pH}$ and temperature) are indicated for localities were each species was found. Data on the geographical distribution of the taxa recorded in Spain is also given. The work includes original drawings and microscopic photographs of the majority of taxa.

Other investigations on rotifers deriving from this extensive survey may be found elsewhere: brachionidae were reported in De Manuel (1991); communities and assemblages in De Manuel \& Armengol (1993); relationships of each species with with physical, chemical and biological variables in De Manuel \& Jaume (1993, 1994) and a comparison between relationships found in the previous study and changes in distribution in Guiset \& De Manuel (1993).

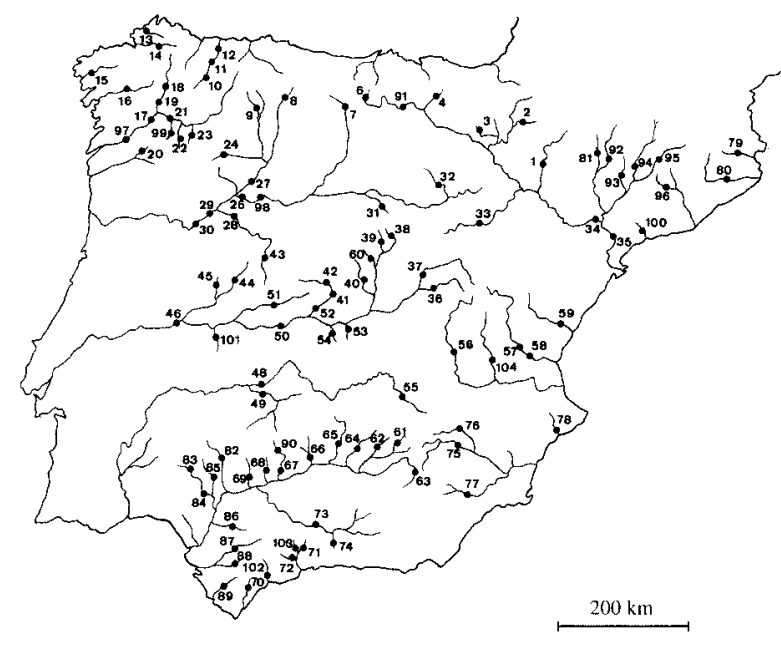

Figure 1. Reservoirs studied: 1 La Sotonera; 2 Yesa; 3 Alloz; 4 Urrunaga; 6 Ebro; 7 Aguilar de Campoo: 8 El Porma; 9 Barrios de Luna; 10Salime; 11 Doiras; 12 Arbbn: 13 Forcadas: 14Ribeira; 15 Fervenza; 16 Portodemouros; 17 Velle; 18 Belesar; 19 Os Peares; 20 As Conchas; 21 San Esteban; 22 Chandrexa: 23 Bao: 24 Cernadilla: 26 Villalcampo; 27 Ricobayo; 28 Almendra; 29 Aldeadavila; 30 Saucelle; 31 Linares del Arroyo; 32 Cuerda del Pozo; 33 Tranquera: 34 Mequinença; 35 Flix; 36 Buendía; 37 Entrepefias; 38 El Vado; 39 El Atazar; 40 Santillana: 41 San Juan; 42 Burguillo; 43 Santa Teresa; 44 Gabriel y Galán; 45 Borbollón; 46 Alcántara; 48 Orellana; 49 Zújar; 50 Valdecafias; 51 Rosarito; 52 Cazalegas: 53 Guajaraz; 54 Torcón; 55 Pefiarroya; 56 Alarcón; 57 Benaixeve; 58 Loriguilla; 59 Sitjar; 60 El Vellón; 61 Guadalmena; 62 Guadalén; 63 Tranco de Beas; 64 Rumblar; 65 Jandula; 66 Guadalmellato; 67 La Brefia; 68 Bembezar; 69 Retortillo; 70 Guadarranque; 71 Guadalteba: 72 Conde de Guadalhorce; 73 Iznajar; 74 Los Bermejales: 75 Cenajo; 76 Talave; 77 Puentes; 78 Amadorio; 79 Boadella; 80 Susqueda; 81 El Grado; 82 El Pintado; 83 Aracena; 84 La Minilla; 85 Cala; 86 Torre del Águila; 87 Bornos; 88 Guadalcacin; 89 Celemin: 90 Guadalnuño; 91 Sobron; 92 Barasona; 93 Sta. Anna: 94 Camarasa; 95 Oliana: 96 Sant Ponç; 97 Frieira; 98 San Romin; 99 Mao (Leboreiro); 100 Riudecanyes; 101 Cáceres (Guadiloba); 102 La Concepción; 103 Guadalhorce; 104 Contreras. 


\section{STUDY AREA AND METHODS}

The study of Spanish reservoirs was carried out in two extensive surveys. One survey was done between November 1987 and March 1988, approximately the mixing period. The second survey was carried out from July to September 1988 , when the water column was generally stratified. Fig. 1 gives the location of each reservoir.

Rotifer samples were collected with a Nytal plankton net $40 \mu \mathrm{m}$ mesh size. Two replicate samples were taken from each reservoir. Each sample was taken as a vertical haul from $20 \mathrm{~m}$ deep to the surface in the deepest part of the reservoir. A qualitative sample was also taken as an horizontal haul 1-3 m deep while navigating softly about 2 minutes. Samples were anaesthetized with carbonated water and progressively preserved with formaldehyde to reach a $4 \%$ solution in water. A series of measurements of physical, chemical and biological variables were carried out in situ. Detailed information on methods from limnological investigations conducted in Spanish reservoirs can be found in Margalef et al., (1976); Armengol et al., (1990) and Riera et al., 1992.

The work of the European rotifer fauna of Voigt (1957) and revised by Koste (1978) has been widely used as a general guide for identification. However, some reviews and monographs on particular genera and families have been used too: Ahlstrom $(1940,1943)$ and Koste \& Shiel (1987a) for genera Brachionus and Keratella; Stemberger (1979) for Synchaeta species and Harring (1916) and Harring \& Myers (1916, 1922, 1926) and Koste \& Shiel (1990a) for genera Lepudella, Lecane and Cephalodella.

Mastax analyse were carried out in some taxa for taxonomic identifications. Some specimens (or part of them) were drawn with a camera lucida and, occasionally, photographed. Scanning electron microscopy (SEM) was used for distinguishing details of loricated rotifers, and was especially useful for the family Brachionidae. Preparation of specimens for SEM observation was made following Ansellem \& Clement (1981).
Table 1. Number of species from each family identified in Spanish reservoirs (1987/88). Número de especies de cadafamiliu identificadas en los embalses españoles (1987/88).

\begin{tabular}{lc}
\hline Famílies & no d'espècies \\
\hline Monogononta & \\
\hline F. Epiphanidae & 1 \\
F. Brachionidae & 23 \\
F. Euchlanidae & 1 \\
F. Mytilinidae & 1 \\
F. Trichotriidae & 3 \\
F. Colurellidae & 8 \\
F. Lecanidae & 15 \\
F. Proalidae & 2 \\
F. Lindiidae & 1 \\
F. Notommatidae & 5 \\
F. Trichocercidae & 7 \\
F. Gastropodidae & 5 \\
F. Synchaetidae & 11 \\
F. Asplanchnidae & 3 \\
F. Testudinellidae & 3 \\
F. Conochiliidae & 2 \\
F. Hexarthridae & 5 \\
F. Filiniidae & 2 \\
F. Collothecaceae & 3 \\
Digononta & 2 \\
F. Philodinidae & \\
& \\
& \\
&
\end{tabular}

\section{ROTIFERS OF THE RESERVOIRS. ECOLOGIC, SYSTEMATIC AND ZOOGEOGRAPHICAL ASPECTS}

The 1987/1988 survey of Spanish reservoirs have been identified 110 rotifer taxa, corresponding to 101 species (Table 2) and representing 20 families (Table 1). Thirty five of these taxa were euplanktonic species while and the others were mainly heleoplanktonic. Thirteen species are new records for the rotifer fauna of Spain. Occurrence and abundance of each species in reservoirs is given in De Manuel (1997).

Rotifers are organized here by families, ordered according traditional criteria of Remane (1929-1933), and later modified by Koste (1978). Species in each family are ordered alphabetically. 
Tabla 2. Planktonic and heleoplanktonic species, grouped by families, found in 101 studied Spanish reservoirs (1987-88). ${ }^{*}$ new records for Spain. Especies planctónicas y heleoplanctonicas, agrupadas por familias, que han sido halladas en los 101 embalses estudiados (1987-88). * nuevas citas para España.

(Monogononta)

O. Ploimida

F. Epiphanidae Epiphanes senta

F. Brachionidae Anuraeopsis fissa Brachionus angularis

$B$. bidentata

B. budapestinensis

$B$. calyciflorus

B. falcatus

B. leydigi

B. plicatilis

B. quadridentatus

B. urceolaris

Keratella cochlearis

$K$. irregularis

$K$. quadrata

K. testudo

$K$. ticinensis *

$K$. tropica

$K$ serrulata

K. valga

Kellicottia longispina

Notholca acuminata

N. labis

N. squamula

Platyias quadricornis

F. Euchlanidae Euchlanis dilatata

F. Mytilinidae Lophocharis salpina

F. Trichotriidae Trichotria pocillum

T. tetractis

Wolga spinifera

F. Colurellidae

Colurella adriatica

C. colurus

C. uncinata

Lepadella acuminata

L. patella

L. ovalis

L. rhomboides

\section{L. (X.) astacicolu *}

F. Lecanidae

Lecane (M.) bulla

L. (M.) closterocerca

L. (M.) copeis *

L. crepida

L. flexilis

L. (M.) hamata

L. hastata

L. inermis

L. luna

L. (M.) lunaris

L. mira

L. (M.) scutata

L. (M. ) stenroosi

L. tenuiseta*

L. (M.) tethis *

F. Proalidae

Proales fallaciosa*

F. Lindiidae Lindia annecta *

F. Notommatidae

Cephalodella forficula

C. gibba

Notommatu cerberus *

N. copeus *

Resticula nyssa *

F. Trichocercidae

Trichocerca cylindrica

T. porcellus

T. pusilla

7: rousseletti

T. similis

7: stylata

7: vernalis *

F. Gastropodidae

Ascomorpha ecuudis

A. ovalis

A. sultans

Gastropus hyptopus *

G. stylifer
F. Synchaetidae

Polyarthra olichoptera

$P$. euryptera

1? major

1? remata

$p$ vulgaris

Ploesoma hudsoni

P truncatum

Synchaeta kitina

S. oblonga

S. pectinata

S. stylata

F. Asplanchnidae

Asplanchna brightwelli

A. girodi

A. priodonta

Gnesiotrocha

S. O. Flosculariaceae

F. Testudinellidae

Pompholyx sulcata

Testudinella patina

7: emarginula

F. Conochiliidae

Conochilus coenobasis

C. dossuarius

C. hippocrepis

C. natans

C. unicornis

F. Hexarthridae

Hexarthra fennica

H. mira

F. Filinidae

Filinia longiseta

F. opoliensis

F. terminalis

S.O. Collothecaceae

F. Collothecidae

Collotheca mutabilis *

C. pelagica

(Digononta)

O. Bdelloidea

F. Philodinidae

Rotariu neptunia 
Table 3. Number of reservoirs and inventories where species of the genus Polyarthra occurred in the survey 1987/88. Número de embalses y muestras en los que se ha encontrudo especies del género Polyarthra en el estudio de 1987/88.

\begin{tabular}{lccc}
\hline Polyarthra species & $\begin{array}{c}\text { Number of } \\
\text { stratified reservoirs }\end{array}$ & $\begin{array}{c}\text { Number of' } \\
\text { mixed reservoirs }\end{array}$ & $\begin{array}{c}\text { Number of' } \\
\text { inventories }\end{array}$ \\
\hline P. dolichoptera & 16 & 31 & 47 \\
P. euryptera & 9 & 7 & 16 \\
P. mujor & 54 & 45 & 99 \\
P. remata & 31 & 31 & 62 \\
P. vulgaris & 75 & 68 & 143 \\
P. eurqpteru /P. remutu & 4 & 2 & 6 \\
P. euryptera / P. vulgaris & 7 & 4 & 11 \\
P. euryptera / P. major & 4 & 4 & 3 \\
P. eurypteru / P. dolichopteru & 2 & 1 & 29 \\
P. vulguris / P. dolichopteru & 13 & 20 & 42 \\
P. vulgaris / P. remuta & 22 & 14 & 19 \\
P. mujor / P. dolichopteru & 5 & 26 & 67 \\
P. major / P. vulguris & 41 & 14 & 29 \\
P. mujor / P. remutu & 15 & 11 & 15 \\
P. dolichopteru / P. remuta & 5 & & 3 \\
\hline
\end{tabular}

Family EPIPHANIDAE

Genus Epiphanes Ehrenberg

(Some literature includes this genus in the family Brachionidae)

Epiphanes senta (Muller, 1773)

Vorticella senta Miiller, 1773; Hydutina senta Ehrenberg, 1830; Epiphanes senta (Miiller) after Harring, 1913.

Ecology. Species are mainly heleoplanktonic, but can be found occasionally in plankton samples. Preferentially in small waterbodies, rare in lakes and reservoirs. More common in eutrophic water, it tolerates salinity (Ruttner-Kolisko, 1974). Resting eggs may resist long periods of drought, and their presence is possible in temporary waters. Some flagellate alga as Phacus and Euglena, are frequent components of its diet (Pourriot, 196.5, 1977).

Cond: $206.3 \mu \mathrm{S} \mathrm{cm}^{-1}$; Alk: 1767 peq $\mathrm{l}^{-1}$; pH: 7.52; Temp: $9.87^{\circ} \mathrm{C}$

Morphological features of interest. Present two coulorless eyes. Uncus with six teeth and a very characteristic fulcrum, short and flat. Resting eggs completely covered by abundant short seta.

Geographical distribution. Cosmopolite. In Spain is only found occasionally.
Distribution in reservoirs. Rare. In last survey it was only present in winter samples from Ricobayo reservoir (27).

Family BRACHZONZDAE

Genus Anuraeopsis Lauterborn

Anuraeopsis fissa (Gosse, 1851)

Anuraea fissa Gosse, 1851; Anuraeopsis fissa Gosse, 1886.

Ecology. Planktonic rotifer, warm estenoterm. Termophil from eutrophic environments (Margalef, 1947, 1955). More frequent in small waterbodies. Feeds on bacteria and detritus (Pourriot, 1977). Anuraeopsis fissa may appear in the stomache contents of Asplanchna (Guiset, 1977c).

Cond: $183.4-351.3 \mu \mathrm{S} \mathrm{cm}^{-1}$; Alk: $1297.2-1652$ $\mu$ eq $\mathrm{l}^{-1}$; pH: 8-9.16; Temp: $23-25.5{ }^{\circ} \mathrm{C}$

Morphologicalfeatures of interest. The species is polymorphic in shape and size (Berzins, 1962). It does not present foot nor caudal spines as other brachionids. Asexual eggs present a short peculiar protuberance where the animal is subjected with the Weber organ (difficult to observe in contracted individuals). 


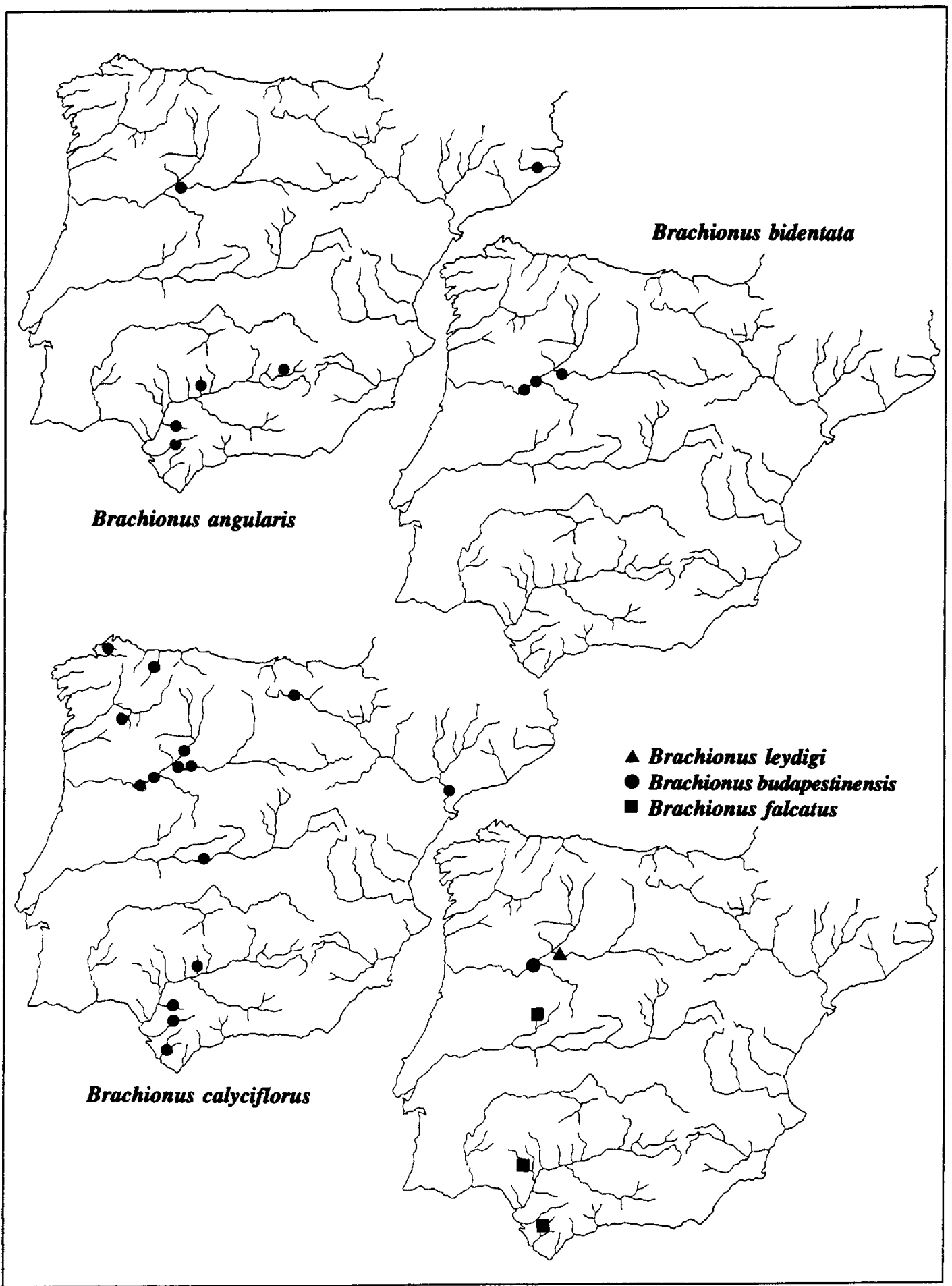

Figure 2. Distribution of some species of the genus Brachionus in Spanish reservoirs (survey 87/88). Distribución de algunas especies del género Brachionus en los embalses españoles (estudio 87/88). 
Geographical distribution. Cosmopolite. It is common in the whole of the Iberian peninsula.

Distribution in reservoirs. In last survey this species was found in plankton samples from only four southern reservoirs, but in the 1972/75 survey it was collected in 28 samples from 18 localities.

\section{Genus Brachionus (Pallas)}

Brachionus angularis (Gosse, 1951) (Fig. 2) (Fig 3,o)

Brachionus angularis angularis Koste, 1978.

Ecology. Planktonic species, common in superficial water. It can also be found in the littoral zone, among macrophytes. Euriterm, eurihaline and perennial. It presents its maximum in spring and autumn. It feeds on bacteria and detritus (Boon \& Shiel, 1990), as well as on some algae groups (Pourriot, 1977) such as chlorococcales, volvocales, euglenales and central diatoms.

Cond: $169-3720 \mu \mathrm{S} \mathrm{cm}^{-1}$; Alk: 1157.2-3038 peq $\mathrm{I}^{-1}$; $\mathrm{pH}$ : 7.7-9; Temp: $10.2-26.1{ }^{\circ} \mathrm{C}$

Morphological features of interest. It presents a great variability in size and shape. The dorsal plate of the lorica is considerably variable. Eggs are carried joined to the opening of the foot.

Geographical distribution. Cosmopolite. In Spain it has been found in numerous and widespread localities. Arévalo (1918, 1923) and Margalef (1948a) reported the presence of the taxon $B$. angularis $f$. bidens (Plate, 1886), characterized by the form of the lorica in the opening of the foot.

Distribution in reservoirs. In the most recent survey it has been found in six reservoirs (in 5 during the stratification period and in 1 during the mixing period). It was specially abundant in Guadalén (62).

Brachionus bidentata (Anderson, 1889) (Fig. 2)(Fig. 3, k)

Brachionus bidentatus Kertesz, 1894; Brachionus furculatus Thorpe, 1891.

- Ecology. Planktonic species, prefers small waterbodies. Pourriot (1974) describes the elongation of the spines induced by the presence of the predator rotifer Asplanchna brightwelli. It feeds on Polytoma, Chlorella and Chlamidomonas (Braioni \& Gelmini, 1983).

Cond: $262-300 \mu \mathrm{S} \mathrm{cm}^{-1}$; Alk: $2103-2213$ peq $^{1^{-1} \text {; }}$ pH: 7.5-7.8; Temp: 7.7-10.8 ${ }^{\circ} \mathrm{C}$

Morphological features of interest. It may be distinguished by the presence of lateral spines that are longer than the rest of spines. It is one of the most polimorphyc species and several morphs have been described (B. b.f inermis; B. b.f crassispeineus; B. b.f testudinarius; B. b. fjirovci; $B$. b. f minor).

Geographical distribution. Cosmopolite. In Spain it has been recorded only occasionally. The morph B. b. f inermis (Rousselet, 1906) has frequently been found in littoral ponds from Cartagena (unpublished data from the author). $B$. b. f. testudinarius (Jakubsky, 1912) has not been found in the Iberian peninsula, but was collected in turbid temporary ponds from Menorca and Mallorca (De Manuel et al., 1992).

Distribution in reservoirs. In last survey presence was first detected in mainland reservoirs. The morph B. b.f. crassispineus (Hauer, 1963) has been found in 3 reservoirs: Villalcampo (26), Aldeadàvila (29) and Saucelle (30).

Brachionus budupestinensis Daday, 1885 (Fig. 2) (Fig. 3,j)

Brachionus lineatus Skorikov, 1896; Brachionus punctatus Hempel 1896; Brachionus similis Leissing 1914.

Ecology. Species associared to high $\mathrm{pH}$ waters. Warm stenoterm. It tolerates moderate saline conditions. This species may be found in runing waters.

Cond: $541 \mu \mathrm{S} \mathrm{cm}^{-1}$; Alk: 3038 peq $1^{-1}$; pH: 8.1; Temp: $24.3{ }^{\circ} \mathrm{C}$

Morphological features of interest. Lorica without caudal spines. Ornamentation and variable disposition of dorsal facets. Its size is very constant.

Geographical distribution. Cosmopolite. More commonly found in tropical and subtropical regions. In the Iberian peninsula it has previously been found by Guisande \& Toja (1988) in the estuary of the river Guadalquivir. It has also been 
collected in samples from small waterbodies near the coast of Cartagena (unpublished data from the author).

Distribution in reservoirs. Its presence in Villalcampo (26) is first reported in this study.

\section{Brachionus calyciflorus Pallas 1766 (Fig. 2)} (Fig. 3,d-g)

Brachionus pala Ehremberg, 1838.

Ecology. Planktonic species; common. Occasional in runing water. Euritherm in eutrophic water. Often abundant in small eutrophic waterbodies. Very tolerant of high chloride concentrations. Filtrer-feeding, it feeds on bacteria and detritus, chlorococcales, volvocales and euglenales (Pourriot, 1977).

Cond: $22-3720 \mu \mathrm{S} \mathrm{cm}^{-1}$; Alk: $131-3667$ peq $^{-1}$; pH: 6.6-9.1; Temp: 7.7-26.1 ${ }^{\circ} \mathrm{C}$

Morphologicalfeatures of interest. Soft, sackshaped lorica, with four anterior spines. Very polymorphic species in shape and size. Some morphotypes have been described:

B. c. f. dorcas (Gosse) (Fig 3, g) with a rounded posterior margin of the lorica and medial anterior spines longer than lateral spines.

B. c. f. amphiceros (Ehrenberg) (Fig 3, d-f) with postero-lateral spines of variable size. It presents spines on the opening of the foot.

The taxonomic value of these morphs are discussed, as some variability may be phenotypic and brought about by environmental factors. Gilbert (1967) found a positive influence on the development of posterior spines in the presence of the predator Asplanchna, interpreting the larger spines as a mechanism for mechanical defense. Posteriorly, Stemberger (1990) found an important relationship between the size of spines, the size of the lorica and the presence of Asplanchna and available food.

Geographical distribution. Cosmopolite. It is widespread throughout all the Iberian peninsula.

Distribution in reservoirs. In the recent study it has been found in 17 reservoirs, 13 in the stratification period and seven after mixing. In the previous study the species had been found in 28 reservoirs, preferentially in the basins of river Duero and river Tajo.
Brachionus falcatus Zacharias 1898 (Fig.

2)(Fig. 3,i)

Ecology. Planktonic species, termophilus. Autoecology is largely inknow.

Cond: 48-1423.5 $\mu \mathrm{S} \mathrm{cm}^{-1}$; Alk:266-2002 peq l-1; pH: 8.1-8.6; Temp: $23.6-25.5^{\circ} \mathrm{C}$

Morphological features of interest. It presents six spines on the anterior dorsal margin. Intermedial spines detach by their length. Body ended by two long caudal spines, widely separated at their base. Relatively low variability in size and shape, with spines always well developed.

Geographical distribution. Pantropical and pansubtropical. Widely distributed in subtropical regions, especially in South-America. De Ridder (1981) contends that this species is clearly in geographical expansion. In the Iberian Peninsula it has been found occasionally (Monteiro, 1984; Guisande \& Toja,1988). It has been found in a small waterbody in Extremadura ("charca de Berrueco", unpublished data from the author).

Distribution in reservoirs. An abundant population was found in summer samples from Bornos (87). Some specimens were collected in $\mathrm{La}$ Minilla (84) and Borbollón (45).

Brachionus leydigi Cohn, 1862 (Fig. 2)(Fig. $3, \mathrm{~h})$

Brachionus quadratus var. tridentatus (Zernov, 1901).

Ecology. Heleoplanktonic species, cold stenoterm. More frequent in small waterbodies, it tolerates relatively high salinity.

Cond: $262 \mu \mathrm{S} \mathrm{cm}^{-1}$; Alk: 2103 peq $\mathrm{l}^{-1}$; pH: 7.5; Temp: $7.7^{\circ} \mathrm{C}$

Morphological features of interest. The basal plate of the lorica presents a distinctive medial crest. The most characteristic feature of this species is the presence of three spines on the opening of the foot. Resting eggs with short and wide spines. B. leydigi is very polymorphic, Ahlstrom (1940) remarks the variability of the foot opening, as well as the morphology of the three spines.

Geographical distribution. Cosmopolite. In the Iberian peninsula it has been recorded in the estuary of the river Guadalquivir (Guisande \& 


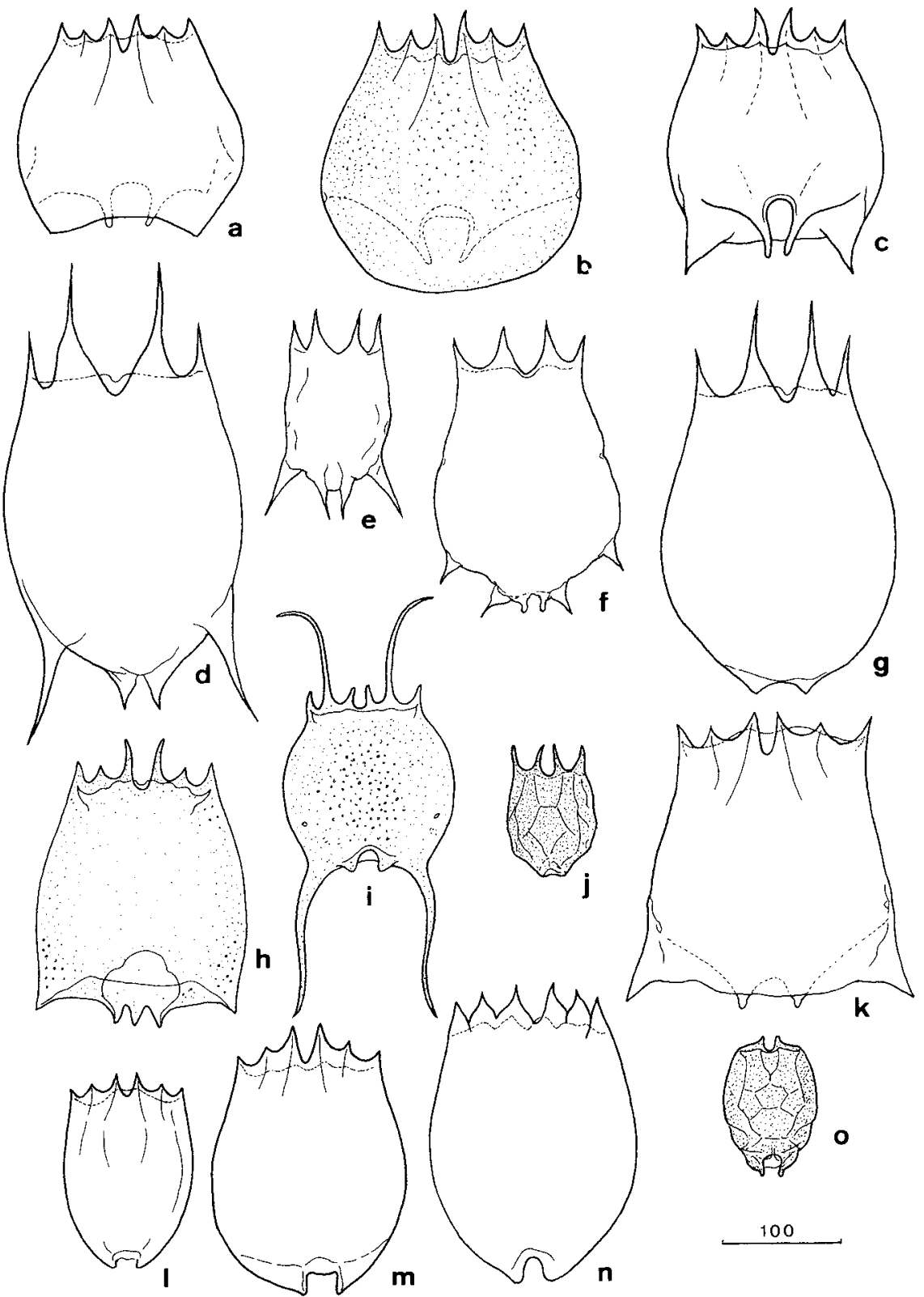

Figure 3. Taxa of the genus Brachionus found during the $87 / 88$ survey of the Spanish reservoirs. Scale in $\mu \mathrm{m} . \mathrm{a}, \mathrm{b}, \mathrm{c}$, Brachionus quadridentatus Hermann: a, b, f. cluniorbicularis (Skorikov),from San Román and from Saucelle respectively; c, f. brevispinus Ehrenberg, from Sobrón; d, e, f, g, B. calyciflorus Pallas: d-f. f. amphiceros from Flix (d) and from San Román (e, f); g, f. dorcas Gosse, from Bornos; $h, B$. levdigi Cohn, from Villalcampo; $\mathrm{i}$, B. falcatus Zacharias, from Bornos; $\mathrm{j}$, B. budapestinensis Daday, from Villalcampo; $\mathrm{k}$, B. bidentataf. crassispineus (Hauer), from Villalcampo; $1, \mathrm{~m}, B$. urceolaris Müller, from Villałcampo and from Aldeávila, respectively; $\mathrm{n}, B$. plicatilis Müller, from Puentes; o, B. angularis (Gosse), from Bornos. Taxones del género Brachionus encontrados en los embalses españoles (estudio 87/88). $a, b, c$, Brachionus quadridentatus Hermann: $a, b$, f. cluniorbicularis (Skorikov), de San Román y de Saucelle respectivamente; $c, f$. brevispinus Ehrenberg, de Sobrón; d, e, f, g, B. calyciflorus Pallas: d-f. f. amphiceros de Flix (d) y de San Romän (e, f); g, f. dorcas Gosse, de Bornos; $h$, B. leydigi Cohn, de Villalcampo; $i$, B. falcatus Zacharias, de Bornos; $j$, B. budapestinensis Daday, de Villalcampo; $k$, B. bidentata f. crassispineus (Hauer), de Villalcampo; $l, m$, B. urceolaris Müller, de Villalcampo y de Aldeávila respectivamente; $n$, B. plicatilis Müller, de Puentes; $\boldsymbol{o}$, B. angularis (Gosse), de Bornos. 
Toja, 1988). However, this species has a northern distribution. In the river Duero basin, for instance it has been collected in several reservoirs and also in Villafáfila ponds (unpublished data from the author).

Distribution in reservoirs. In the 1987-88 survey $B$. leydigi was found in Villalcampo (26), in the river Duero basin. In the earlier survey in addition it was recorded in Aldeadàvila (29), located in the same basin.

Brachionus plicatilis Müller 1786 (Fig. 3,n)

Brachionus mulleri Ehrenberg 1834; Brachionus hepatolomeus Gosse 1851; Brachionus spatiosus Rousselet, 1912; Brachionus orientalis Rodewald, 1937.

Ecology. Planktonic and polithermic species. Inhabits waterbodies with a wide range of salinity $\left(1 \mathrm{~g}^{-1}-97 \mathrm{~g} \mathrm{l}^{-1}\right)$. Tolerates also low oxygen concentrations (Esparcia et al., 1989). Dense populations are frequently seen, probably because no rotifers or other filter-feeding organisms can compete in highly saline conditions. Filterer and poliphagus; it feeds on organic dretritus, bacteria, chlorococcals, volvocales, euglenales, cryptomonadacea, cyanophita and also rhodophita (Porphiridium). It is probably the most investigated rotifer, and its ecology is well

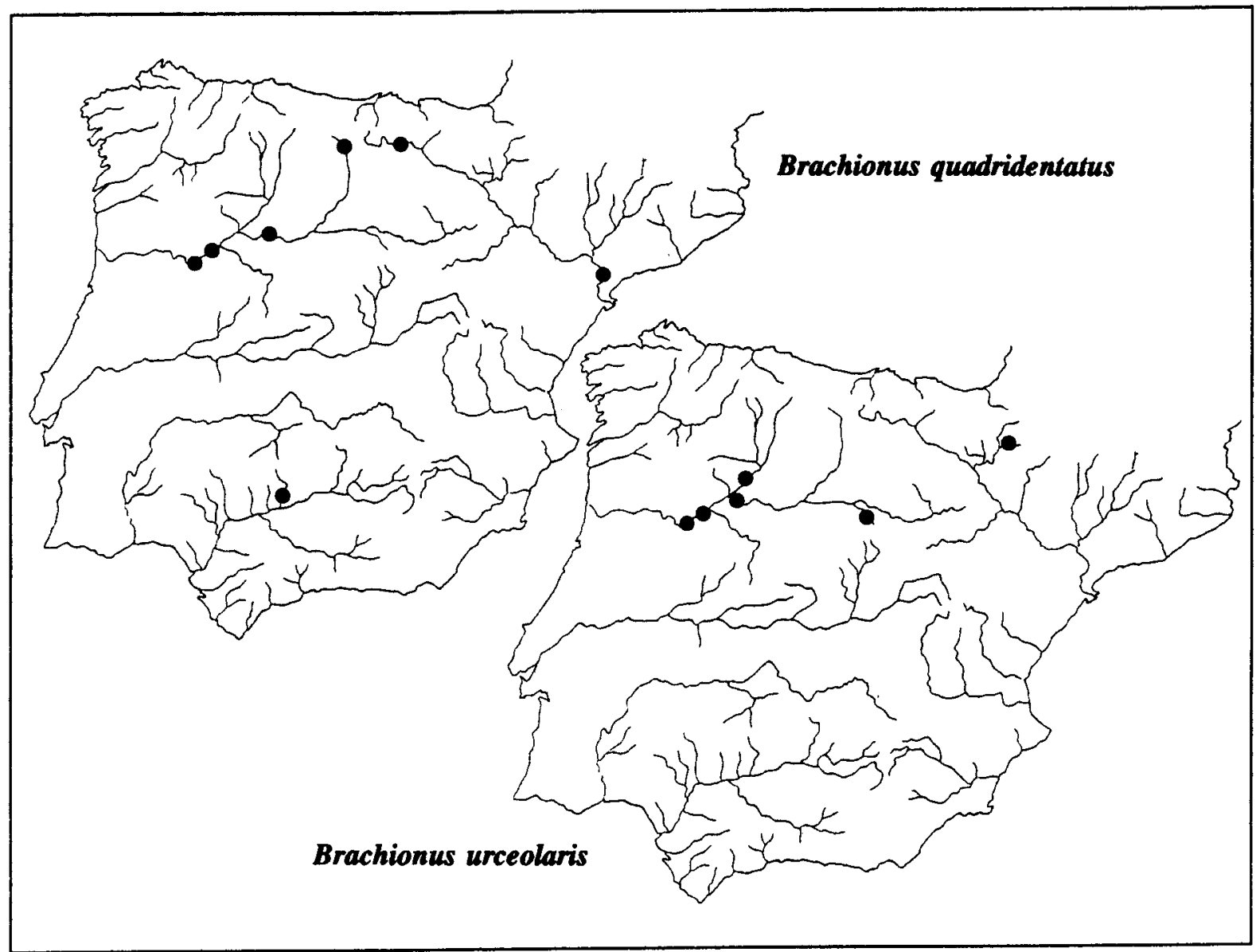

Figure 4. Distribution of B. quadridentatus and B. urceolaris in Spanish reservoirs (survey 87/88). Distribución de B. quadridentatus y B urceolaris en los embalses españoles (estudio $87 / 88$ ). 
known (Walker, 1981). It is relatively easy to culture and in the last decades it has acquired great importance for aquiculture and research. It is importance has been extended fields as genetics and evolution (King \& Snell, 1977: Snell \& Hawkinson, 1983; King, 1989; among others).

Cond: $1423-3720 \mu \mathrm{S} \mathrm{cm}^{-1}$; Alk:1455-1927 $\mu \mathrm{eq} \mathrm{l}^{-}$ '; pH: 8.2-8.5; Temp: $19.3-26^{\circ} \mathrm{C}$

Morphological features of interest. The lorica is relatively soft and flexible. The species is characterized by the presence of four lobules in the anterior ventral plate. It presents a notable sexual dimorphism. There are many morphotypes of this species (Sudzuki, 1987; Koste 1980b).

Geographical distribution. Cosmopolite. In Iberian peninsula it has been collected in coastal ponds and endorheic ponds with high or moderate salinity. Serra \& Miracle (1983) and Serra (I 987) have studied the variability of this species across a range of environments found in the Iberian peninsula.

Distribution in reservoirs. It has been found in summer samples from three southern reservoirs: Puentes (77), Torre del Aguila (86) and Bornos (87). It was not found in previous surveys.

Brachionus quadridentatus Hermann, 1783 (Fig. 3,a-c)

Brachionus capsuliflorus Pallas, 1766; Brachionus bakeri Muller, 1786. Brachionus brevispinus Ehrenberg, 1832; Brachionus cluniorbicularis Skorikov, 1894.

Ecology. Heloplanktonic species. Common in small waterbodies and also in current waters. It prefers alkaline water. Eurihaline, it may live in moderate saline water.

Cond: $197.2-765.5 \mu \mathrm{S} \mathrm{cm}^{-1}$; Alk: $1679-3545.5$ $\mu$ eq $\mathrm{l}^{-1}$; $\mathrm{pH}$ : 8.1-9.1: Temp: $16.3-24^{\circ} \mathrm{C}$

Morphological features of interest. The lorica normally ends in the posterior part in two lateral spines of variable length. It is a very variable species, Its posterior spines have negative allometric growth.

Geographical distribution. Cosmopolite, it is maybe the most common species of the genus Brachionus.

Distribution in reservoirs. Only the morphs
B. f. cluniorbicularis (Skorikov, 1894) and $B$. f. brevispinus (Ehrenberg, 1832) have been collected in seven reservoirs located in the northern area of the Iberian peninsula and only during the summer (Fig. 4).

Brachionus urceolaris Muller, 1773 (Fig. 3,m)

Tubipora urceus Linnaeus, 1758; Brachionus nicaraguensis, Schmarda, 1859; Brachionus pyriformis, Barrois \& Daday, 1894.

Ecology. Mainly heleoplanktonic species, common in alkaline small waterbodies. Eurihaline, it tolerates relatively high salinity. It has been found in current waters.

Cond: $161.5-541 \mu \mathrm{S} \mathrm{cm}^{-1}$; Alk 618-3038 peq $\mathrm{l}^{-1}$; pH: 7.25-9; Temp: 7.35-24.3 ${ }^{\circ} \mathrm{C}$

Morphological features of interest. Dorsal anterior spines above a small basis. It presents an approximately rectangular dorsal opening of the foot. Ventral opening with semicircular shape. As other species of the genus, it has a great plasticity and presents abundant morphs and variability of size.

Geographical distribution. Cosmopolite. It has been collected throughout the Iberian peninsula.

Distribution in reservoirs. It has been identified in six reservoirs (Fig. 4), five belonging to the basin of the river Duero, preferentially during the mixing period. The distribution of this species found here is very similar to the distribution found in the previous study.

\section{Genus Keratella Bory de St. Vincent}

Keratella cochlearis (Gosse, 1851) (Fig. 5 a-f) (Fig. 6 b)

Anuraea cochlearis Gosse, 1851; Anuraea longispina Imhof, 1883; Anuraea intermedia, Imhof, 1885.

Ecology. Euplanktonic species. Very common in lakes and reservoirs, but uncommon in small waterbodies. Eurithermic, it tolerates a wide range of mineralization. It feeds on a great variety of algae as well as organic detritus and bacteria (Pourriot, 1965, 1977; Boon \& Shiel, 1990). It is one of the most abundant prey found in the stomach of Asplanchna and Ploesoma (Guiset, 
1977c). Some variables as temperature, food availability, as well the presence of predators, determine different morphs (Stemberguer \& Gilbert, 1984), sometimes described as separate species. It also presents seasonal variations in morphology.

(f. typica) Cond: $14.7-5326 \mu \mathrm{S} \mathrm{cm}^{-1}$; Alk: 58 4681 peq $\mathrm{I}^{-1}$; pH: 6.3-10.1; Temp: $6-26.7^{\circ} \mathrm{C}$

(f. tecta) Cond: $22-5326 \mu \mathrm{S} \mathrm{cm}{ }^{-1}$; Alk: $131-$ $3882 \mu$ eq $\mathrm{I}^{-1}$; pH: 6.6-10.2; Temp: $6-26.7^{\circ} \mathrm{C}$

Morphological features of interest. It presents polymorphism in the size of the lorica and in the length of the caudal spine. Numerous varieties have been described, but controversy exists about the phenotypic or genotypic origin of differences. The distinction among morphs is based on the length of the caudal spine and on the size of the lorica:

$K$. cochlearis f. macracantha (Lauterborn, 1898) (Fig. 5 a), with a long caudal spine (80 $110 \mu \mathrm{m})$.

K. cochlearis f. tecta (Gosse, 1851) (Fig. 5 e). Spineless morph. It constitutes the most smallest morph of the series. Koste \& Shiel (1987b) considered this taxon as species (based on the first description of Anuraea tecta,Gosse, 1851).

$K$. cochlearis $f$. micracantha (Lauterborn, 1900) (Fig 5 c,d). Characterized by a shorter spine than the typica morph. It is an intermediate stadium between the typical form and the spineless one.

K. cochlearis var. hispida (Lauterborn, 1898) (Fig. 5 f), with a wider lorica than the tipica morph, it is covered by small protuberances ("hair"), contrasting with the areolated ornamentation of other taxa of the series. The caudal spine is relatively short (Koste \& Shiel, 1987b, confers it species category).

K. cochlearis var. robusta (Lauterborn, 1900). (Fig. 5 b). Lorica bigger than the typica morph. The caudal spine is generally long.

Geographical distribution. Cosmopolite. It is probably the most common rotifer and is widespread throughout the world (Ahlstrom, 1943). It is found across the whole Iberian peninsula, but its presence has not been detected in the Balearic archipelago (De Manuel et al., 1992).
Distribution in reservoirs. It is found in most Spanish reservoirs. It is more frequent and abundant during the stratification period. K. var. hispida, (Fig. 4. f) has been found in Urrunaga (4), and it is the first record of this taxon in Spain.

Keratella irregularis (Muller, 1786) (Fig. 5 g-i and Fig $6 \mathrm{c}$ )

Anuraea cochlearis var. irregularis Lauterborn, 1898 .

Some autrors (Carlin, 1943; Ruttner-Kolisko, 1974; Koste, 1978) considers it as a variety of $K$. cochlearis. Ahlstrom (1945), Kutikova (1970) and Pejler (1977), among others, relates it as $K$. irregularis, with species category.

Ecology. Euplanktonic species. Warm stenoterm. It is highly seasonal, occurring in late spring, with a maximum in summer and a fall in abundance in early autumn.

Cond: $19.6-808 \mu \mathrm{S} \mathrm{cm}^{-1}$; Alk: 116.8-3545.5 peq $\mathrm{l}^{-1}$; pH: 7-9.9; Temp: $15.9-24.8^{\circ} \mathrm{C}$

Morphological features of interest. Very similar to $K$. cochlearis. Differences should be found in the dorsal morphology of the lorica. The distinctive character is the presence of a small medial plaque of pentagonal shape, slightly in the right, between carinal plaques (Fig. 6 c). Nipkow (1961) also found differences between the size and shape of resting eggs of $K$. cochlearis and $K$. irregularis.

Geographical distribution. Cosmopolite. Probably it has frequently been confused with $K$. cochlearis. For this reason, $K$. irregularis is not recorded in the checklist of Velasco (1990).

Distribution in reservoirs. It follows a latitudinal distribution. It is present in summer samples in northern reservoirs (Fig. 9). In the last study it has been identified during the stratified period in approximately $25 \%$ of reservoirs. In the previous study it was also found in summer, in $9 \%$ of Spanish reservoirs, as well in northern regions.

Keratella quadrata (Muller, 1786) (Fig. 7 a,b)

Brachionus quadratus Muller, 1786; Anuraea aculeata Erhenberg, 1832; Keratella quadrata after Bory de St. Vincent, 1822.

Ecology. Euplanktonic species. Perennial, it is not seasonal. It has a wide range of tolerance to 

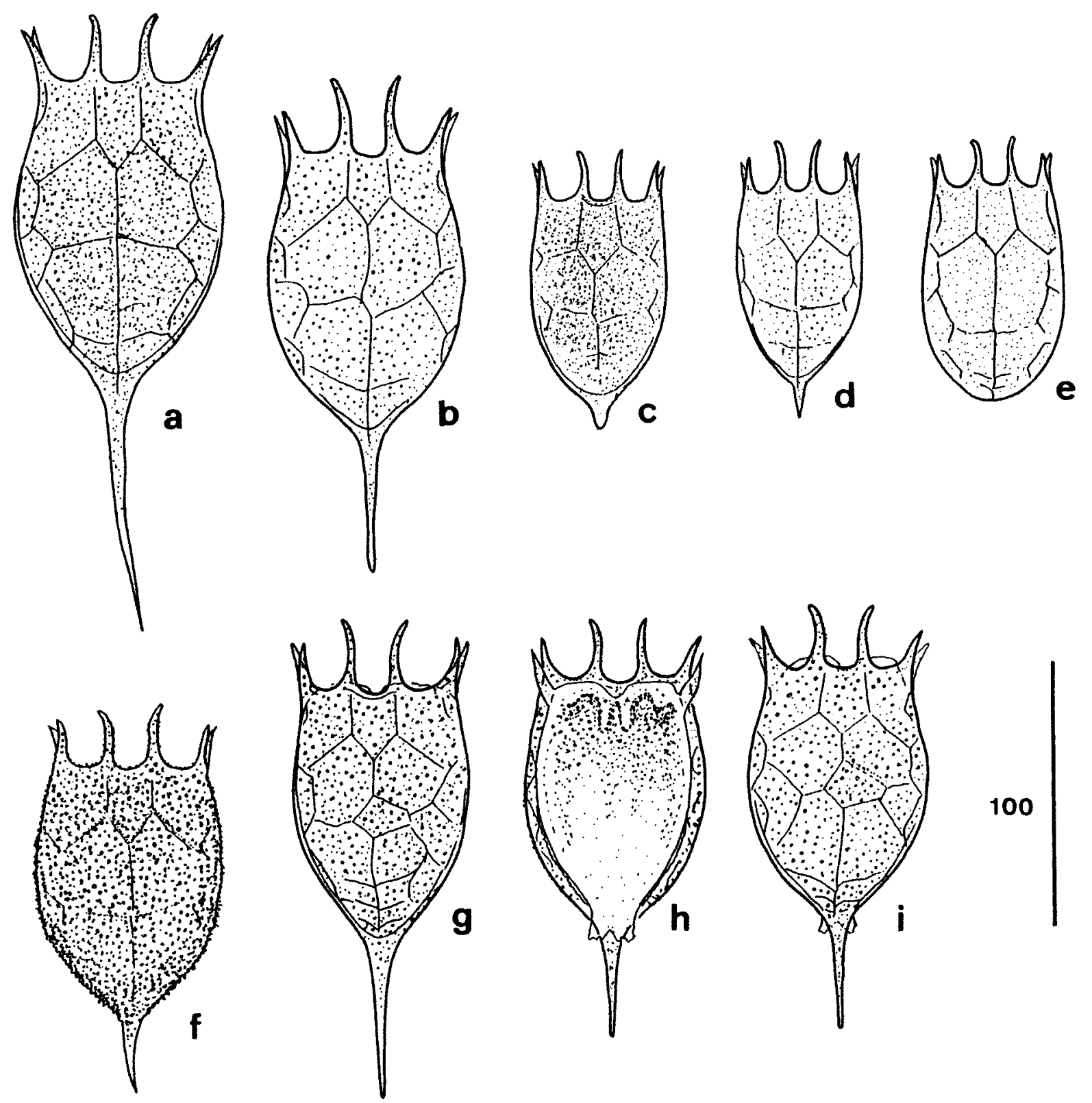

100

Figure 5. Some taxa of the genus Keratella found in Spanish reservoirs. Scale in $\mu \mathrm{m}$. a-f. Keratella cochlearis (Gosse): a, f. macracantha from Fervenza; b, var. robusta from Frieira; c, d, f. micracantha from Bornos and from Riudecanyes, respectively; e, $f$. tecta from Riudecanyes; f, var. hispida from Urrunaga; g-i, K. irregularis (Lauterborn): g, from Sant Ponç; h, and, ventral and dorsal plate of the same species but from Salime. Algunos taxones del género Keratella encontrados en embalses españoles. Escala en um. a a-f. Keratella cochlearis (Gosse): a, f. macracantha de Fervenza; $b$, var. robusta de Frieira; $c, d, f$. micracantha de Bornos y de Riudecanyes respectivamente; $e$, f. tecta de Riudecanyes; $f$, var. hispida de Urrunaga; $g-i, \mathrm{~K}$. irregularis (Lauterborn): $g$, de Sant Ponç; $h, y$, placas ventral y dorsal de la misma especie pero de Salime. 


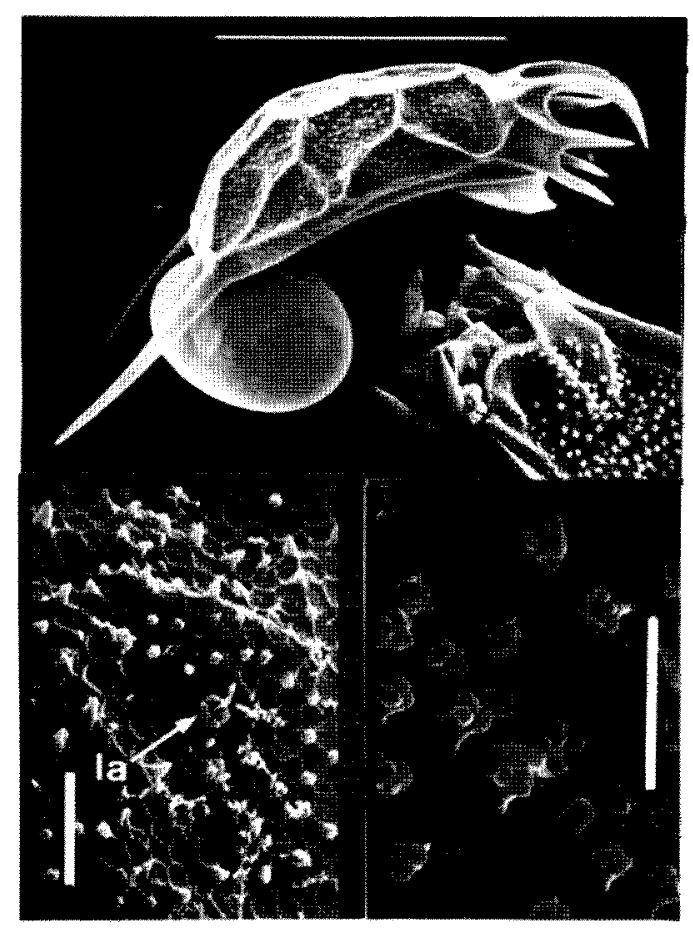

A

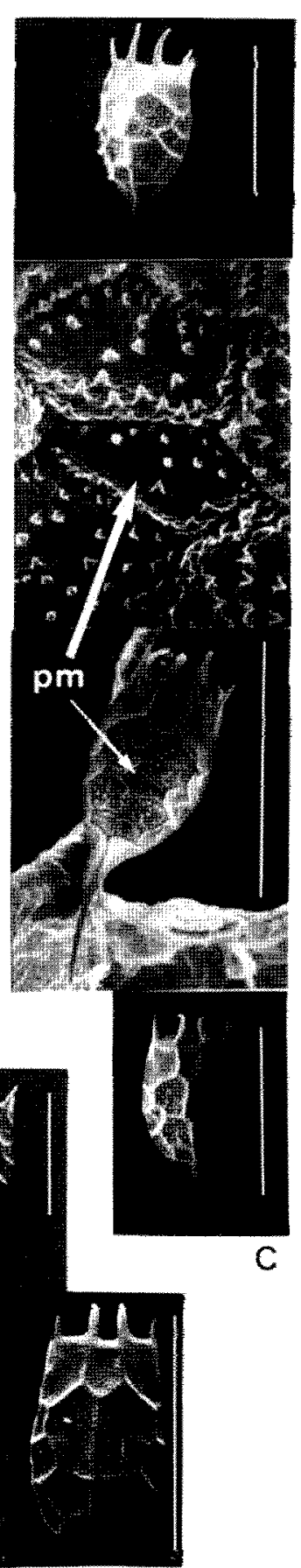

Figure 6. SEM photographs of some taxa of the genus Keratella in Spanish reservoirs. Scale bar is $100 \mu \mathrm{m}$ (except for microestructures for which the scale bar is $5 \mathrm{~mm}$ ). a. Keratella quadrata (Müller): female carrying an egg, ventral lorica; lateral antenae (la); granulation of the anterior ventral lorica. B. K. cochlearis (Gosse): f. tecta and f. typica. C. K. irregularis (Lauterborn): accessory median plate (pm). Fotografias MES de algunos taxones del género Keratella identificados en embalses españoles. la barra indica una escala de loo um (excepto para microestructuras en que esta es de $5 \mathrm{~mm}$ ). a. Keratella quadrata (Müller): hembra llevando un huevo, loriga ventral; antena lateral (la); granulación de la loriga ventral anterior. b. K. cochlearis (Gosse): f. tecta y f. typica. c. K. irregularis (Lauterborn): placa accesoria media (pm). 

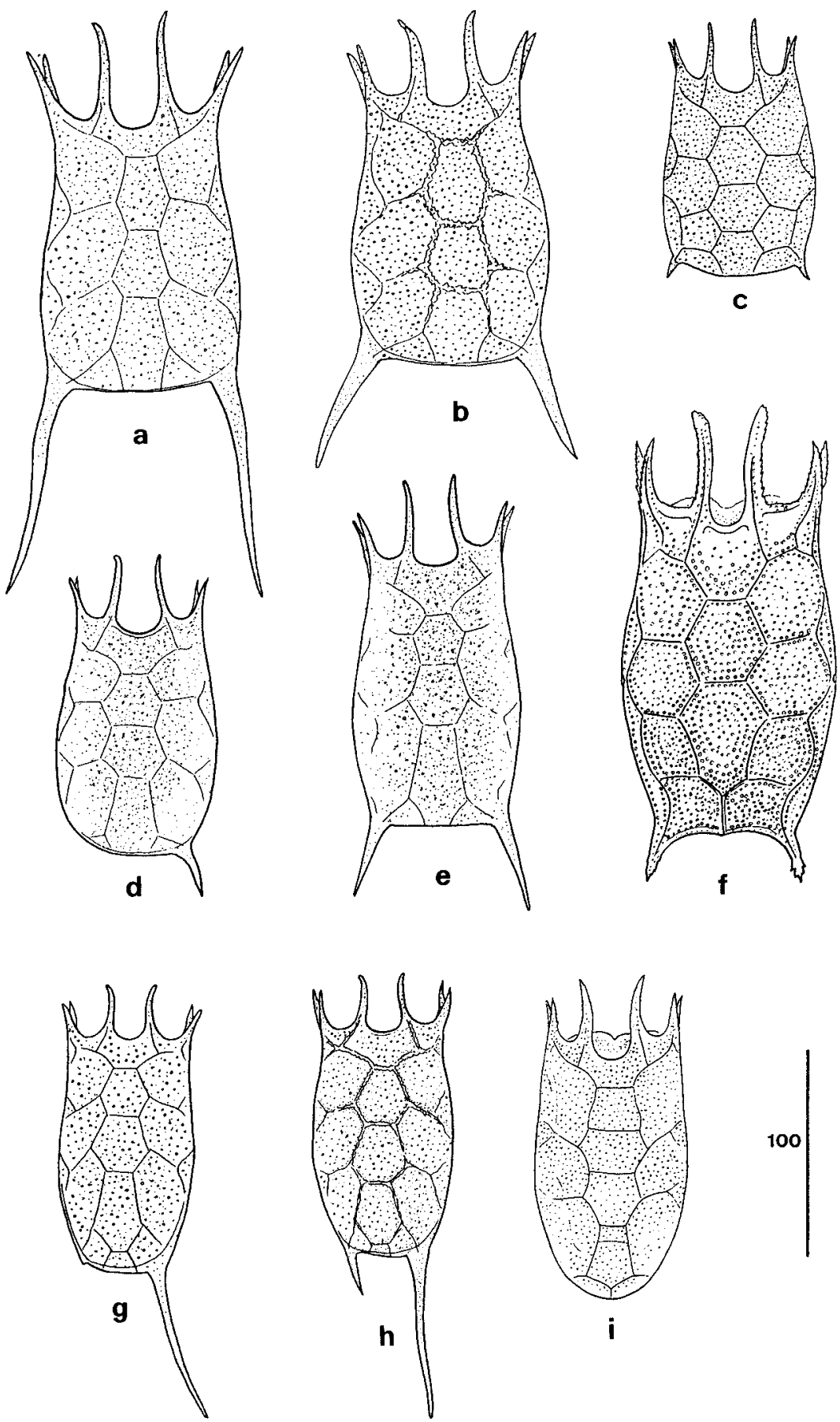

Figure 7. Some taxa of the genus Keratella in Spanish reservoirs. Scale in $\mu \mathrm{m}$. a, b, Keratella quadrata (Müller), from Breña and from Susqueda, respectively; c, K. testudo (Ehrenberg), from Frieira; d, e, K. valga (Ehrenberg), from Frieira and As Conxas, respectively; f, K. serrulata (Ehrenberg) from Mao; g, h, K. tropica (Apstein), from Flix and from Bornos, respectively; and, i K. ticinensis (Callerio), from Frieira. Algunos taxones del género Keratella recolectados en embalses españoles. Escala en $\mu m$. a, b. Keratella quadrata (Müller), de La Breña y de Susqueda respectivamente; $c, \mathrm{~K}$. testudo (Ehrenberg), de Frieira; $d, \boldsymbol{e}, \mathbf{K}$. valga (Ehrenberg), de Frieira y As Conxas respectivamente $f, \mathbf{K}$. serrulata (Ehrenberg) de Mao; $g, h, \mathrm{~K}$. tropica (Apstein), de Flix y de Bornos respectivamente; $y, i \mathrm{~K}$. ticinensis (Callerio), de Frieira. 
mineralization and temperature. Poliphagous, it feeds on organic detritus and bacteria, chlorococcales, volvocales, euglenales, chrysophyceae and central diatoms (Pourriot, 1977).

Cond: $19.6-5326.6 \mu \mathrm{S} \mathrm{cm}{ }^{-1}$; Alk: $98-4681.7$ $\mu$ eq $\mathrm{I}^{-1}$; $\mathrm{pH}$ : 6.64-10.18 ; Temp: $6.4-26.1^{\circ} \mathrm{C}$

Morphological features of interest. Lorica generally almost rectangular; posteromedial plaque is hexagonal. Two caudal spines inserted at posterolateral corners of the lorica. Extremely polymorphic in size and also in the length of the caudal spines. Lorica surface with strong granulation. Mictic females, which produce resting eggs, usually present longer caudal spines, which are progressively reduced in successive generations (Ahlstrom, 1943). K. quadrata presents an alometric relationship between the caudal spines and the lorica (Margalef, 1948a; Pejler, 1962; Miracle, 1976; Guiset, 1977b).

Geographical distribution. Cosmopolite. Widely distributed across the Iberian peninsula.

Distribution in reservoirs. Very common in reservoirs $(72 \%)$, but generally with not very abundant populations.

Keratella serrulata (Ehrenberg, 1838) (Fig. 7 f) (Fig. 8 a)

Anuraea serrulata Ehrenberg, 1838; Keratella falculata Ehrenberg, 1838; Keratella serrulata after Harring, 1913.

Ecology. According to Berzins \& Pejler (1987), it is the only planktonic brachionidae specialist from acid waters. Common in acid water from bogs with Sphagnum. It feeds on chrysophyceae and volvocales (Pourriot, 1977).

Cond: $22 \mu \mathrm{S} \mathrm{cm}^{-1}$; Alk: 131 peq $\mathrm{l}^{-1}$; $\mathrm{pH}$ : 6.6; Temp: $18.6^{\circ} \mathrm{C}$

Morphologicalfeatures of interest. Robust lorica, granulated or covered by short spines or granules. Anterior spines on margins are slightly serrated (Fig. 8.a). Posterior lateral corners of lorica with spines of variable length or spineless. Systematic diagnosis of the species is on the absence of the posteromedial plaque and the presence of a median line separating posterocarinal plaques. K. serrulata may be confused, by disposition of its plaques, with the species Keratella procurva (Thorpe, 1891), which is smaller and with a lorica not robust. The latter species inhabits more alkaline waters.

Geographical distribution. Cosmopolite. It is not found in tropical regions. In the Iberian peninsula it has been collected in NW reservoirs (Margalef, 1955).

Distribution in reservoirs. It has been found in reservoirs from Galicia, NW. Spain (Fig. 9). It has also been collected in a recent study in Mao (99), a reservoir characterized by a low conductivity $\left(19.75 \mathrm{mS} \mathrm{cm}^{-2}\right)$ and relatively acid $\mathrm{pH}$ (i.e. 6.83) and in Ribeira (14).

Keratella testudo (Ehrenberg, 1832) (Fig. 7 c)

Anuraea testudo Ehrenberg, 1832; Anuraea aculeata brevispina Weber, 1898; Anuraea brevispina, Gosse, 1851; Keratella quadrata brevispina, Edmondson \& Hutchinson, 1934.

Ecology. Planktonic species. Mostly in small waterbodies. According Sladecek (1983) it feeds on bacteria, organic detritus, chlorococals, euglenales, cryptomonadaceae, chrysophyceae and diatoms.

Cond: $50-81 \mu \mathrm{S} \mathrm{cm}^{-1}$; Alk: 242-447.6 peq 1-1 $\mathrm{pH}$ : 7.15-7.2; Temp: $10.2-18.9^{\circ} \mathrm{C}$

Morphological features of interest. Trapezoidal lorica with a rounded posterior margin. Posterior spines very short, asymmetric and slightly divergent. The left-postero spine may be shorter than the right spine. It may be confused with the species $K$. quadrata, which has not two completely closed lateral facets, as $K$. testudo has (Fig. 8 b).

Geographical distribution. Cosmopolite. It is a rare species, occurring occasionally. In the Iberian peninsula it was first found by Wizniewski (1931) and Arévalo (1932); Fores et al. (1986) collected it in ponds of Delta de l'Ebre, in the NW Spanish mediterranean coast.

Distribution in reservoirs. In this survey it has been found in Frieira (97), in winter samples, in low abundance. In the previous study of reservoirs it was collected from Susqueda (80) and Aldeadàvila (29).

Keratella ticinensis (Ehrenberg, 1834) (Fig. 7 i)

Anuraea curvicornis Ehrenberg, 1834; Anuraea aculeata var. ticinensis Callerio, 1920. 


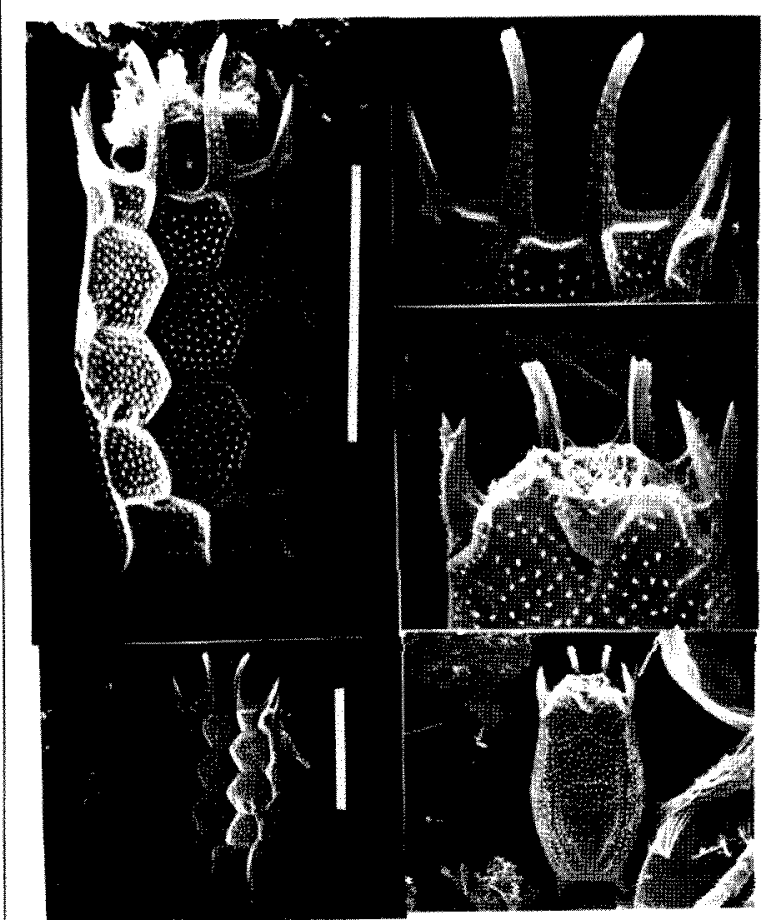

A
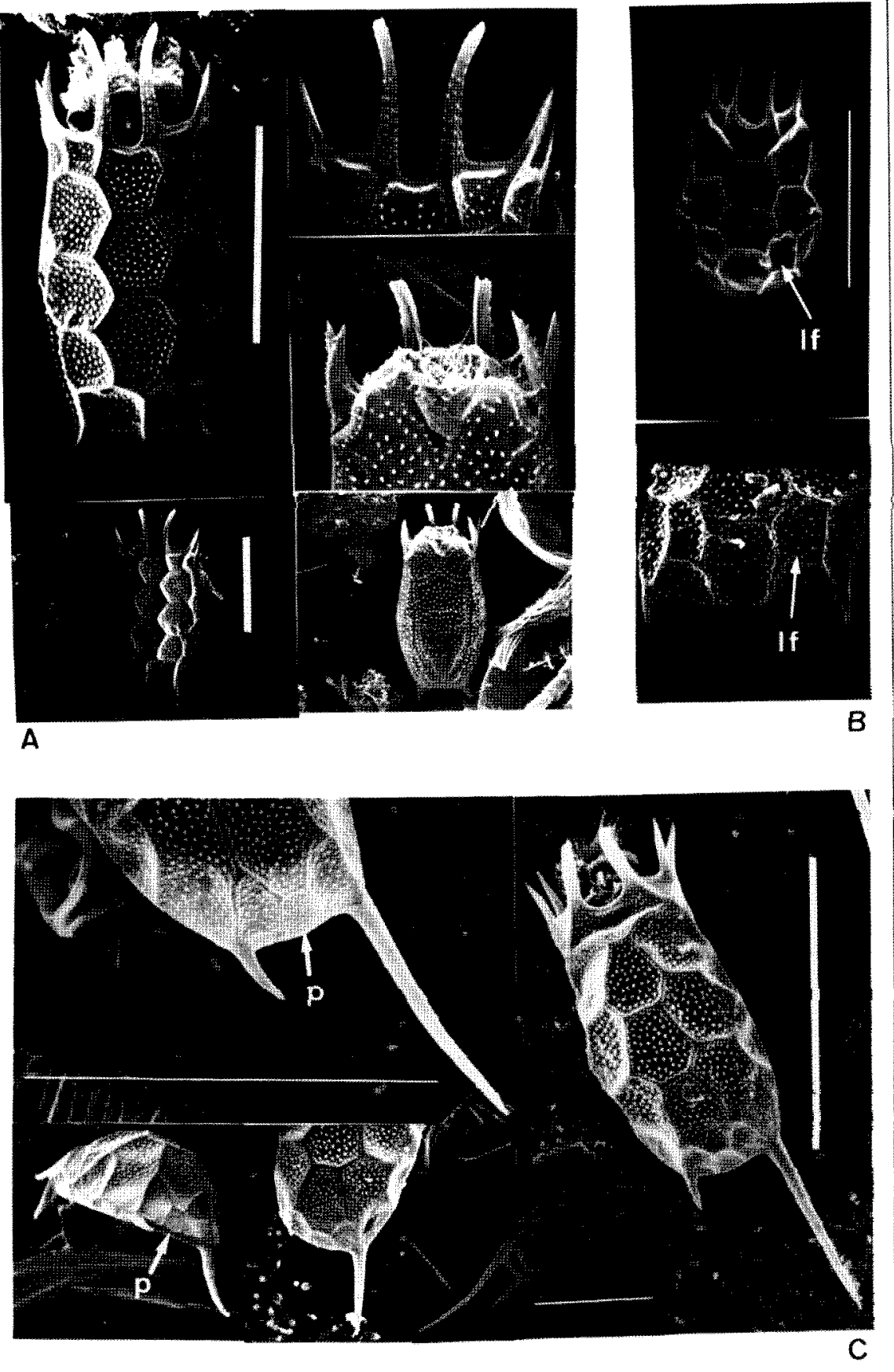

Figure 8. SEM photographs of some taxa of the genus Keratella in Spanish reservoirs. Scale bar is $100 \mu \mathrm{m}$. a. Keratella serrulata (Ehrenberg): serrated anterior spines, ornamentation of ventral lorica: b. K. testudo (Ehrenberg): lateral facets (1f) in sligthly contracted specimens); c. $K$. tropica (Apstein): different views of the lorica, i.e. posterior facet (p) to the posteriomedial facet. Fotografias MES de algunos taxones de del género Keratella de los embalses españoles. Línea de escala $100 \mu m$. a. Keratella serrulata (Ehrenberg): espinas anteriores serruladas, ornamentación de la lóriga ventral; $b . \mathrm{K}$. testudo (Ehrenberg): facetas lateraless (If) en individuos ligeramente contraidos; $c$. K. tropica (Apstein): diferentes vistas de la lórica, de faceta posterior $(p)$ a faceta posteromediana. 
Ecology. Species from ephemeral and dystrophic waterbodies (Koste, 1978). Heleoplanktonic. Ruttner-Kolisko (1974) sustained that $K$. ticinensis is a transition species between quadrata and serrulata groups.

Cond: $77 \mu \mathrm{S} \mathrm{cm}^{-1}$; Alk: $429.2 \mu \mathrm{eq} \mathrm{l}^{-1}$; $\mathrm{pH}: 7.1$; Temp: $9.6^{\circ} \mathrm{C}$

Morphological features of interest. Oval lorica, rounded and spineless posterior end. Anterior spines are relatively long. It may present small protuberances in the dorsal part of the lorica. Anteromedial plaque is approximately squared and is a diagnostic trait. May be confused with spineless morphs of $K$. cochlearis (K. c.f. tecta, Fig. 4. e), but $K$. ticinensis is bigger, and the disposition of dorsal plaques is very distinctive. Its eggs are covered by short spines with curved ends.

Geographical distribution. It is considered as a cosmopolite species, but its actual distribution is European. The population found in reservoirs are the first record of this species in the Iberian peninsula.

Distribution in reservoirs. It has been found in winter samples in a survey by Frieira (97) in Galiza; (conductivity $77 \mathrm{mS} \mathrm{cm}^{-2}$, pH 7.25).

Keratella tropica (Apstein, 1907) (Fig. 7 g,h) (Fig $8 \mathrm{c}$ )

Anuraea valga $f$. tropica Apstein, 1907. Keratella valga $f$. tropica after Edmondson and Hutchinson, 1934.

Ecology. Euplanktonic species. Warm stenoterm, preferentially in alkaline waters.

Cond: $262-1065 \mu \mathrm{S} \mathrm{cm}{ }^{-1}$; Alk: 2103-3486.5 peq $\mathrm{l}^{-1}$; pH: $8.1-8.49$; Temp: $18.5-24.5^{\circ} \mathrm{C}$

Morphological features of interest. Rectangular lorica. Posterior spines unequal, with the right spine longer than left. The last can be absent even when right spine is quite long. K. tropica has a posteromedian remnant after the postero posteromedial plaque (Fig. $8 \mathrm{c}$ ), sometimes difficult to observe. This remnant is the only feature which differences it from $K$. valga. The lengths of spines and lorica are very variable, and there is an allometric relationship between them.

Geographical distribution. Pantropical and pansubtropical. It has frequently been found in southern territories of the Iberian Peninsula, but occasionally also in northern waterbodies.

Distribution in reservoirs. It was collected in only eight reservoirs in the 72/75 survey, but in last study it has spread its distribution to 17 localities (Fig. 9).

Keratella valga (Müller, 1786) (Fig. 7 d,e)

Anuraea valga Ehrenberg, 1834; Keratella valga after Ahlstrom, 1943. There is controversy about the specific definition of $K$. valga and $K$. tropica. Alhstrom (1943) considered K. tropica as a morph of $K$. valga, Ruttner-Kolisko (1974) included $K$. valga as a morphotype of $K$. quadra$t a$. Recently, the tendency is to consider both taxa as separate species.

Ecology. Planktonic species, euriterm. Inhabits small waterbodies with low alkalinity. Feeds meanly on cryptomonadaceae and volvocales (Pourriot, 1977).

Cond: $51.5-78.3 \mu \mathrm{S} \mathrm{cm}^{-1}$; Alk: $171-439.3 \mu \mathrm{eq}$ $\mathrm{l}^{-1} ; \mathrm{pH}: 6.8-7$; Temp: $7.8-9.4{ }^{\circ} \mathrm{C}$

Morphological features of interest. Very similar to $K$. tropica. Lorica broader at anterior end. No posteromedial remnant under posteromedial plaque. Caudal spine not very long, unequal in length or only one present. Resting eggs with prickly shell.

Geographical distribution. It has only been found in the Paleartic region and Australia (Pejler, 1977). Uncommon. In the Iberian peninsula it has occasionally been found in small waterbodies (De Ridder, 1962; Arévalo, 1923) and in some reservoirs.

Distribution in reservoirs. In both surveys some specimens of $K$. Valga were occasionally found, mainly in NW reservoirs with waters of low mineralization.

\section{Genus Kellicottia Ahlstrom}

Kellicottia longispinu (Kellicott, 1879) (Fig. 11

a) (Fig. 10)

Anuraea longispinu Kellicott, 1879

Ecology. Euplanktonic species. Perennial and meanly inhabitant of oligotrophic lakes. It is not found in small waterbodies. According to 


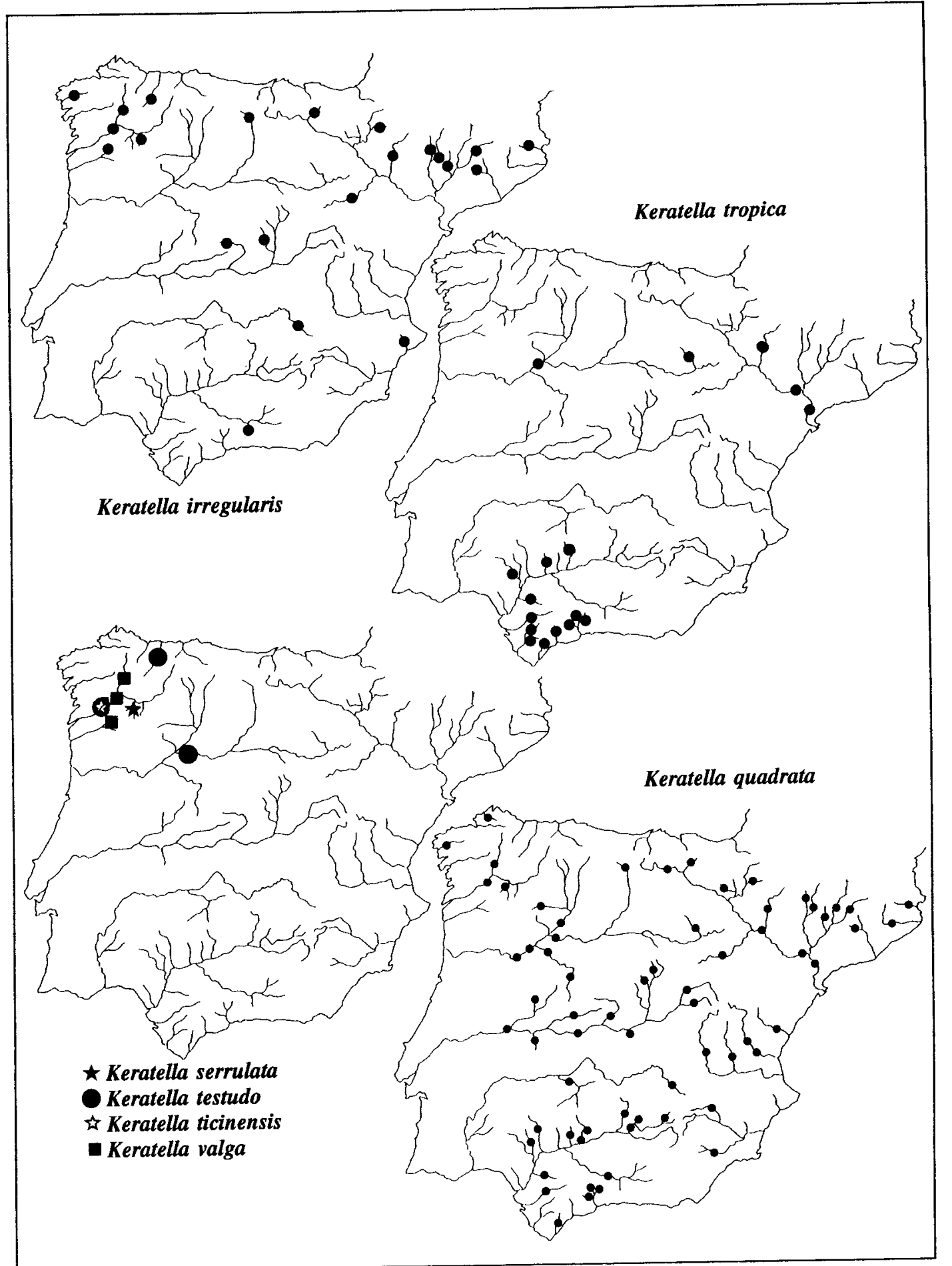

Figure 9. Distribution of some species of the genus Keratella found in Spanish reservoirs during the 87/88 survey. Distribución de algunas especies de gérero Keratella en los embalses españoles (estudio 87/88). 
Pourriot (1977) it feeds on chrysomonadals and central diatoms.

Cond: $305-322 \mu \mathrm{S} \mathrm{cm}^{-1}$; Alk: 1194-1996 $\mu \mathrm{eq} \mathrm{\textrm {I } ^ { - }}$ I; $\mathrm{pH}$ : 8.2-8.5; Temp: $10.63-21.82{ }^{\circ} \mathrm{C}$

Morphological features of interest. This species has a distinctive morphology. Conical lorica, with a long caudal spine. Occipital margin with four or six asymmetrical spines of diverse length. Edmondson \& Litt (1989) observed differences between biometry of populations from lakes of different temperature and latitudes.

Geographical distribution. Found frequently and in relatively abundance in lakes from the
Centre of Europe and also in lakes of the Pyrenean mountains. It was recorded for the first time in the Lake Banyoles in 1977 (Miracle \& Vicente, 1983), probably a migrant from northern latitudes.

Distribution in reservoirs. For the first time it has been found in reservoirs, though in scarce numbers. Only collected in summer samples from two reservoirs in the NE of the Iberian Peninsula: Boadella (79) and Sta. Anna (93). Probably resting eggs of $K$. longispina reached these reservoirs from Pyrenean lakes, which are relatively close.

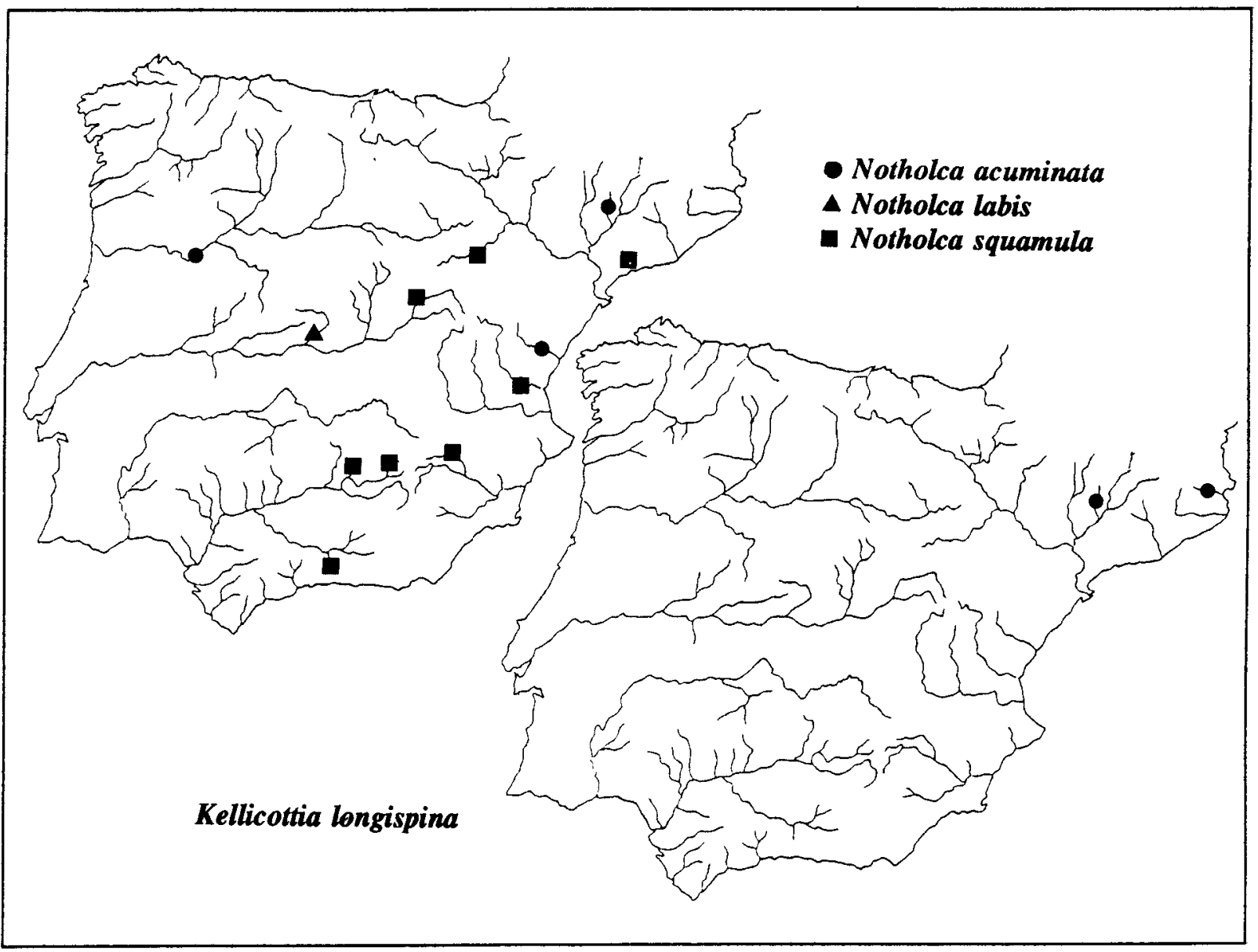

Figure 10. Distribution of some species of the genus Notholca and of Kellicottia longispina in Spanish reservoirs. Distribucion de algunas especies del género Notholca y de Kellicottia longispina en los embalses españoles. 


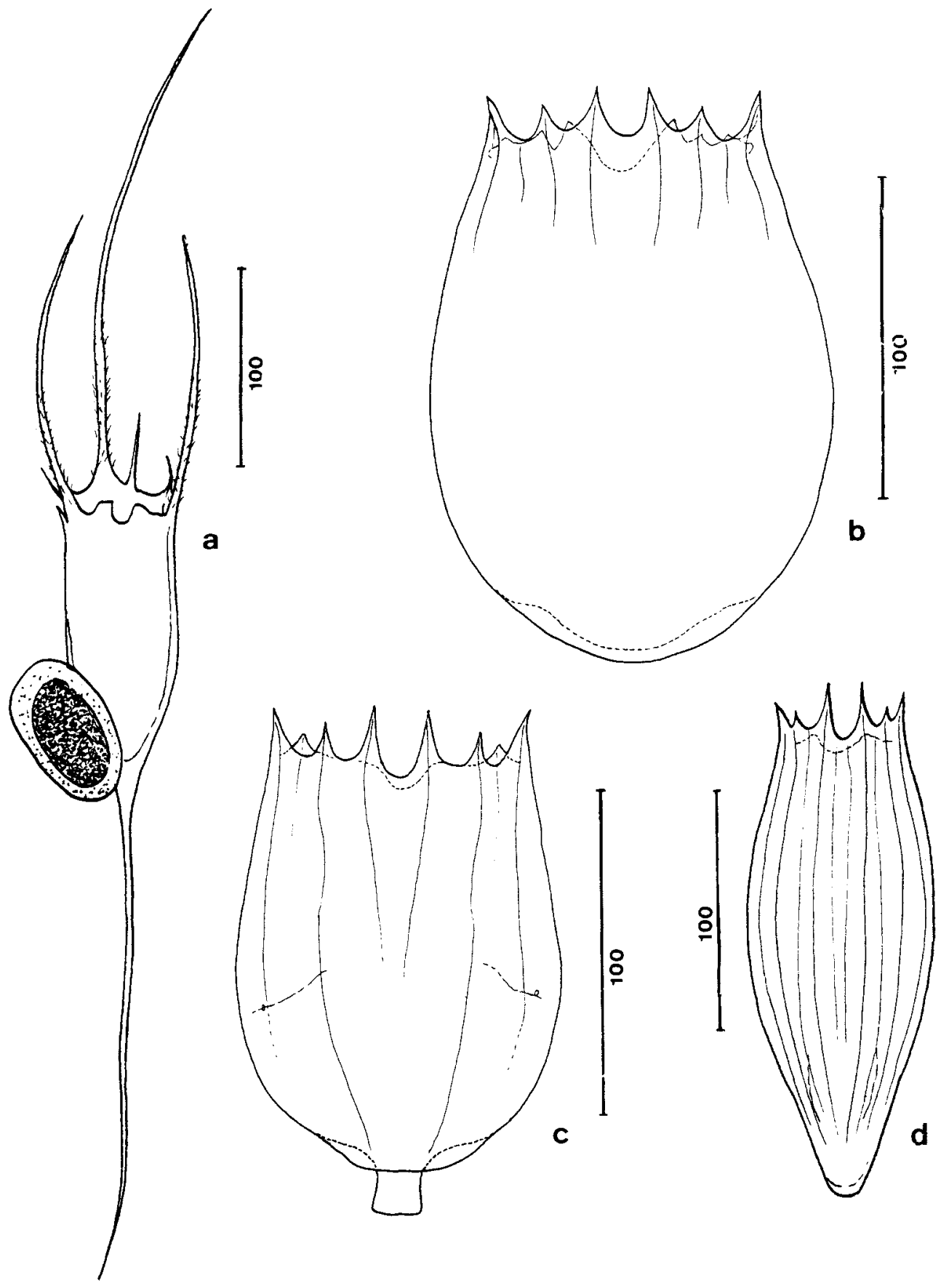

Figure 11. Kellicottia longispina and species of Notholca collected in Spanish reservoirs during the 87/88 survey. Scale in $\mu \mathrm{m}$. a. Kellicottia longispina from Boadella; b. Notholca squamula from Bermejales; c. N. Labis from Cazalegas; d Notholca acuminata from St. Anna. Kellicottia longispina y especies de Notholca identificadas en los embalses españoles (estudio 87/88). Escala en $\mu m$. a. Kellicottia longispina de Boadella; $b$. Notholca squamula de Bermejales; $c$. N. labis de Cazalegas; $d$ Notholca acuminata de St. Anna. 
Genus Notholca Gosse

Notholca acuminata (Ehrenberg, 1832) (Fig. 11

d) (Fig. 10)

Anuraea acuminata Ehrenberg, 1832.

Ecology. Heleoplanktonic species. Cold stenoterm. More frequent in littoral benthos than in plankton, where it is found occasionally. It feeds on central and pennal diatoms (Pourriot, 1977).

Cond: 293-821 $\mu \mathrm{S} \mathrm{cm}^{-1}$; Alk: 1996-3039.3 peq $\mathrm{I}^{-1}$; pH: 7.69-8.2; Temp: $10.63-11.57^{\circ} \mathrm{C}$

Morphological features of interest. Lorica longitudinally striated, with six spines on the anterior margin. It presents a caudal appendix of variable length.

Geographical distribution. It has been found in Europe, North of Africa and Asia Minor. Common in the Iberian Peninsula.

Distribution in reservoirs. In the previous study it was collected in eight plankton samples. In this survey it was also found in St. Anna (93) and in Sitjar (59), in winter samples.

Notholca labis Gosse, 1887 (Fig. 11 c) (Fig. 10)

Ecology. Heleoplanktonic species. Cold stenoterm, it may be inhabit considerably saline water.

Cond: $112 \mu \mathrm{S} \mathrm{cm}^{-1}$; Alk: 779 peq l-1; $\mathrm{pH}: 7.53$; Temp: $9.5^{\circ} \mathrm{C}$

Morphological features of interest. Lorica elongated and oval, striated longitudinally, with almost rectangular and spade-shaped caudal extensions. Gosse compared its lorica with the handle of a dust pan (Fig. 11 c). Polymorphic.

Geographical distribution. Probably cosmopolite. Rare. In Spain it has only been found in reservoirs and in Pyrenean lakes (unpublished data).

Distribution in reservoirs. It was found in the previous study in Sobron (91). In the 1987/88 study it has been found in a reservoir of the basin of the river Tajo, Cazalegas (52) (Fig. 10), in samples taken during the mixing period.

Notholca squamula (Muller, 1786) (Fig. 11 b) (Fig. 10)

Brachionus squamula Muller, 1786.
Ecology. Planktonic species, but frequently found in littoral environments. It tolerates a wide range of salinity. Cold stenoterm. It feeds mainly on diatoms.

Cond: $189-1126.3 \mu \mathrm{S} \mathrm{cm}^{-1}$; Alk: $689.5-4681.7$ peq $\mathrm{l}^{-1}$; $\mathrm{pH}$ : 7.9-8.5; Temp: $8.4-12.3^{\circ} \mathrm{C}$

Morphologicalfeatures of interest. Lorica with rounded caudal margin, finely striated, with six spines on the anterior dorsal margin. The quotient length/width is always less than 2. It presents cyclomorphosis and it is frequently larger at low temperature.

Geographical distribution. It is the most common species of the genus and it is widespread throughout the Iberian Peninsula. In littoral ponds it may be easily confused with $N$. salina (Focke)

Distribution in reservoirs. It was found mainly in eutrophic reservoirs with alkaline waters. It has been collected in winter samples from eight localities of eastern areas of the Iberian Peninsula (Fig. 10).

\section{Genus Platyias (Harring)}

Platyias quadricornis (Ehrenberg, 1832)

Noteus quadricornis Ehrenberg, 1832; Platyias quadricornis (Ehrenberg) after Harring, 1913.

Ecology. Heleoplanktonic species. Prefers warm water and presents tolerance to moderate salinity. It is frequently found among littoral macrophytes (Pejler, 1977).

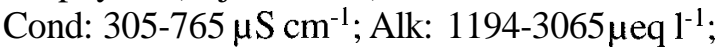
pH: 8-8.5; Temp: $21.82-22.8^{\circ} \mathrm{C}$

Morphologicalfeatures of interest. Lorica with a pentagonal dorsal facet between two hexagonal facets. The species presents variability in the size and length of its caudal spines. Eggs are carried, like other brachionidae, on the opening of the foot.

Geographical distribution. Cosmopolite, more common in tropical and subtropical regions. In Spain it has occasionally been found, mainly coastal ponds: Doñana National Park (De Ridder, 1962); Cullera (Miracle \& Vicente, 1983); and in rice fields of the delta of river Ebre (Forés et al. 1986). 
Distribution in reservoirs. Rare. In the present study it has been found in plankton samples from Boadella (79) and Flix (35).

\section{Family EUCHLANIDAE}

Genus Euchlanis Ehrenberg

\section{Euchlanis dilatata Ehrenberg, 1832}

Ecology. Heleoplanktonic species. Frequent among macrophytes in small waterbodies. Tolerates moderate concentrations of salinity and may occur in fresh and brackish water. It prefers eutrophic water, especially when cyanobacteria are abundant. Pejler (1962) remarks it is a species that frequently appears attached to planktonic algae colonies. According to Carlin (1943), it feeds on organic detritus, bacteria, cyanophicea and Cyclotella.

Cond: $19.6-823 \mu \mathrm{S} \mathrm{cm}^{-1}$; Alk: $98-3757 \mu \mathrm{eq}{ }^{-1}$; pH: 6.3-9.6; Temp: $6.4-24{ }^{\circ} \mathrm{C}$

Morphological features of interest. Ovoid body, lorica transparent and flexible. Lorica is truncate at its anterior margin and was a rounded posterior end. Posterior dorsal plate is divided by a deep elongate notch. Foot slender and twojointed. Size is remarkably variable and several specific morphs have been described attending to the section and shape of the lorica.

Geographical distribution. Cosmopolite. It has been found all over Spain.

Distribution in reservoirs. In the 1987188 survey it was identified in samples, from 19 reservoirs across the whole Iberian Peninsula, both from the stratificatin period and after mixing. In the previous study its occurrence was important in spring.

\section{Family MYTILINIDAE}

Genus Lophocharis Ehrenberg

Lophocharis salpina (Ehrenberg, 1834) (Fig. 12 c; Fig. 13)

Lepadella salpina Ehrenberg, 1834; Metopidia salpina Hudson \& Gosse, 1889; Lophocharis salpina after Harring, 1916.

Ecology. Periphytic species, occasionally occurring in plankton. It inhabits preferentially alkaline waterbodies. It also may be found in dystrophic environments.

Cond: $77-3130 \mu \mathrm{S} \mathrm{cm}^{-1}$; Alk: $429.2-3038 \mu \mathrm{eq}{ }^{1-1}$; pH: 7.1-8.1; Temp: 8.6-24. $3^{\circ} \mathrm{C}$

Morphological features of interest. Robust lorica, of triangular section, with the anterior margin always serrated. It presents a dorsal keel with transverse folds mostly over caudal part of the lorica. Trophi malleate, with six teeth on uncus. Foot ventrally curved, with three joints and toes sharply pointed. I may be confused with L. oxysternon (Gosse, 1851), which does not present caudal folds on the dorsal keel.

Geographical distribution. Cosmopolite. It is an uncommon species, but has been found spread across the whole Iberian Peninsula territory (unpublished data), in spite of the fact that it has been recorded in few localities (Velasco, 1990).

Distribution in reservoirs. In the 1987188 survey it was found in seven localities (Fig. 4.12), mainly in winter samples (mixing period).

\section{Family TRICHOTRIIDAE}

\section{Genus Trichotria Bory de St. Vincent}

Trichotria pocillum (Miiller, 1776) (Fig. 12 e)

Trichoda pocillum Miiller, 1776; Dinocharis pocillum Ehrenberg, 1830; Trichotria pocillum, Bory de St. Vincent, 1827.

Ecology. Periphytic species, heleoplanktonic. It feeds on organic detritus and algae, mainly diatoms from phytobenthos. It tolerates a wide range of mineralization.

Cond: 262-378.5 $\mu \mathrm{S} \mathrm{cm} \mathrm{cm}^{-1}$; Alk: 2103-2987 $\mu$ eq $\mathrm{I}^{-1}$; $\mathrm{pH}: 7.5-8.1$; Temp: $7.7-9.1^{\circ} \mathrm{C}$

Morphological ,features of interest. Robust lorica covering head, body and feet, like a shield of hexagonal section. Lorica ornamented with spicules and organized in regular facets (with similarities with the lorica of some brachionids). Trophi malleate. Foot with two long and slender toes. T. pocillum has a small spine in the last segment of the foot, just between the two toes (Fig. 12 e). This trait makes it possible to distinguish this species from $T$. tetractis (Ehrenberg, 1830). 


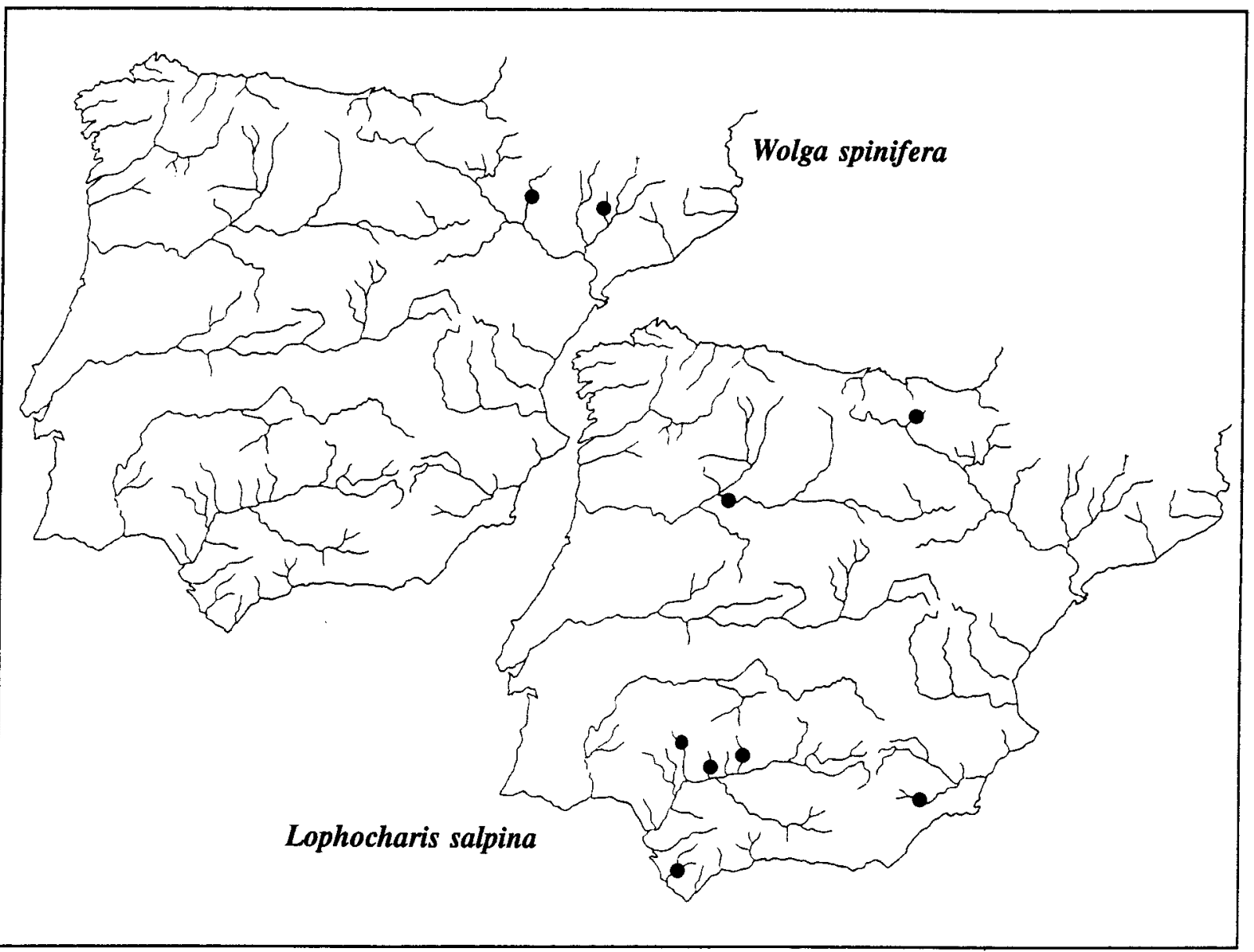

Figure 13. Distribution of Lophocharis salpina and Wolga spinifera in Spanish reservoirs (survey 87/88). Distribución de Lophocharis salpina $y$ Wolga spinifera en los embalses españoles (estudio 87/88).

Geographical distribution. Cosmopolite. In Spain it is widespread.

Distribution in reservoirs. It has only been found only in winter samples, from Villalcampo (26) and Sobrón (91). In the previous survey it was collected in nine reservoirs.

Trichotria tetractis (Ehrenberg, 1830) (Fig. 12 d) Dinocharis tetractis Ehrenberg, 1830; Trichotria tetractis after Carlin, 1939.

Ecology. Ecological affinity with T. pocillum.

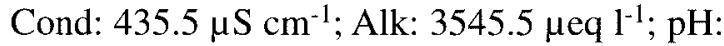

8.1; Temp: $18.8^{\circ} \mathrm{C}$
Morphological features of interest. Lorica features are remarkably variable. Ornamentation and size may be very different. The absence of a short spine between toes on the last foot segment distinguishes it from T. Pocillum in the same genus.

Geographical distribution. Cosmopolite. In Spain less frequent than T. pocillum.

Distribution in reservoirs. It has been found in summer samples from Sobrón (91). In the previous study it was collected in five reservoirs. 

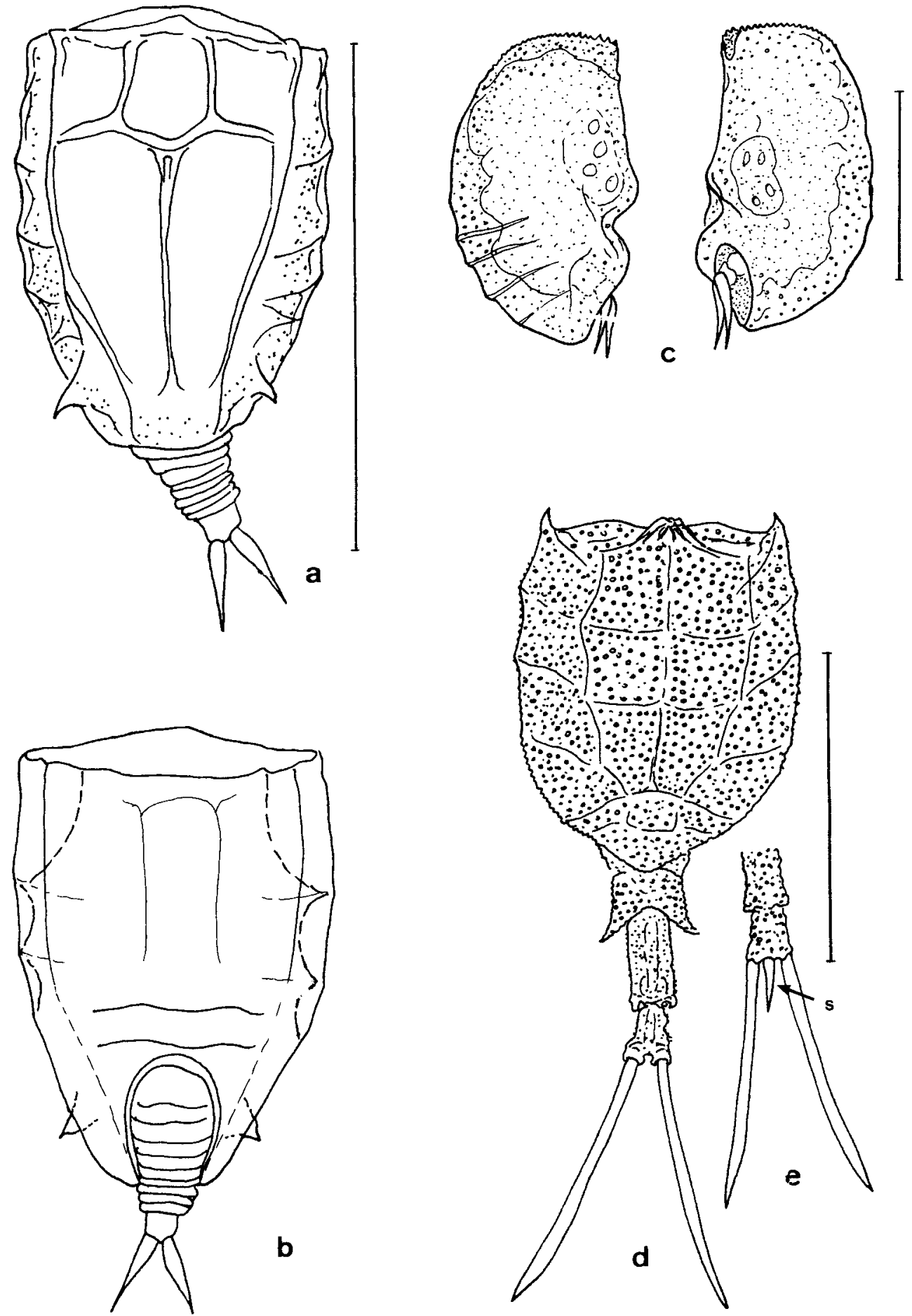

Figure 12. Rotifers of the families Mytilinidae and Trichotriidae found in Spanish reservoirs during the $87 / 88$ survey. Scale bar is $100 \mu \mathrm{m}$ long. Rotiferos de las familias Mytilinidae y Trichotriidae identificados en los embalses españoles (estudio 87/88). Escala 100 um. 
Genus Wolga Skorikov

Wolga spinifera (Western, 1894) (Fig. 12 a,b) (Fig. 13)

Distyla spinifera Western, 1894; Cathypna spinifera Murray, 1913; Lecane spinifera, Harring, 1913; Wolga spinifera after Skorikov, 1903.

Ecology. Heleoplanktonic species. Its ecology is not well known. Its presence in some Eastern reservoirs of the Iberian Peninsula (Fig. 4.12) suggest its preference for alkaline environments.

Cond: 351-359 $\mu \mathrm{S} \mathrm{cm} \mathrm{cm}^{-1}$; Alk: 2014.8-2731 eq $^{1-1}$; pH: 8.3-8.4; Temp: $18-20.4{ }^{\circ} \mathrm{C}$

Morphological features of interest. Lorica compressed, dorsally divided by two ribs that define a series of facets. Oval foot opening under a distinct transverse fold of the ventral plate. Toes short, slender, pointed. It presents two lateral dorsal spines at the level of the lateral antennae.

Geographical distribution. Probably cosmopolite. Rare, frequently found in Europe and Àsia Minor (Berzins, 1978). In the Iberian Peninsula it has only been found in reservoirs.
Distribution in reservoirs. Recorded for the first time in Spain in the 1972/75 survey. According to Guiset (1977a), this species has possibly been introduced from higher latitudes and can now be found in more southern localities. In the recent study it has been found in St. Anna (93) and La Sotonera (1), both in the basin of the river Ebre.

\section{Family COLURELLIDAE}

Genus Colurella Bory de St. Vincent

Colurella adriatica Ehrenberg, 1831 (Fig. 14 a,b)

Colurella lepta Diefenbach, 1912.

Ecology. Heleoplanktonic species. Eurihaline, occurring also in current water (in the littoral zone, among macrophytes).

Cond: $383.7 \mu \mathrm{S} \mathrm{cm}^{-1}$; Alk: $3349.7 \mu \mathrm{eq} 1^{-1}$; $\mathrm{pH}$ : 8.4; Temp: $23.5^{\circ} \mathrm{C}$

Morphological features of interest. Lorica very variable in size and shape. It is characterized by the divergence of the posterior margin, which has a pointed and acute shape (Fig. 14). Pejler (1962) found a transition morph between $C$. adriatica
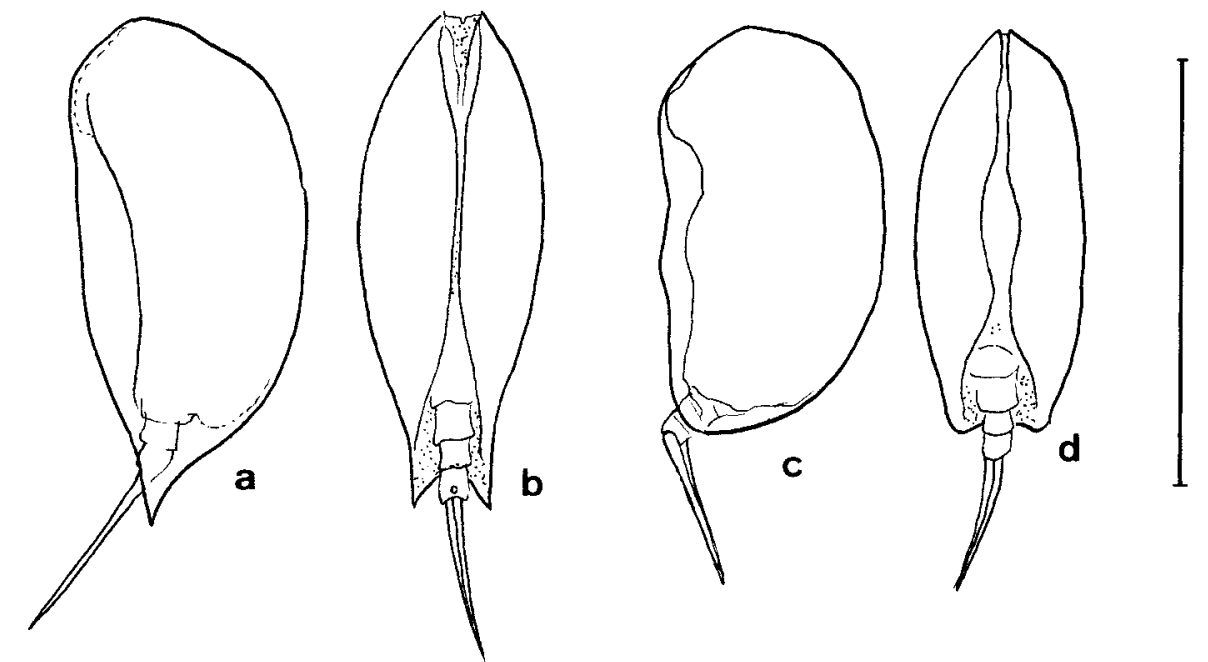

Figura 14. Some species of the genus Colurella found in Spanish reservoirs (survey 87/88). Scale $100 \mu \mathrm{m}$. a, b, C. adriatica lateral and ventral, from Cenajo; c, d, C. colurus, lateral and ventral, from Frieira. Algunas especies del género Colurella identificadas en los embalses españoles (estudio 87/88). Escala $100 \mu m$. a, b, C. adriatica lateral y ventral, de Cenajo; $c, d$, C. colurus, lateral $i$ ventral, de Frieira. 

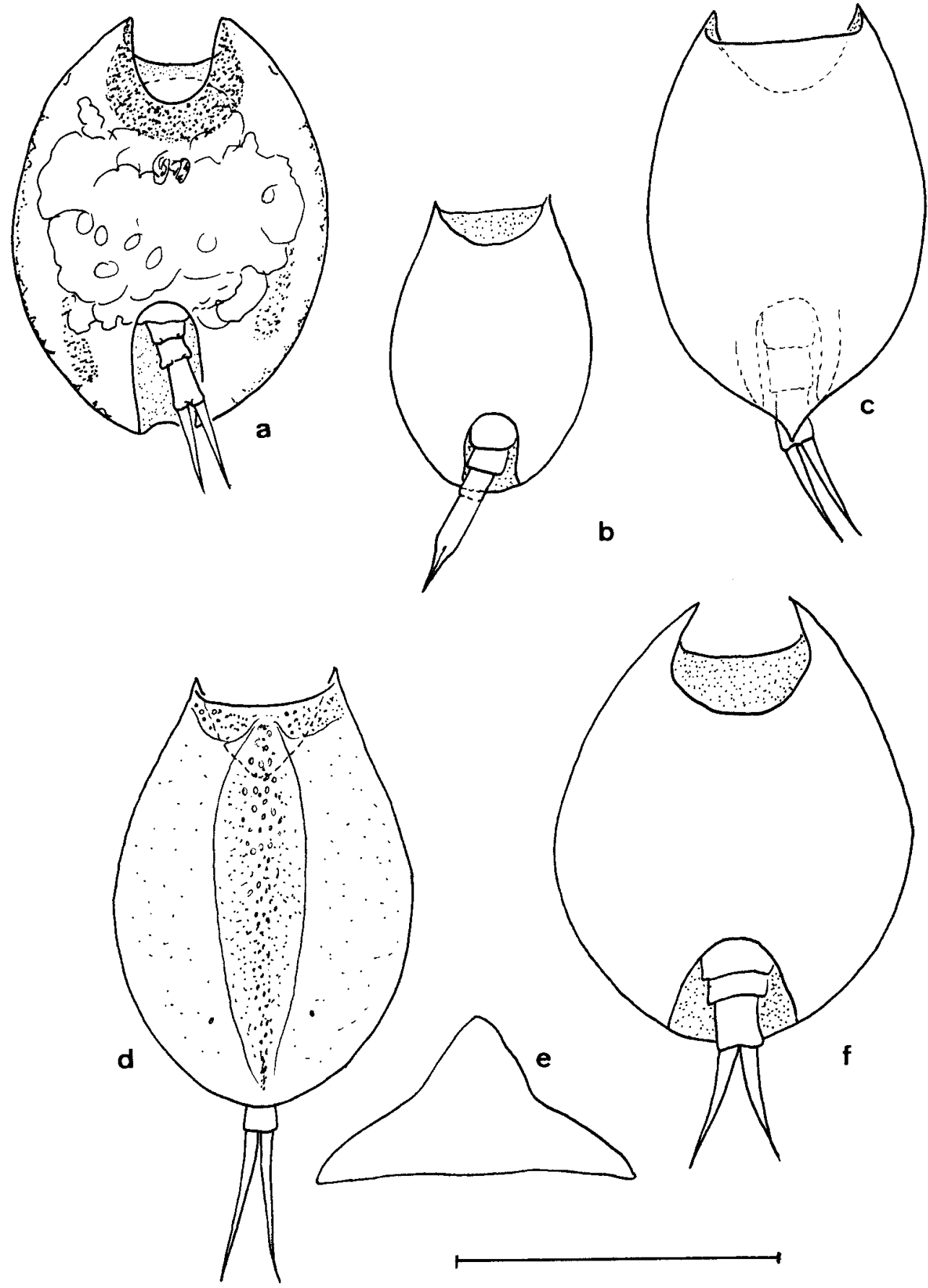

Figure 15. Species of the genus Lepadella found in Spanish reservoirs (survey 87/88). Scale $100 \mu \mathrm{m}$. a. L. patella, ventral, from Das Conxas; b. L. acuminata, dorsal, from Aguilar de Campoo; c, $L$. (X.) astacicola, ventral, El Vellón; d,e, L. rhomboides, d, dorsal, e, cross section, Guadalén; e, L. ovalis, ventral, from San Juan. Especies del género Lepadella identificados en los embalses españoles (estudio 87/88). Escala 100 um. a. L. patella, ventral, Das Conxas; $b$, L. acuminata, dorsal, de Aguilar de Campoo; $c$, L. (X.) astacicola, ventral, El Vellón; d,e, L. rhomboides, $d$, dorsal, e, sección transversal, Guadalén; e, L. ovalis, ventral, de San Juan. 
and C. colurus. Different ecotypes have been described in relation to the size and shape of the lorica, as well as length of the foot. Both species increased their size with salinity (Hauer, 1924).

Geographical distribution. Probably cosmopolite. In Spain it has been found in numerous and widespread localities.

Distribution in reservoirs. It has been collected only in Cenajo (75), in summer samples. In the previous survey it was found in five reservoirs.

Colurella colurus Ehrenberg, 1830(Fig. 14c,d)

Monura colurus Ehrenberg, 1830; Colurella colurus after Harring, 1913.

Ecology. Heleoplanktonic species. Eurihaline. With similar ecological requirements C. adriatica.

Cond: $77 \mu \mathrm{S} \mathrm{cm}^{-1}$; Alk: 429.2 peq $\mathrm{l}^{-1}$; $\mathrm{pH}$ : 7.1; Temp: $9.7^{\circ} \mathrm{C}$

Morphological features of interest. Relatively smaller than C. adriatica, it may be discriminated by the morphology of the posterior margin of the lorica, which is rounded in C. colurus (Fig. 14).

Geographical distribution. Cosmopolite. In the Iberian peninsula it has been found in fewer localities than expected from its know distribution (unpublished data).

Distribution in reservoirs. In the previous study it was found in seven reservoirs. In the last survey it was only found in Frieira (97) and only in winter.

\section{Colurella uncinata (Muller, 1773)}

Brachionus uncinatus Muller, 1773; Colurella uncinata after Harring, 1913.

Ecology. Periphytic species, occasional in plankton. It tolerates a wide range of mineralization.

Cond: $383.7 \mu \mathrm{S} \mathrm{cm}^{-1}$; Alk: $3349.7 \mu \mathrm{eq} \mathrm{l}^{-1}$; $\mathrm{pH}$ : 8.4; Temp: $23.5^{\circ} \mathrm{C}$

Morphologicalfeatures of interest. Lorica with a head-opening smaller than the greatest lorica height. Lorica ends in its posterior end with a downward-curving short spine. Short toes.

Geographical distribution. Cosmopolite. In the Iberian Peninsula it is more common in Eastern regions (Velasco, 1990).

Distribution in reservoirs. It has been identi- fied in Cenajo (75). In the previous survey it was collected in five reservoirs.

Genus Lepadella Bory de St. Vincent

The genus has been traditionally split into three subgenera distingued by the morphology of the toes: Lepadella (equal toes; completely separate); Heterolepadella (unequal toes); Xenolepadella (joined toes; either totaly or parcially).

Lepadella acuminata (Ehrenberg, 1834) (Fig. 15 c; Fig. 16)

Metopidia acuminata Ehrenberg, 1834; Lepadella acuminata after Dujardin, 1841.

Ecology. Periphytic species, occasionally found in plankton. According to Koste (1978) it prefers slightly acid water.

Cond: 51.5-304.7 $\mu \mathrm{S} \mathrm{cm}{ }^{-1}$; Alk: 171-2089 $\mu$ eq $\mathrm{l}^{-1}$; pH: $6.8-8.3$; Temp: $7.8-19{ }^{\circ} \mathrm{C}$

Morphological features of interest. Dorsal lorica with two lateral keels. Lorica ends with an acute margin. This character distinguishes this species from the other species in the genus.

Geographical distribution. Cosmopolite. In the Iberian Peninsula it has been found quite a few localities, all with low mineralization. It one of the most common species of this genus in high mountain lakes; for instance in Sierra Nevada (Morales-Baquero, 1987), as well as in Pyrenean mountains (Margalef, 1948b, and unpublished data).

Distribution in reservoirs. It has been found in three northern localities, Aguilar de Campoo (7), As Conxas (20) and Barasona (92), in all of them in summer samples. In the previous survey it was collected in five localities.

Lepadella (Xenolepadella) astacícola Hauer, 1926 (Fig. 15b; Fig. 16)

Ecology. Littoral species. It has been described as inhabitant of the bronchial cavity of the river crayfish (of the genus Astacus and Cwitharus).

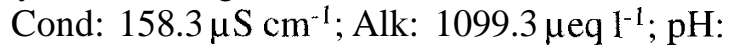
9.19; Temp: $17.7^{\circ} \mathrm{C}$.

Morphological features of interest. Its most distinctive character is the complete fusion of the toe. 


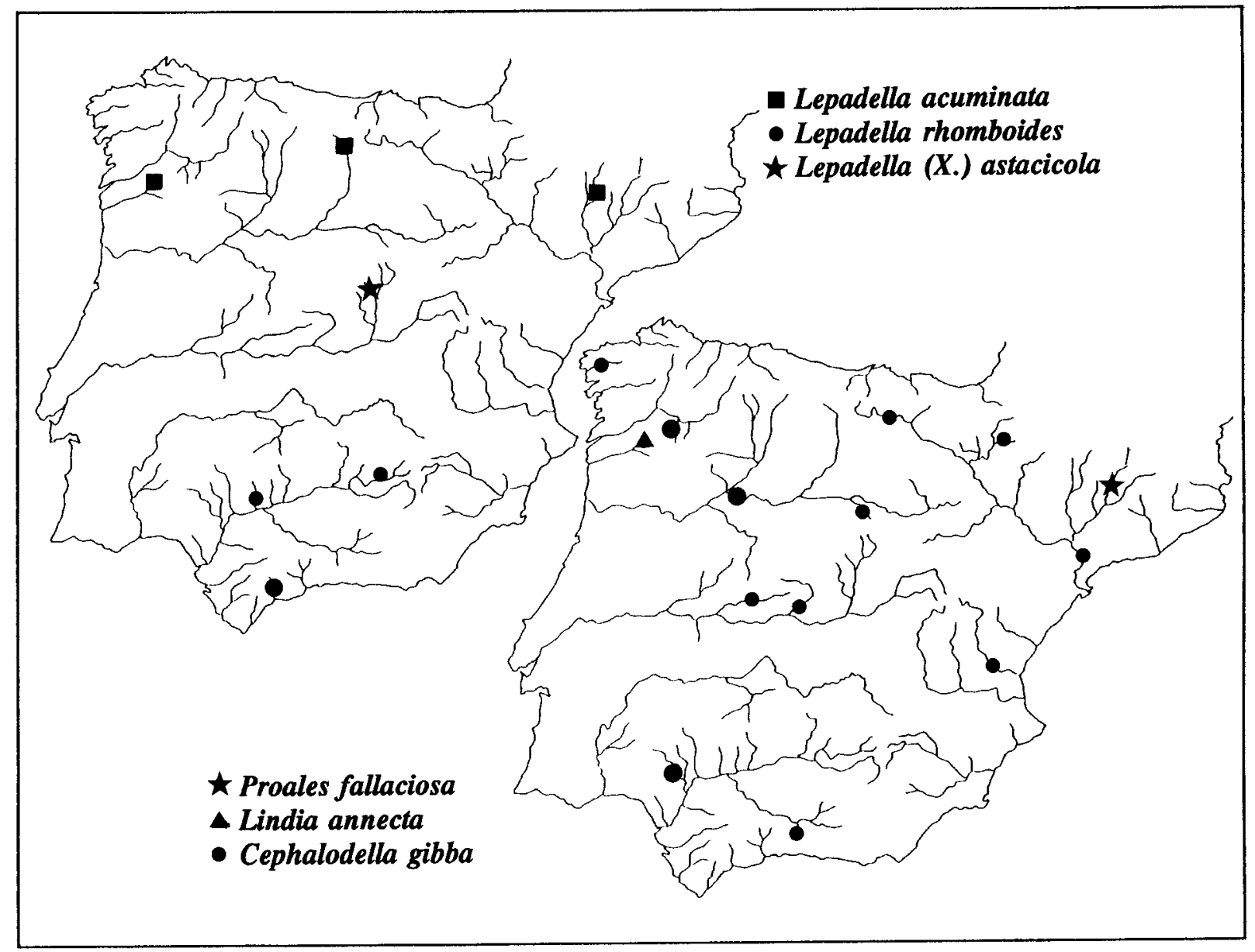

Figure 16. Distribution of some species of genera Lepadella, Lindia and Cephalodella in Spanish reservoirs during the 87/88 survey. Distribución de algunas especies de los géneros Lepadelia, Lindia y Cephalodella en los embalses españoles (estudio 87/88).

Geographical distribution. Probably, its distribution is determined by the presence of crayfish. Results reported here are the first record of the species presence in the Iberian Peninsula.

Distribution in reservoirs. Interestingly, it has been found in plankton samples from El Vellón (60). Its presence in the plankton suggests that the species does not live exclusively in the brachial cavity of the crayfish, but occasionally have a heleoplanktonic habitat, or even live in different habitats during its life cycle.

Lepadella ovalis (Müller, 1786) (Fig. 15 f)

Brachionus ovalis, Müller, 1786; Lepadella ovalis after Ehrenberg, 1830; Metopidia solidus,
Gosse, 1851; Metopidia ovalis Anderson \& Shepard, 1892.

Ecology. Heleoplanktonic, common in littoral zones, among macrophytes. Eurihaline, but more frequent in fresh water.

Cond: $48-498 \mu \mathrm{S} \mathrm{cm}^{-1}$; Alk: 266-2468 $\mu \mathrm{eq} \mathrm{l}^{-1}$; $\mathrm{pH}$ : 8.58-9.14; Temp: $23.6-24{ }^{\circ} \mathrm{C}$.

Morphological features of interest. Body depressed. Ventral lorica nearly flat, outline oval to circular. Head-opening with a ventral sinus of rhomboidal shape. Foot-opening variable. Resting eggs covered by, slightly curved robust spines

Geographical distribution. Cosmopolite. Present throughout the Iberian Peninsula. 
Distribution in reservoirs. It has been collected in San Juan (41) and San Román (98). In the previous survey it was only found in one reservoir.

Lepadella patella (Muller, 1786) (Fig. 15 a)

Brachionus patella Müller, 1786; Lepadella patella after Bory de St. Vincent, 1826.

Ecology. Littoral species, periphytic, found occasionally in plankton from reservoirs, rivers and ponds. Uncommon in large waterbodies.

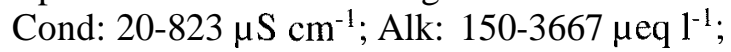
pH: 6.7-9.3; Temp: $9.1-22.3{ }^{\circ} \mathrm{C}$.

Morphological features of interest. Outline of the lorica variable, elliptical, with a food opening also variable U-or-V shaped. Ventral sinus with a wider frontal part. Foot-opening with two small pointed margins.

Geographical distribution. Cosmopolite. It is the most common species of the genus in the Iberian Peninsula.

Distribution in reservoirs. It has been found in 11 reservoirs spread across the Iberian Peninsula.

Lepadella rhomboides (Gosse, 1886) (Fig. 15 d,e; Fig. 16)

Metopidia rhomboides Gosse, 1886; Lepadella rhomboides after Harring, 1913.

Ecology. Periphytic species, heleoplanktonic. It tolerates a wide range of $\mathrm{pH}$ (Berzins \& Pejler, 1987; Koste \& Shiel, 1989b), but prefes alkaline water.

Cond: 250.3-433 $\mu \mathrm{S} \mathrm{cm}^{-1}$; Alk: 2047.3-2519 $\mu$ eq $\mathrm{l}^{-1}$; pH: 8.26-9; Temp: $24.9-26.7^{\circ} \mathrm{C}$.

Morphologicalfeatures of interest. Lorica with a moderately high arched median keel. Dorsal sinus U- shaped, and ventral sinus V-shaped. Dorsal aperture of the head opening presents a collar which can be bordered by a thick granulated cuticule. Foot-opening U-shaped, with parallel sides. Long distal foot-segment. Toes relatively shorter and slightly curved.

Geographical distribution. Cosmopolite. In Spain it has only been collected in Alacant (Rojo \& Oltra, 1986), on the Central Mediterranean coast, and in the Balearic archipelago (De Manuel et al., 1992) because of this we expect a widespread distribution of this species.
Distribution in reservoirs. Found in summer samples from Guadalén (62), Retortillo (69) and La Concepción (102).

Family LECANIDAE

Genus Lecane Nitzsch

Several authors distinguish the genus Monostyla (with only one toe) from Lecane (with two toes). Both genus were initially included in the family Euchlanidue. Edmondson (1935) proposed unification, including both in the same genus Lecane. Later, Bartos (1959) sustained that Monostyla and Lecane belonged to the family Lecanidae, adding also the subgenus Hemimonostyla (intermediate forms where the fusion of the toes has only been partial). Koste (1978) gave to Hemimonostyla and Monostyla the taxonomic category of subgenus, later Koste \& Shiel (1990a) separated Lecane and Monostyla as two different genera, and gives taxonomic category of genus to Hemimonostyla. More recently, Segers (1993) questioned the separation of the genus based only on the criteria of the fusion of the toes, and proposed synonymy between Lecane, Monostyla and Hemimonostyla.

Lecane (M.) bulla Gosse, 1851 (Fig. 18 a; Fig. 19)

Monostyla bulla Gosse, 1851.

Ecology. Periphytic species, occasionally found in plankton samples. Very common among macrophytes in small waterbodies. The species prefers high concentrations of carbonates.

Cond: 56.7-3590 $\mu \mathrm{S} \mathrm{cm}^{-1}$; Alk: 51.5-498 peq $\mathrm{l}^{-1}$; pH: $6.8-8.2$; Temp: $10-19.35^{\circ} \mathrm{C}$

Morphologicalfeatures of interest. It is characterized by a $\mathrm{V}$-shaped dorsal opening of the lorica, and a small U-shaped notch on the posterior margin (where the dorsal antenna protrudes). It presents a long toe, ended by a claw with basal spicules and a undivided claw with a medial line undivided.

Geographical distribution. Cosmopolite. Common in the Iberian Peninsula and the Balearic Islands.

Distribution in reservoirs. Its distribution in Spanish reservoirs is preferentially in eastern 

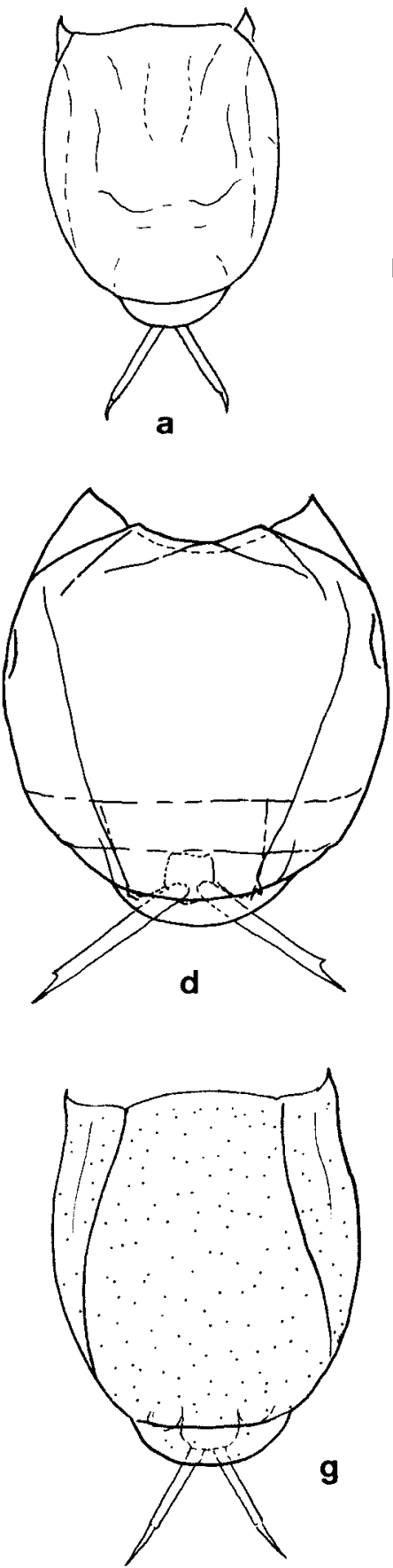

g
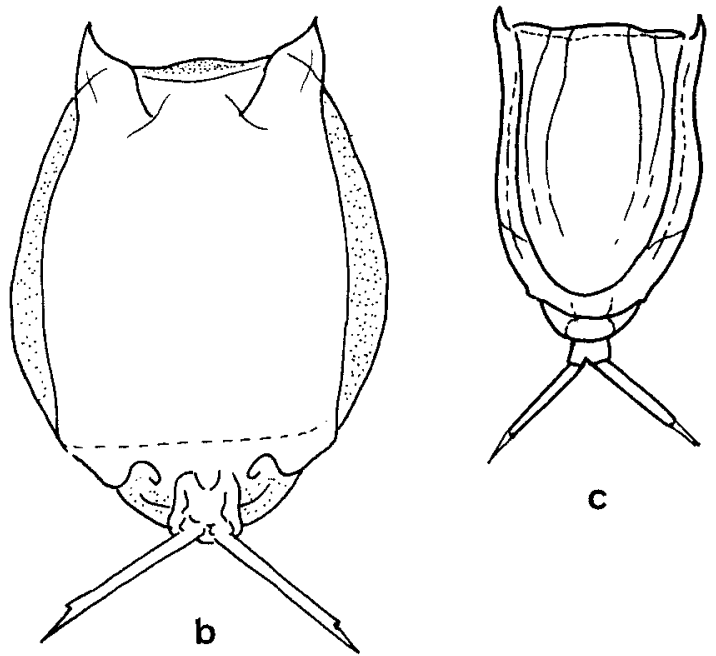

c
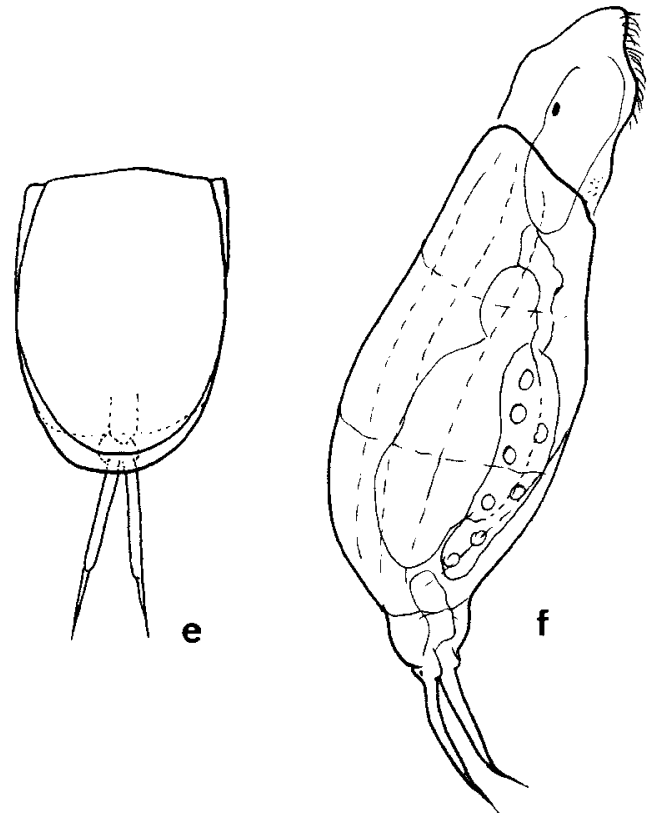

Figure 17. Some species of the genus Lecane found in Spanish reservoirs (survey 87/88). Scale $100 \mu \mathrm{m}$. a. Lecane flexilis, dorsal, from Arbón; b. L. mira, ventral, from Salime; c. L. crepida, dorsal, from La Concepción; d. L. luna, dorsal, from La Concepción; e. L. tenuiseta, dorsal, from Boadella; f. L. inermis, lateral, from Chandrexa; g. L. hastata, dorsal, from Villalcampo.

Algunas especies del género Lecane identificadas en los embalses españoles (estudio 87/88). Escala 100 $\mu m$. a. Lecane flexilis, dorsal, de Arbón; b. L. mira, ventral, de Salime; c. L. crepida, dorsal, de La Concepción; d. L. luna, dorsal, de La Concepción; e. L. tenuiseta, dorsal, de Boadella; f. L. inermis, lateral, de Chandrexa; g. L. hastata, dorsal, de Villalcampo. 
regions, in reservoirs located in calcareous basins.

Lecane (M.) closterocerca (Schmarda, 1859) (Fig. $18 \mathrm{c}$ )

Monostyla closterocerca Schmarda, 1859.

Ecology. Littoral species, frequently found in plankton samples. Tolerates a wide range of salinity.

Cond: $51.5-498 \mu \mathrm{S} \mathrm{cm}{ }^{-1}$; Alk: 171-3657.7 $\mu$ eq $\mathrm{l}^{-1}$; $\mathrm{pH}$ : 6.7-9.1; Temp: 7.8-24 "C

Morphologicalfeatures of interest. Head aperture dorsal and ventral margins similar, V-shaped sinuses with widely-flaring convex sides; transverse ventral fold in front of foot. One long toe, minor than $1 / 3$ body length and without claw:

Geographical distribution. Cosmopolite. It has been found accassionally in Spain (Velasco, 1990), but it is probably a very common species, widespread in the Iberian peninsula and Balearic archpelago.

Distribution in reservoirs. It has been found in six localities.

Lecane (M.) copeis Harring \& Myers, 1926 (Fig. 18 d; Fig. 19)

Monostyla copeis Harring \& Myers, 1926.

Ecology. Littoral species.

Cond: $351 \mu \mathrm{S} \mathrm{cm}^{-1}$; Alk: 2014.8 peq $^{-1}$; $\mathrm{pH}$ : 8.37; Temp: $17.9^{\circ} \mathrm{C}$

Morphologicalfeatures of interest. Head aperture margin coincident, slightly concave; transverse ventral fold in front of foot, with a short toe (less than 1/4 of its total body length) and spindle-shaped. Foot is enlarged in its mid-section and ended by a short acute claw which allows to distinguish this species from $L$. closterocerca.

Geographical distribution. Cosmopolite. Its occurrence in reservoirs constitutes the first record of this species in the Iberian Peninsula.

Distribution in reservoirs. Specimens have been identified in plankton samples from Sta. Anna (93).

Lecane (L.)crepida (Harring, 1914) (Fig. 17 c; Fig. 19)

Ecology. Littoral species. Warm stenoterm.
Cond: $383 \mu \mathrm{S} \mathrm{cm}^{-1}$; Alk: 3882 peq $\mathrm{I}^{-1}$; $\mathrm{pH}$ : 8.8; Temp: $26.2{ }^{\circ} \mathrm{C}$

Morphological features of interest. Head aperture margin slightly convex; concave by ventral margin. External angles with acute cusps curved internally. Dorsal plate smaller than ventral plate, the latter is strongly convex and is ornamented with divergent folds. Two long toes (more than a quarter of its total body length), with slender claws.

Geographical distribution. Tropical and subtropical distribution. Rare in the Iberian peninsula; it has been recorded previously by Wiszniewski (1931), Arévalo (1932) and Miracle (1976).

Distribution in reservoirs. In the latest survey it has been found only in summer samples from the reservoir La Concepción (102).

Lecane (L.) flexilis (Gosse, 1889) (Fig. 17 a; Fig. 19)

Distyla flexilis Hudson \& Gosse, 1886; Lecane flexilis after Harring, 1913.

Ecology. Littoral species, occurring occasionally in plankton. High tolerance to alkalinity. Pejler (1962) found it more frequently in alkaline environments, and Koste (1978) records it as alkalophil. But Koste \& Shiel (1990a) found it in slightly acid water.

Cond: $22-823 \mu \mathrm{S} \mathrm{cm}^{-1}$; Alk: $131-3667$ peq $\mathrm{l}^{-1}$; pH: 6.64-7.87; Temp: 9.50-21.13 ${ }^{\circ} \mathrm{C}$

Morphological features of interest. Head aperture margin coincident and convex, with two short cusps at external angles. Dorsal plate facetted. Ventral plate narrower than dorsal. Toes long and slender, approximately a quarter of its total body length. Recurved claw with a small dorsal basal spicule.

Geographical distribution. Cosmopolite. It is a common species in littoral environments, but scarce in the Iberian Peninsula (Armengol et al., 1975; Guiset, 1976; Morales-Baquero, 1987).

Distribution in reservoirs. It has been found in six localities, four reservoirs in the NW of the Iberian Peninsula. of low mineralizated water. 

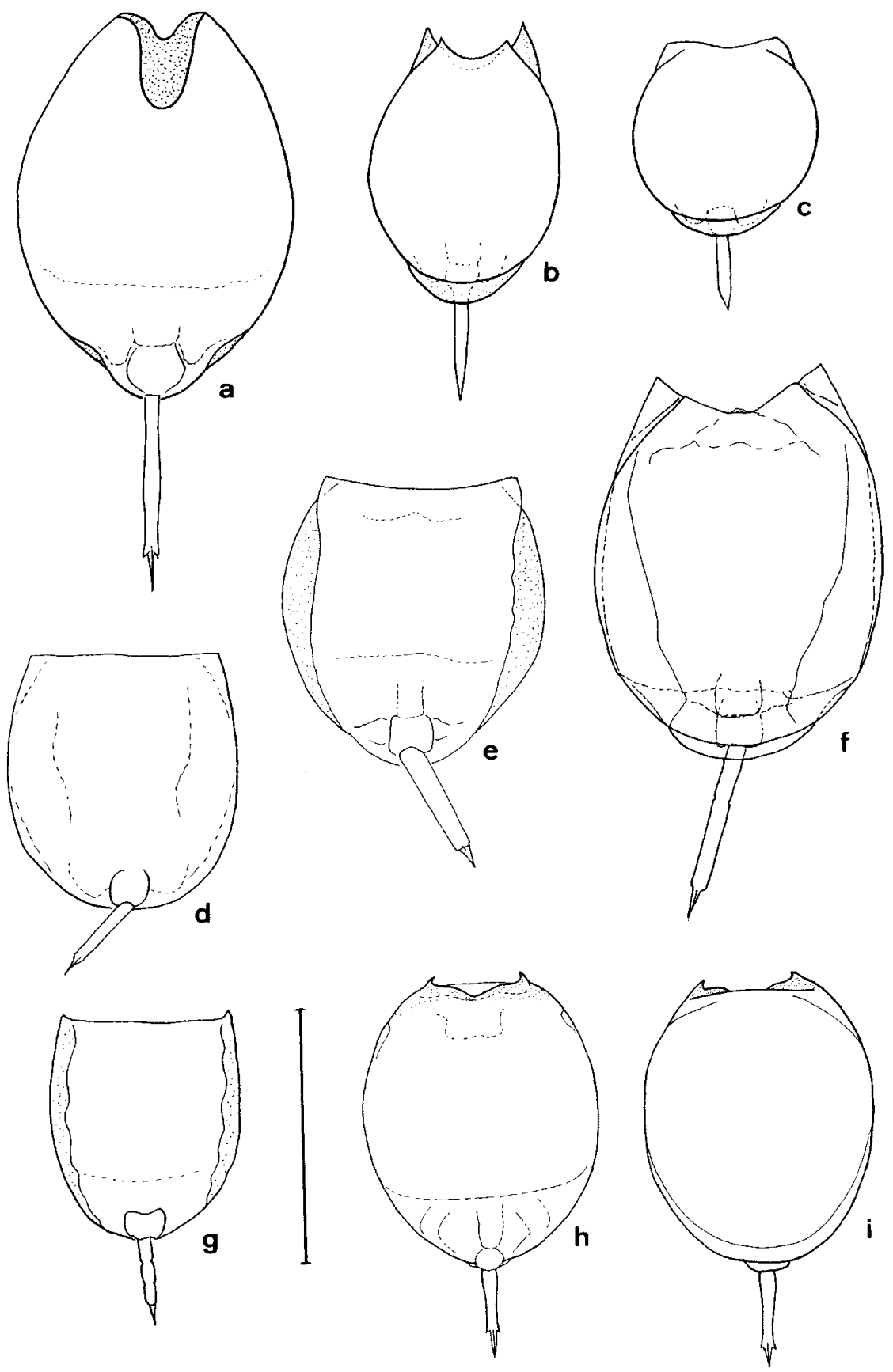

Figure 18. Some species of the genus Lecane found in Spanish reservoirs (survey 87/88). Scale bar 100 $\mu$ m. a. L. bulla, ventral, from Boadella; b. L. hamata, dorsal, from Boadella; c. L. closterocerca, dorsal, from San Román; d. L. copeis, ventral from Sta. Anna; e. L. tethis, ventral, from St. Ponç; f. L. lunaris, dorsal, from As Conchas;; g, L. scutata, ventral, from Entrepeñas; h, i, L. stenroosi, h ventral, i dorsal, from La Concepción. Algunas especies del género Lecane identificadas en los embalses españoles (estudio 87/88). Escala 100 um. a. L. bulla, ventral de Boadella; $b$. L. hamata, dorsal, de Boadella; $c$. L. closterocerca, dorsal, de San Román; d. L. copeis, ventral de Sta. Anna; e. L. tethis, ventral, de St. Ponç; f. L. lunaris, dorsal, de As Conchas; $g$, L. scutata, ventral, de Entrepeñas; $h$, $i$, L. stenroosi, $h$ ventral, $i$ dorsal, de La Concepción. 


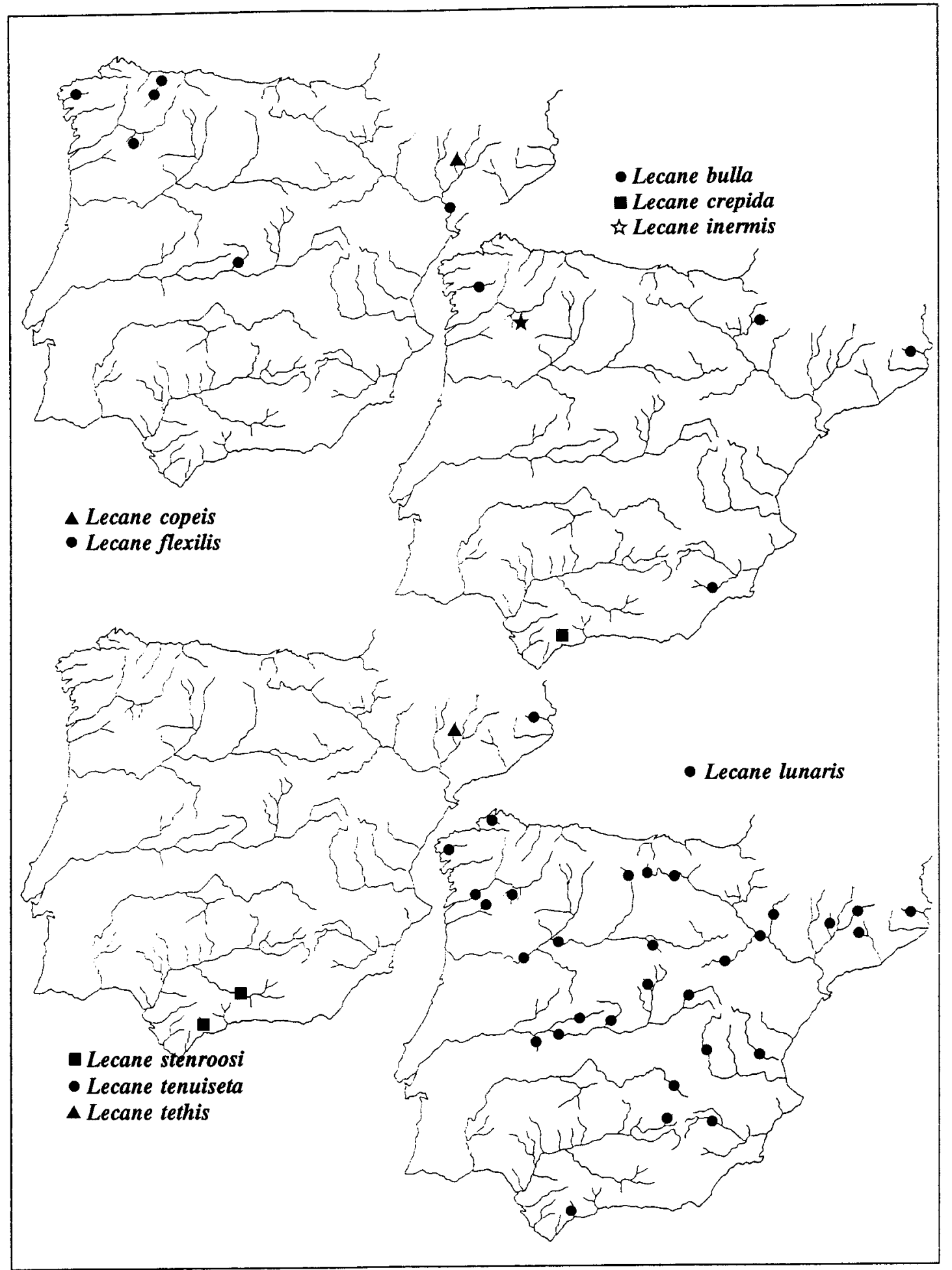

Figure 19. Distribution of some species of genus Lecane (survey 87/88). Distibución de algunas especies del género Lecane (estudio 87/88). 
Lecane (M.) hamata Stokes, 1896 (Fig. 18 b)

Monostyla hamata stokes, 1896; Lecane hamata, after Myers, 1937.

Ecology. Periphytic species, littoral. Eurytopa. Cond: $179.3-344 \mu \mathrm{S} \mathrm{cm}^{-1}$; Alk: 1507.6-2799 peq $\mathrm{I}^{-1}$; $\mathrm{pH}$ : 7.9; Temp: $11.9-13.5^{\circ} \mathrm{C}$

Morphologicalfeatures of interest. Head aperture with a dorsally narrow U-shaped sinus. Dorsally it presents a V-shaped sinus with two rounded in its posterior end cusps. The ventral plate is extended with two acute cusps on either side of the head aperture. The dorsal plate presents regular facetting. It has a transverse fold and several longitudinal folds on the ventral plate. It has one short and slender toe without claw.

Geographical distribution. Cosmopolite. Selga (1952) and De Ridder (1962) found it in waterbodies of the Iberian Peninsula. In the Balearic archipelago it is a common species; frequent in farm ponds and drinking troughs (De Manuel, et al. 1992).

Distribution in reservoirs. In the $1987 / 88$ survey it has been found in plankton samples from two reservoirs during the mixing period: Retortillo (69) and Boadella (79). In the 1972/75 survey it was found in winter and autumn, in five reservoirs, all of low mineralization.

Lecane (L.)hastata (Murray, 1913) (Fig. 17 g)

Cathypna hastata Murray, 1913; Lecane hastata, Harring \& Myers, 1926.

Ecology. Littoral species, often present in fresh and slightly brackih waters.

Cond: $541 \mu \mathrm{S} \mathrm{cm}^{-1}$; Alk: 3038 peq $\mathrm{l}^{-1}$; pH: 8.1; Temp: $24.3{ }^{\circ} \mathrm{C}$

Morphological features of interest. Head aperture margins not coincident; dorsal slightly convex, ventral straight. Two small spines at the external angles. Dorsal plate smaller than ventral, truncated posteriorly. Toes larger than a quarter of its total body length, terminating in a long acute claw.

Geographical distribution. Probably cosmopolite. It has been collected in waterbodies from Delta de l'Ebre (Forés et al. 1986) and in coastal ponds from Mallorca and Menorca (De Manuel et al. 1992).
Distribution in reservoirs. Rare. In the 1987/88 survey it was found in summer samples from Villalcampo (26).

Lecane (L.) inermis (Bryce, 1892) (Fig. 17 f; Fig. 19)

Distyla inermis Bryce, 1892; Lecane inermis, after Harring, 1913.

Ecology. Littoral species. Found mostly in warm waters, thermal springs, etc. (Kutikova, 1970, found it in a geyser environment at 62.5 "C).

Cond: $14.7 \mu \mathrm{S} \mathrm{cm}^{-1}$; Alk: 74.7 peq $\mathrm{l}^{-1}$; $\mathrm{pH}: 7.3$; Temp: $19.4^{\circ} \mathrm{C}$

Morphological features of interest. Membranous, very flexible lorica, anterior margins coincident; ventral plate wider than dorsal, both without ornamentation. Foot segment rounded, it projects beyond the dorsal plate. The second foot segment projects beyond the lorica. Toes are short, straight and terminated in an acute recurved claw almost as long as the toe.

Geographical distribution. Cosmopolite. Rare, in Spain it has previously been found by Margalef (1948, 1949) and Donner (1970).

Distribution in reservoirs. It has been found only in the reservoir Chandrexa (22) in the north east of the Iberian Peninsula and only during summer.

Lecane (L.) luna (Muller, 1776) (Fig. 17 d)

Cercaria luna Muller, 1776; Lecane luna, after Nitzsch, 1827.

Ecology. Littoral and periphytic species. Eurytopic, common in freshwater environments. Heleoplanktonic, frequently occurring in plankton samples.

Cond: $14.7-907 \mu \mathrm{S} \mathrm{cm} \mathrm{cm}^{-1}$; Alk: 74.7-3882 peq $\mathrm{l}^{-1}$; pH: 6.3-9.9; Temp: $9.5-26.2{ }^{\circ} \mathrm{C}$

Morphological features of interest. Head aperture margins not coincident: both with deep lunate sinuses. External angles of ventral sinus cusp-like, dorsal sinus angles more blunt. Smooth dorsal plate almost circular with a broad medium anterior hump. Ventral plate is slightly narrower with a single transverse fold. Toes are one third of the total body lenght, terminated in a claw with a basal spicule. 
Geographical distribution. Cosmopolite. It is a common, widespread lecanid.

Distribution in reservoirs. It has been found in plankton samples from 20 reservoirs, both in winter and in summer, distributed uniformly throughout the Iberian Peninsula.

Lecane (M.) lunaris (Ehrenberg, 1832) (Fig. 18 e; Fig. 19)

Lepadella lunaris Ehrenberg, 1832; Monostyla lunaris Ehrenberg, 1838.

Ecology. Littoral, it can be considered heleoplanktonic. This lecanid occurs frequently in the plankton. Eurytopic, it prefers eutrophic water.

Cond: 22-1126.3 $\mu \mathrm{S} \mathrm{cm} \mathrm{cm}^{-1}$; Alk: 98-4681.7 $\mu$ eq $\mathrm{I}^{-1} ; \mathrm{pH}: 6.3-9.2$; Temp: 7.2-26.2 "C

Morphological features of interest. Head aperture narrow dorsally, with a V-shaped sinus posteriorly rounded. Ventral margin wide, sinus deep. Transverse dorsal fold at base of anterior sinus; toe long and slender, more than a third of total body lenght, with two annular constrictions. Claw long, slender, acutely pointed with two minute basal spicules. Diverse morphs and varieties have been described (L. lunaris var. constricta, Murray, 1913; L. lunaris crenata, Harring, 1913; L. lunaris f. perplexa, Ahlstrom, 1938).

Geographical distribution. Cosmopolite. Widely distributed through all the Iberian Peninsula territory.

Distribution in reservoirs. It has been found in numerous reservoirs (31), distributed throughout Spain during stratified conditions and after mixing. In the previous survey it had been collected in plankton samples from 40 localities.

Lecane (L.)mira (Murray, 1913) (Fig. 17 b)

Cathypna mira Murray, 1913; Lecane mira after Harring \& Myers, 1926.

Ecology. Periphytic species; common in slightly acid waters. Rarely occurring in plankton.

Cond: $52 \mu \mathrm{S} \mathrm{cm}^{-1}$; Alk: $320.2 \mu \mathrm{eq} \mathrm{l}^{-1}$; $\mathrm{pH}$ : 7.2; Temp: $10.8^{\circ} \mathrm{C}$

Morphologicalfeatures of interest. Head aperture margins not coincident: dorsal almost straight, ventral slightly concave; two stout trian- gular cusps at external angles. Dorsal plate indistinctly facetted, with anterior row incomplete. Ventral plate with transverse fold; second foot segment visible beyond posterior segment; toes are about a quarter of total body length and terminate in stout claw with a basal spicule.

Geographical distribution. Cosmopolite. Mainly found in the Pyrenean mountains (Margalef, 1948b; unpublished data).

Distribution in reservoirs. It has been only found in the reservoir Salime (10), during mixing period.

Lecane (M.) scutata (Harring \& Myers, 1926) (Fig. $18 \mathbf{g}$ )

Monostyla scutata Harring \& Myers, 1926; Lecane scutata Wiszniewski, 1954

Ecology. Littoral periphytic species. Koste \& Shiel (1990a) recorded it is an acidophil species, common among Sphagnum, but it is probably more eurytopic.

Cond: $550.6 \mu \mathrm{S} \mathrm{cm}^{-1}$; Alk: $3468 \mu \mathrm{eq} \mathrm{^{-1 }}$; $\mathrm{pH}$ : 8.3; Temp: 8.4 "C

Morphological features of interest. Head aperture margins coincident, slightly concave; with sharp corners but no anterior spines. Lateral sulci are shallow, indistinct transverse fold of ventral plate; toe long, stout, of one third of the total body length and parallel-sided then tapering to a lender acute claw.

Geographical distribution. Cosmopolite. Rare, in Spain it has only been collected in ponds in South-East Spain (Rojo \& Oltra, 1986) and in reservoirs.

Distribution in reservoirs. Rare. It has been found only in winter samples from Entrepeñas (37). In the 1972/75 survey it was collected in four localities.

Lecane (M.) stenroosi Meissner, 1908 (Fig. 18 h,i; Fig. 19)

Monostyla bicornis Stenroos, 1898; Monostyla stenroosi Meissner, 1908; Lecane stenroosi Wiszniewski, 1953.

Ecology. Littoral and periphytic species. Abundant in algal mats in ephemeral ponds (Koste \& Shiel, 1990a). Warm stenoterm. 
Cond: 383-1 175.6 $\mu \mathrm{S} \mathrm{cm}^{-1}$; Alk: 2251.3-3882 peq $\mathrm{I}^{-1}$; pH: 8-8.8; Temp: $23.3-26.2^{\circ} \mathrm{C}$

Morphological features of interest. Head aperture dorsally straight, ventrally with shallow rounded sinus with strongly convex sides. Two short stouts, incurved hooklike frontal spines. Lateral sulci very deep, particularly in anterior half, with characteristic constriction in ventral plate. Toe is long, stout, about one third of the total body length, slightly enlarged in middle. Claw is short, stout and acutely pointed, with two basal spicules.

Geographical distribution. Cosmopolite. Found by Wiszniewski (1931) and Arévalo (1932) in waterbodies in València (Central Mediterranean coast of Spain).

Distribution in reservoirs. Found in summer samples from La Concepcidn (102) and Iznajar (73). In the previous survey it was not found.

Lecane (L.)tenuiseta Harring, 1914 (Fig. 17 e) Ecology. Littoral species. Eurytopic.

Cond: $344 \mu \mathrm{S} \mathrm{cm}^{-1}$; Alk: $2799 \mu \mathrm{eq} \mathrm{l}^{-1}$; $\mathrm{pH}: 7.9$; Temp: $13.5^{\circ} \mathrm{C}$

Morphologicalfeatures of interest. Head aperture margins parallel, slightly convex; dorsal plate smooth, rounded posteriorly; ventral plate with a series of ridges. Lateral sulci are shallow; posterior segment broad, rounded, it protrudes beyond the dorsal plate. The second foot segment is not protruding. The toes are long, slender, approximately one third of the total body length, terminating in extremely long spine-like claws.

Geographical distribution. Cosmopolite. Rare, it is a new record for the Spanish rotifer fauna. It has also been collected in lake Sanabria (unpublished data).

Distribution in reservoirs. Scarcity in the reservoir Boadella (79), in samples from the stratification period.

Lecane (M.) tethis Harring \& Myers, 1926 (Fig. 19)

Ecology. Periphytic species. It is a rare organism. Little autoecological information is available in the literature. Koste (1978) included it as a synonymous of $L$. (M.)furcata, but they probably are two separate species, as there are considerable differences between the morphology of the lorica, specifically, in the distal part of the foot.

Cond: $449.7 \mu \mathrm{S} \mathrm{cm}^{-1}$; Alk: 2773 peq $\mathrm{l}^{-1} ; \mathrm{pH}$ : 8.3; Temp: $20.5^{\circ} \mathrm{C}$

Morphological features of interest. Head aperture with coincident straight dorsal and ventral margins; regular facetting of dorsal plate; ventral plate also with longitudinal markings. Transverse fold in front of foot with two small semicircular folds. Toe long, one third of total body length, straight with slight taper. Claw long and slender, with a medium line.

Geographical distribution. Cosmopolite. Rare, it is a new record for the rotifer fauna of the Iberian Peninsula.

Distribution in reservoirs. Only one specimen was collected in summer samples from the reservoir Sant Ponç (96).

\section{Family PKOALIDAE \\ Genus Proales Gosse}

Proales fallaciosa Wulfert, 1937 (Fig. 20 a,b,c; Fig. 16)

Ecology. Heleoplanktonic species. Eurytopic, it prefers dystrophic ponds. It tolerates wide ranges of alkalinity, and may inhabit slightly acid waters too. It feeds on detritus, bacteria, algae, and microcrustacea and other invertebrates in decomposition (Koste \& Shiel, 1990b).

Cond: $208.8 \mu \mathrm{S} \mathrm{cm}^{-1}$; Alk: 1516.2 peq $\mathrm{l}^{-1} ; \mathrm{pH}$ : 8.39; Temp: $18.84^{\circ} \mathrm{C}$

Morphological features of interest. Body cylindrical (200 a $300 \mu \mathrm{m})$ without lorica, with medial bulge. It presents a soft and flexible cuticle, with longitudinal folds. Small rounded knob projecting dorsally between toes. Oblique corona. Small rostrum present. Virgate trophi, with seven teeth in left uncus, right with 5-6 teeth. Manubrium presents a wide lamella. Gastric glands are round to elongated. Foot glands with reservoirs. It may be confused with Proales decipiens, however the latter presents a different trophy structure, and does not has the characteristic dorsal knob between toes. 


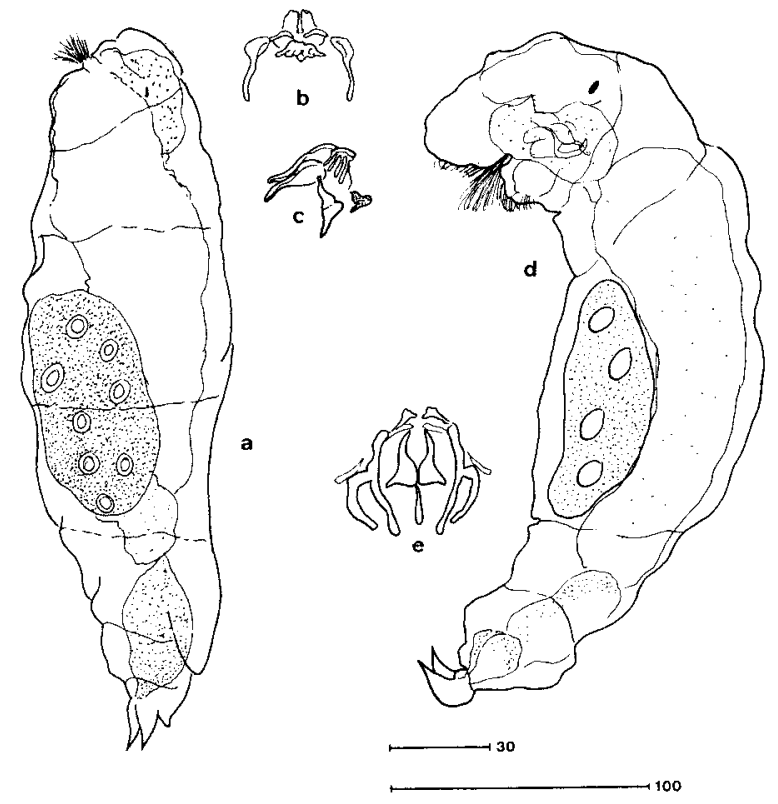

Figure 20. a,b,c, Proales fallaciosa Wulfert, found in Camarasa. a, contracted animal; b. lateral and c. sagital view of mastax. d,e, Lindia annecta Harring \& Myers, found in As Conchas. d, contracted animal; e, frontal view of mastax. Scale in $\mu \mathrm{m}$ (smaller scale bar for mastax). $a, b, c$, Proales fallaciosa Wulfert, de Camarasa. a, especimen contraido; $b, c$ vista lateral y sagihal del mastax. d,e, Lindia annecta Harring \& Myers, de As Conchas. d, especimen contraido; $e$, vista frontal del mastax. Escala en $\mu$ m (escala pequeña para el mastax).

Geographical distribution. Cosmopolite. Rare, specimens collected from reservoirs are the first records of this species for the Iberian Peninsula (also inhabits Pyrenean lakes, unpublished data).

Distribution in reservoirs. (Fig. 15). It has been collected in the reservoir Camarasa (94) during the stratification period. This species is more common in Pyreenes and had probably colonized the reservoir from resting eggs carried down by running water.

\section{Family LINDIIDAE}

Genus Lindia Dujardin (Fig. 4. 15; 20 d,e)

Lindia annecta Harring \& Myers, 1922

Ecology. Periphytic species are common. It is rarely found in plankton, probably as a migrant.
Typical of Sphagnum bogs, it prefers low mineralized and slightly acid waters.

Cond: $51.5 \mu \mathrm{S} \mathrm{cm}^{-1}$; Alk: $171 \mu \mathrm{eq} \mathrm{l}^{-1}$; $\mathrm{pH}: 6.8$; Temp: $7.85^{\circ} \mathrm{C}$

Morphological features of interest. Body slender (300 a $350 \mu \mathrm{m})$, transparent. Transverse folds give annular appearance. Head and neck sections are of similar length and width. The corona presents two small lateral auricles. It has two short conical and acute toes. Trophi virgate. Fulcrum short, quadrate. Manubria with wide lamellae, before hooked appendage (Fig. 19 e). Uncus with three teeth.

Geographical distribution. (Fig. 16). Probably cosmopolite. Rare. Lindia annecta is the first record for the Iberian peninsula.

Distribution in reservoirs. It has been found, in winter, in As Conchas (20).

Family NOTOMMATIDAE

Genus Cephalodella (Bory de St. Vincent)

Cephalodella forficula Ehrenberg, 1932 (Fig. 21 a)

Distemma forficula Ehrenberg, 1932; Cephalodella forficula, after Harring, 1913.

Ecology. Littoral species, generally inhabitant of small waterbodies. Occasionally in plankton. It prefers slightly acid water, but it also may occur in alkaline environments.

Cond: $435.5 \mu \mathrm{S} \mathrm{cm}^{-1}$; Alk: $3545 \mu \mathrm{eq}^{-1}$; $\mathrm{pH}$ : 8.2; Temp: $18.8^{\circ} \mathrm{C}$

Morphological features of interest. Elongate, spine-shaped body, slight constriction at neck; integument flexible, without lorica plates. Toes short, stout, recurved, about one fifth of the total body length. Toes have a distinctive transverse spicule row (2-4) on the dorsal median surface, terminating in a long spine. This character identified and distinguished $C$. forficula from other species .

Geographical distribution. Probably cosmopolite. In Iberian Peninsula it has rarely been recorded, but it is probably more common than records suggest. It has been found in the Balearic archipelago (De Manuel et al., 1992) and in Pyrenean lakes (unpublished data). 

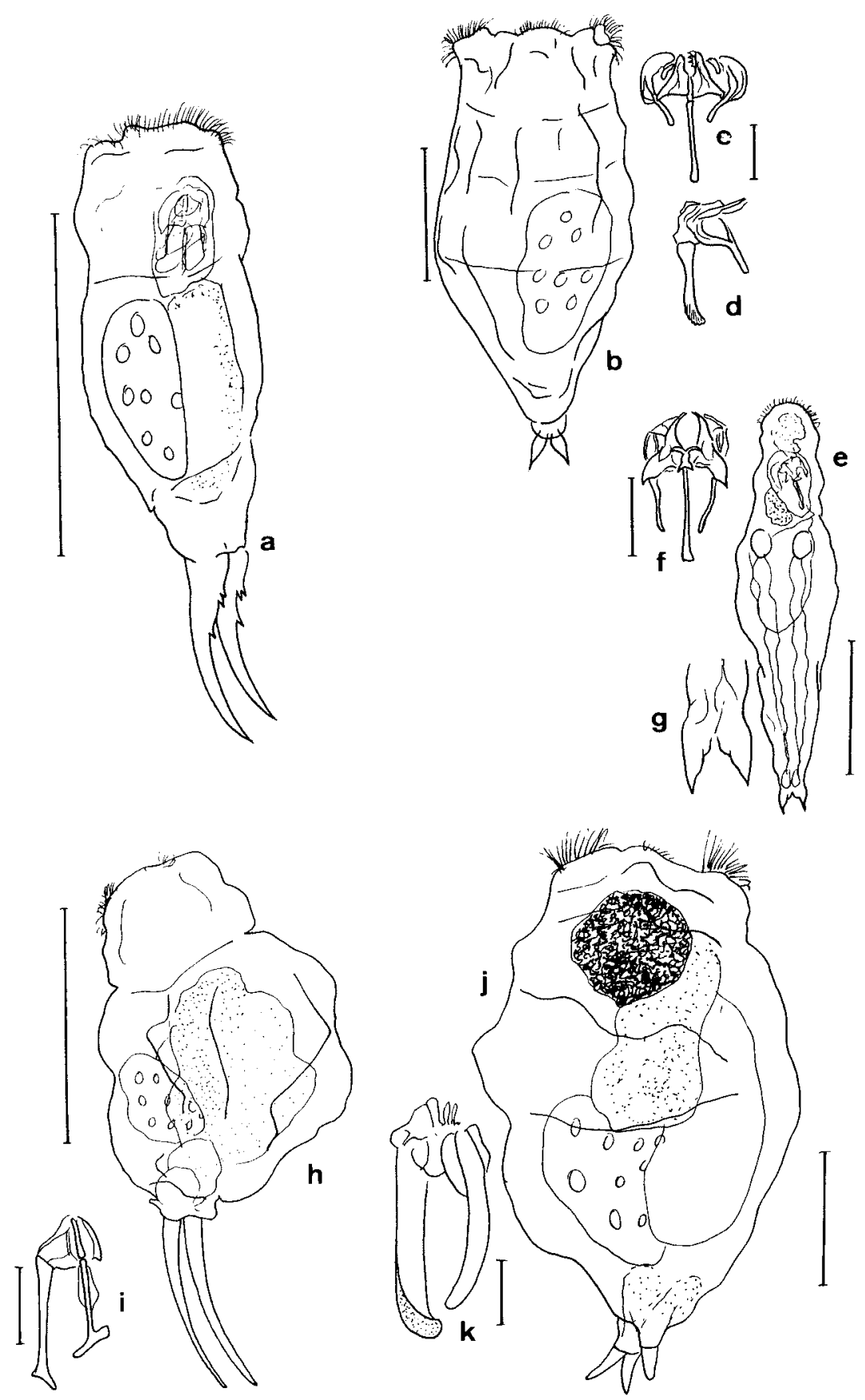

Figure 21. a, Cephalodella forficula, from Sobrón; b-d, Notommata cerberus, b, contracted animal, c, d, mastax, from Sobrón; e-g, Resticula nyssa, e, contracted animal, $\mathrm{f}$, mastax, g, detail of foot; h-i, Cephalodella gibba, $\mathrm{h}$, contracted animal, i, mastax; $\mathbf{j}, \mathrm{k}$, Notommata copeus, $\mathrm{j}$, contracted animal, k, mastax, from Mao. Body scale bar: $100 \mu \mathrm{m}$; Mastax scale bar: $20 \mu \mathrm{m}$. a, Cephalodella forficula, de Sobrón; b-d, Notommata cerberus, b, especímen contraido, $c$, d, mastax, de Sobrón; e-g, Resticula nyssa, e, especímen contraido, $f$, mastax, $g$, detalle del pie; $h$-i, Cephalodella gibba, $h$, animal contraido, $i$, mastax; $j, k$, Notommata copeus, $j$, animal contraido, $k$, mastax, de Mao. Escala corporal: $100 \mu m$; Escala del mastax: $20 \mu m$ 
Distribution in reservoirs. It has been found in reservoir Sobron (91), in summer.

Cephalodella gibba Ehrenberg, 1832 (Fig. 16; Fig. $21 \mathrm{~h}, \mathrm{i})$

Furcularia gibba Ehrenberg, 1932; Cephalodella gibba, after Harring \& Myers, 1924.

Ecology. Heleoplanktonic species, common the littoral areas of fresh and brackish waterbodies. It may occasionally be found in the branquial chambers of some crustaceans. It feeds on unicellular algae, flagellates and ciliates. It is an eurytopic species, but it prefers cold waters

Cond: $19.7-950 \mu \mathrm{S} \mathrm{cm}^{-1}$; Alk: 98.6-3667 peq $\mathrm{l}^{-1}$; pH: 6.6-8.48; Temp: $6.4-18.8^{\circ} \mathrm{C}$

Morphological features of interest. Body slightly elongated, compressed laterally, gibbous rump. Lorica with distinct plates. Toes long, straight or recurved, slender and of one third of the body length. Mastax large, with manubrium strongly crooked, hammer-shaped (Fig. 21 i).

Geographical distribution. Cosmopolite. It has been found throughout the Iberian Peninsula.

Distribution in reservoirs. It is a relatively common organism in plankton samples of reservoirs. In the 1972/75 survey this species was collected in 22 reservoirs. In the 1987/88 survey it has been found in 11 reservoirs (Fig. 16), mostly in winter (mixing period).

Notommata cerberus (Hudson \& Gosse, 1886) (Fig. 21 b-c)

Copeus cerberus Hudson \& Gosse 1834; Notommata cerberus, after de Beauchamp (1908)

Ecology. Littoral periphytic species. Omnivore, it feeds on rotifers, desmidiaceae, diatoms and flagellates. It was initially considered as an acidophyl species.

Cond: $435.5 \mu \mathrm{S} \mathrm{cm}^{-1}$; Alk: $3545 \mu \mathrm{eq} \mathrm{^{-1 }} ; \mathrm{pH}$ : 8.2; Temp: 18.8 "C

Morphological features of interest. Body slender (300-600 $\mu \mathrm{m})$, integument flexible; slight transverse folds between head and neck. Tail rounded, with median lobe and rudimentary lateral lobes. Toes slender, pointed and short. Mastax virgate, Y-shaped lamellae at base of ful- crum; rami asymmetric, inner edges striate but not denticulate. Eyes not large and lenticular.

Geographical distribution. Cosmopolite. This is the first record for Iberian rotifer fauna.

Distribution in reservoirs. It was collected in Sobrón (99), during the summer campaign of the $1877 / 88$ survey.

Notommata copeus Ehrenberg, 1834 (Fig. $21 \mathrm{j}, \mathrm{k})$

Notommatus copeus Ehrenberg, 1834.

Ecology. Littoral species, occasional in plankton. It feeds on filamentous algae (Spyrogira, Zygnema, Mougeotia). It prefers slightly acid waters.

Cond: $20 \mu \mathrm{S} \mathrm{cm}^{-1}$; Alk: 99 peq $\mathrm{l}^{-1}$; $\mathrm{pH}: 7$; Temp: $6{ }^{\circ} \mathrm{C}$

Morphological features of interest. Large species (500-1000 $\mu \mathrm{m})$, elongate body, truncated posteriorly. Tail with a conical projection with an articulated tip-segment. Foot with two broad segments. Very long ciliate auricles. Long setae on lateral antenna. Mastax virgate, asymmetric, left side more developed

Geographical distribution. Cosmopolite. It is the first record for the Iberian fauna.

Distribution in reservoirs. Only one specimen was collected in the reservoir Mao (99), in winter.

Resticula nyssa Harring \& Myers, 1924 (Fig. $21 \mathrm{e}-\mathrm{g})$

Ecology. Littoral species, periphytic. It prefers low mineralized and slightly acid waters.

Cond: $435.5 \mu \mathrm{S} \mathrm{cm}^{-1}$; Alk: $3545 \mathrm{peq} \mathrm{l}^{-1} ; \mathrm{pH}$ : 8.2; Temp: 18.8 "C

Morphologicalfeatures of interest. Vermiform body (300-630 pm), with longitudinal and transverse striae. Anterior protusion on head corresponds to the rostrum of other taxa. Foot is jointed, very short and broad. Toes are short, with a bulbous basal enlargement, and a type claw. Modified virgate mastax. Fulcrum long. Rami triangular with large asymmetric alulae. Basal apophysis prominent (Fig. 21 f).

Geographical distribution. Probably cosmopolite. It is a new record for the Iberian rotifer fauna. 


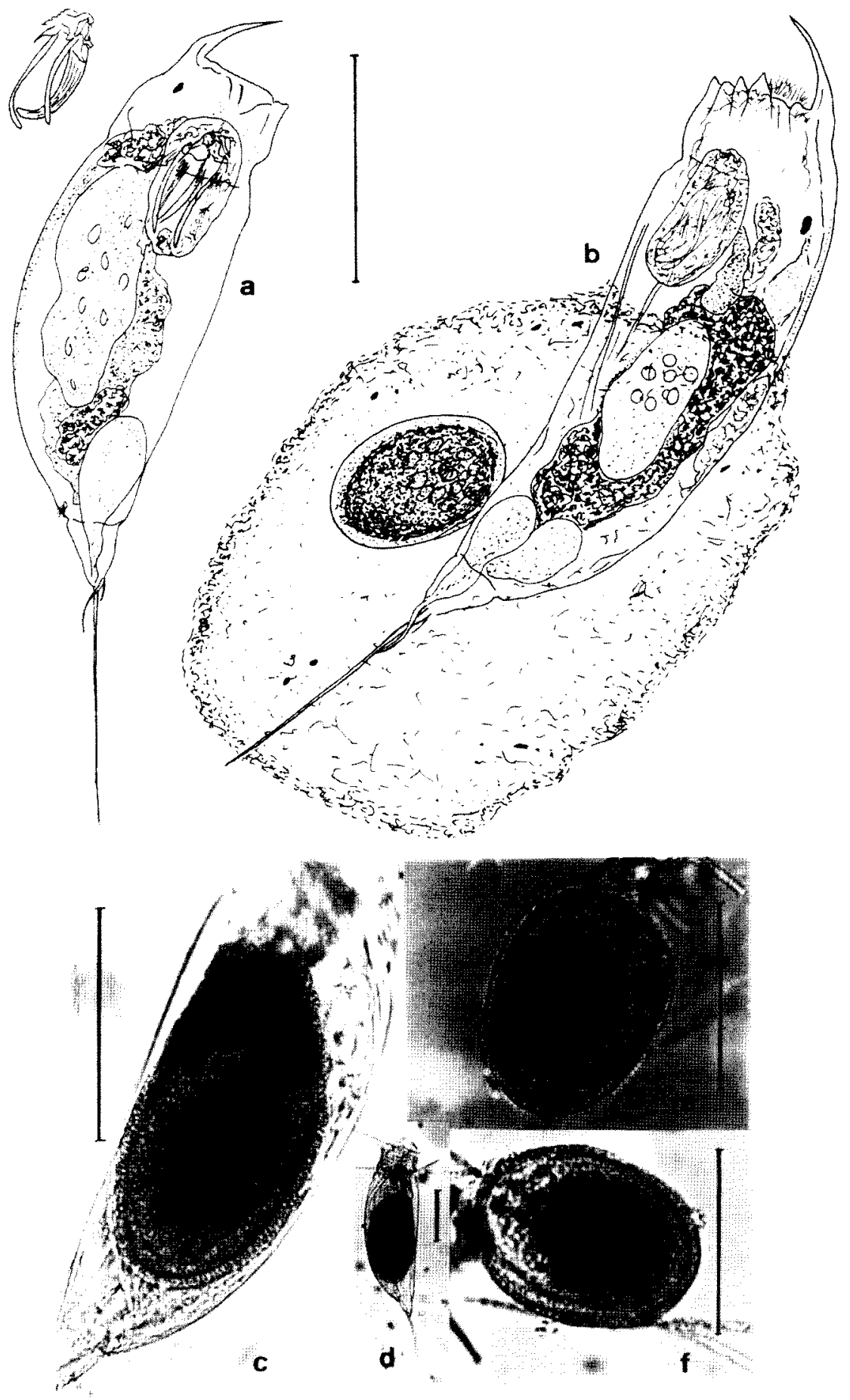

Figura 22. Trichocerca cylindrica: a, lateral view and mastax, from San Esteban; b, gelatinous mass and animal with amictic egg, from Forcadas; c, d, photographs of an individual with resting eggs, from Cazalegas; e, f, resting eggs from plankton from Cazalegas. All scale bars are $100 \mu \mathrm{m}$ long. Trichocerca cylindrica : a, vista lateral y mástax, de San Esteban; b, masa gelatinosa, animal y huevo amictico, de Forcadas; $c, d$, fotografia de un especimen con huevos durables, de Cazalegas; e, f, huevos duravbles del pláncton de Cazalegas. Escala: 100 um. 
Distribution in reservoirs. Found in summer samples from Sobrón (91), in the basin of the river Ebre.

\section{Family TRICHOCERCIDAE}

Genus Trichocerca Lamarck

Trichocerca cylindrica (Imhof, 1891) (Fig. 22; Fig. 23)

Mastigocerca cylindrica Imhof, 1891; Trichocerca cylindrica, after Harring, 1913.

Ecology. Euplanktonic species. Warm stenoterm, it prefers low calcium concentrations. This is the only species of the genus that carries asexual eggs from hatching. Phytofagous, it feeds on algae, preferentially Crisophycea (Pourriot, 1970).

Cond: $14.75-3720 \mu \mathrm{S} \mathrm{cm} \mathrm{cm}^{-1}$; Alk: 74.7-3038 peq $\mathrm{l}^{-1}$; pH: 7.2-9.6; Temp: 9.5-26.1 ${ }^{\circ} \mathrm{C}$

Morphological features of interest. Elongate, cylindrical body. It presents a very fine, and ventrally-curved acute spine on the median dorsal margin of the lorica. Longitudinal striae in head region with short keel and striates field. Left toe as long as body, right toe reduced to rudimentary. Animal occasionally in gelatinous sheath (Fig. 22,b). Eggs carried attached to parent. Males are toeless.

A population from reservoir Cazalegas were observed with large resting eggs (Fig. $22 \mathrm{c}$-f), of approximately $120 \mu \mathrm{m}$ present both in side the animals and detached too. Koste (1978) included Trichocerca chattoni (Beauchamp, 1907). A warm stenoterm, as a variety of 7: cylindrica (7: cylindrica chattoni). Size is the main difference between the two taxa and, indeed it maybe a case of cyclomorphosys. Guiset (1976) called this species.

Geographical distribution. Cosmopolite if both taxa are considered a unique species (i.e. 7: cylindrica has holarctic distribution; T. cylindrica chattoni is pantropical and pansubtropical). It is found mostly in the western regions of the Iberian Peninsula.

Distribution in reservoirs. In the 1987/88 survey it has been found in 21 localities (only 19 in summer). Frequent in reservoirs in the NW of the
Iberian Peninsula and in the basin of the river Guadalquivir (Fig. 23).

Trichocerca porcellus (Gosse, 1886) (Fig. 23; Fig. 24 e,f)

Diurella tigris Bory de St. Vincent, 1824; Monocerca porcellus Gosse, 1886;Coelopus porcellus, Hudson \& Goose, 1886; Rattulus tigris Stenroos, 1898; Diurella orceklus, Jennings, 1903.

Ecology. Heleoplanktonic species, it is preferentially found in oligosaprobic waters. It lays its eggs inside algae (Aglaucoseria, Fragillaria and Dinobryon).

Cond: $92 \mu \mathrm{S} \mathrm{cm}^{-1}$; Alk: 332.6 peq $\mathrm{l}^{-1}$; $\mathrm{pH}$ : 7.1; Temp: $9.5^{\circ} \mathrm{C}$

Morphological features of interest. Short, plump, distinctly curved body. Head sheath separated by constriction. Two anterior dorsal cusps, the right one slightly curved. Two toes, the left longer, the right shorter, usually held against ventral abdomen. When the animal is preserved and contracts, cephalic margin may resemble the head of a "little pig". Trophi is strongly asymmetric, with left manubrium robust and crooked. The left ramus presents an alula that is much longer than the right one. The specimens live longer in alkaline than in acid waters. The species may be confused with T. musculus, but the mastax presents differential features (Shiel \& Koste, 1992).

Geographical distribution. Cosmopolite. It has previously been found in SE Spain by Rojo \& Oltra (1986). One would expect a wider distribution.

Distribution in reservoirs. It has been found in Forcadas (13), in winter.

Trichocerca pusilla (Lauterborn, 1898)

Mastigocerca pusilla, Lauterborn, 1898; Rattulus pusillus Jennings, 1903; Trichocerca pusilla, after Harring, 1913.

Ecology. Heleoplanktonic species. Eurytopic, may be found in a wide range of salinities. Some species of the genus Brachionus occasionally have subitaneous eggs fixed in the lorica. It may suck the contend of the eggs of other plankton rotifer species (Pourriot, 1970). 

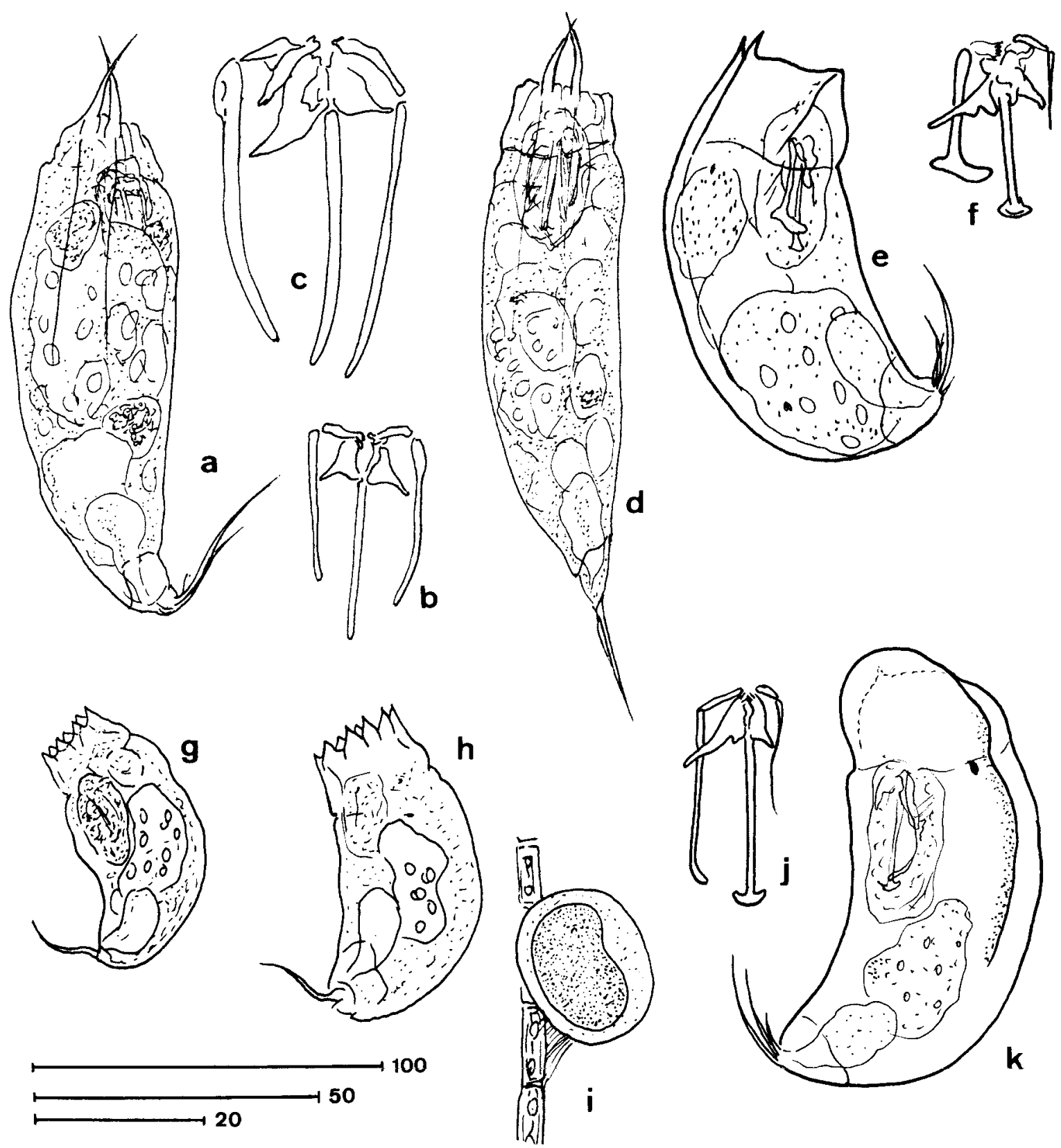

Figure 24. Some Trichocerca species found in plankton samples from Spanish reservoirs during the $87 / 88$ survey. Scale bars in $\mu \mathrm{m}$ ( $100 \mu \mathrm{m}$ for micrographs of bodies, $50 \mu \mathrm{m}$ for mastax, 20 for mastax c). a-d, T. similis, a,b from Velle, c,d, from San Esteban; e, f, T. porcellus, from Forcadas; g-i, T, rousseletti, from Salime, i, amictic egg in Aulacoseira granulata; $\mathrm{j}, \mathrm{k} T$. vernalis, from Burguillo. Algunas especies de Trichocerca identificadas en los embalses españoles (estudio 87/88). Escala lineal en $\mu m$ (100 para el cuerpo, 50 par el mastax, 20 para el mastax c). $a-d$. T. similis, $a, b$ de Velle, $c, d$, de San Esteban; $e, f$, T. porcellus, de Forcadas; $g-i$, T. rousseletti, de Salime, $i$, huevos amicticos en Aulacoseira granulata; $j, k$ T. vernalis, de Burguillo. 
Cond: 44-932 $\mu \mathrm{S} \mathrm{cm}{ }^{-1}$; Alk: 273-2353.25 $\mu$ eq $\mathrm{l}^{-1}$; $\mathrm{pH}$ : 7.2-9.6; Temp: $10-26.2^{\circ} \mathrm{C}$

Morphological features of interest. Small pyriform to fusiform body $(70-120 \mu \mathrm{m})$, Left toe slightly shorter than body. Red eye dorsal to brain. Asymmetric mastax; rami with robust, outwardly directed alulae; left manubrium weakly curved, right manubrium shorter.

Geographical distribution. Cosmopolite. Found in numerous mainland localities. It is probably widespread throughout the Iberian Peninsula.

Distribution in reservoirs. Occasionally found in plankton samples from reservoirs, both in sum- mer and in winter. In the $1987 / 88$ survey it was found in six reservoirs.

Trichocerca rousseleti (Voigt, 1902) (Fig. 23; Fig. 24 g-i)

Coelopus rousseleti Voigt, 1901; Mastigocerca minima, Skorikov, 1913; Diurella rousseleti Jennings, 1903.

Ecology. Euplanktonic species, cold stenoterm. Often associated to algae blooms of Aglaucoseria; sometimes $T$. rousseleti attaches its eggs to the cells of this diatom genus (Fig. $24 \mathrm{i}$ ).

Cond: 48.2-84.6 $\mu \mathrm{S} \mathrm{cm}-1$; Alk: 255-502 $\mu$ eq $\mathrm{l}^{-1}$; pH: 7-7.2; Temp: 9.6-11.4 ${ }^{\circ} \mathrm{C}$

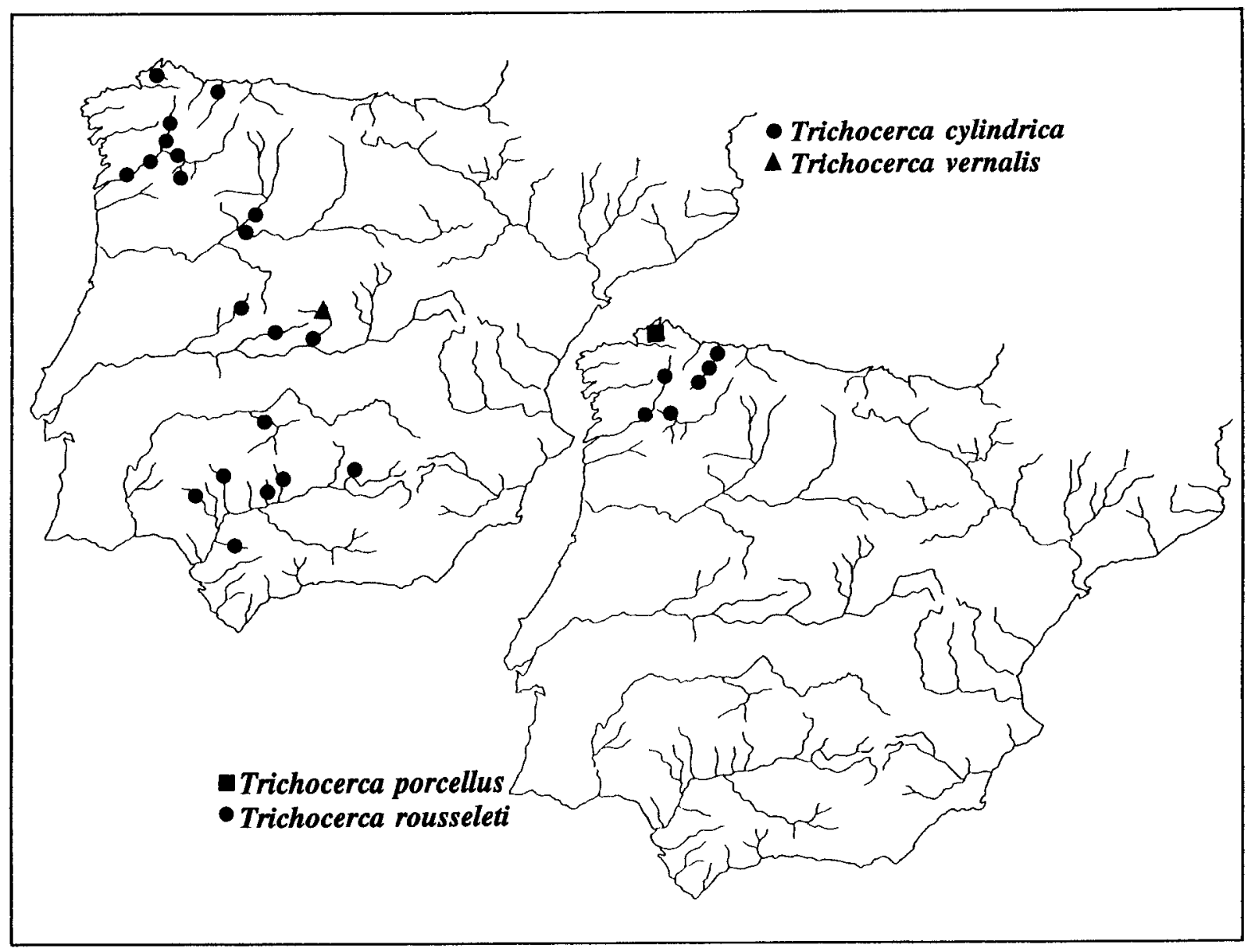

Figure 23. Distribution of some species of the genus Trichocerca (survey 1987/88). Distribución de algunas especies del género Trichocerca (estudio 87/88). 
Morphological features of interest. Squared body, with arched dorsum. Anterior lorica margin with 8-9 projecting serration. Head clearly distinguished by transverse suture. Right toe about one half of the left, slender, easily overlooked. May be confused with $T$. stylata, but $T$. rousseleti is slightly shorter and the ramus presents a bifurcate alulae.

Geographical distribution. Probably cosmopolite. In Spain it has only been collected in reservoirs and in Pyrenean lakes (Miracle, 1978).

Distribution in reservoirs. It has been found in winter, in six reservoirs from the northwest Spain (Fig. 23).

Trichocerca similis (Wierzejski, 1893) (Fig. 23; Fig. 24 a-d)

Coelopus similis Wierzejski, 1893; Rattulus bicornis, Western, 1893; Mastigocerca wolgensis Meiszner, 1902; Mastigocerca heterostyla Daday, 1903.

Ecology. Planktonic species. It seems to prefer warmer waters. Its feeds on cryptomonadaceae and chrysophyceae, specially Mallomonas and Dinobryon (Pourriot, 1970). T. similis attaches its asexual eggs to other plankters. It is a common prey of predators rotifers as Asplanchna and Ploesoma (Guiset, 1977c).

Cond: $14.7-5326.6 \mu \mathrm{S} \mathrm{cm}{ }^{-1}$; Alk: 74.7-3882 peq $1^{-1}$; pH: 7-9.63; Temp: 9.53-26.2 ${ }^{\circ} \mathrm{C}$

Morphological features of interest. Fusiform body. Head sheath marked by distinct suture. Two characteristic slender, unequal occipital spines; two low keels extend back from spines. Foot with two unequal toes, about one third of total body length.

Geographical distribution. Probably cosmopolite. In the Iberian Peninsula it is widespread. It is also common in the Balearic archipelago (De Manuel et al., 1992).

Distribution in reservoirs. It is the most common species of the genus Trichocerca collected in Spanish reservoirs. In the 1987/88 survey it was found in 38 samples (preferentially in summer), corresponding to 35 localities. In the 1972/76 survey it was collected in 41 reservoirs, though rarely in the Duero and Ebre river basins.
Trichocerca stylata (Gosse, 1851)

Monocerca stylata Gosse, 1851; Diurella stylata Eyfert, 1878; Mastigocerca stylata Hudson \& Goose, 1886; Rattulus stylatus Jennings, 1903; Trichocerca

stylata after Harring, 1913.

Ecology. Planktonic species. Found in small waterbodies, but also in lakes and reservoirs. Occasionally this species may attach subitaneous eggs onto other planktonic rotifers. As well as $T$. pusilla, this species also feeds on the eggs of other planktonic rotifers (Pourriot, 1970).

Cond: $27 \mu \mathrm{S} \mathrm{cm}^{-1}$; Alk: 107.3 peq $1^{-1}$; pH: 7.1; Temp: 6.4 "C

Morphological features of interest. Body irregular in form, integument very flexible. Foot about one half of total body length. Trophi asymmetric, fulcrum hammer-shaped and left manubrium larger than right. May be easily confused with $T$. Pusilla. Indeed Ruttner-Kolisko, (1974) suggests that both are forms of the same species.

Geographical distribution. Cosmopolite. It has only been collected in the north-east of the Iberian peninsula by Margalef (1948a), and more recently also in artificial waterbodies in Menorca (De Manuel et al. 1992).

Distribution in reservoirs. It has been found in winter in El Vado (38) and in summer in Mao (99).

Trichocerca vernalis Hauer, 1936 (Fig. 23; Fig. $24 \mathrm{j}, \mathrm{k})$

Diurella vernalis Hauer, 1936; Trichocerca vernalis, after Wiszniewski, 1954.

Ecology. Periphytic species, occasionally found in the plankton. Rare, it may be found in ephemeral ponds, but also in reservoirs.

Cond: $47 \mu \mathrm{S} \mathrm{cm}^{-1}$; Alk: 385 peq ${ }^{-1}$; pH: 7.3; Temp: $7.37^{\circ} \mathrm{C}$

Morphological features of interest. Squat, vaulted to conical body. Left anterior margin with large rounded plate. Foot and toes curved forward. Asymmetric trophi, with a relatively big left manubrium, "hoquey-stick"-shaped; right manubrium small, fragile and thin. Details of the mastax help distinguish it from $T$. brachiura (Gosse). 
Geographical distribution. Cosmopolite. It is a new record for the Iberian fauna.

Distribution in reservoirs. Several specimens were identified from winter samples of Burguillo (42), a reservoir located in the basin of the river Tajo.

\section{Family GASTROPODIDAE \\ Genus Ascomorpha Perty}

Ascomorpha ecaudis (Perty, 1850) (Fig. 25 c; Fig. 26); Sacculus viridis Bergendal, 1851; Ascomorpha helvetica Perty, 1852; Ascomorpha germanica, Leydig, 1854.

Ecology. Planktonic species, occasionally present in periphyton. It prefers warm waters and is more abundant in spring and autumn. According to Pourriot (1965), it feeds on flagellate algae (Chlamidomonas, Trachelomonas, Cryptomonas). Stemberger (1987) noted the importance of the mucus mass for catching food. This mass is found surronding the animal (may be $1 \mathrm{~mm}$ in diameter, but is usually absent in preserved material). Food caught in the mucus is carried to the mouth thanks to a current caused by cilia movement. Mucus also gives protection from some predators. A. ecaudis may have symbiotic algae (Zoochlorella) within stomach wall cells.

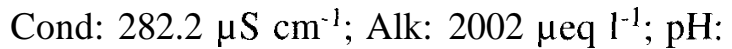
8.14; Temp: $25.10^{\circ} \mathrm{C}$

Morphological features of interest. It is characterized by the presence of four faecal bags forming a square. No apical tentacle. Spiny resting eggs. The analysis of a mastax is necessary to distinguish $A$. ecaudis from other species of the genus. Rami allules are triangular, with characteristic acute margins.

Geographical distribution. Probably cosmopolite. Frequent in Pyrenean lakes (unpublished data). Rare.

Distribution in reservoirs. A. ecaudis has only been found in La Minilla (84) in both surveys. Its presence in La Minilla constitutes the Southernmost record of this species in the Iberian peninsula.

Ascomorpha ovalis (Bergendal, 1892) (Fig. 25 d; Fig. 26)
Anapus ovalis Bergendal, 1892; Chromogaster testudo Lauterborn, 1893; Ascomorpha testudo Zacharias, 1894; Anapus testudo Weber, 1898; Ascomorpha ovalis, after Carlin, 1943.

Ecology. Planktonic species frequent in lakes and ponds. It prefers alkaline and bicarbonated water. It feeds on dinoflallegates, especially Ceratium. Its maxima coincides with those of Ceratium (Ruttner- Kolisko, 1974).

Cond: $-1107 \mu \mathrm{S} \mathrm{cm}$; Alk: 321.3-3711.2 $\mu$ eq $1^{-1}$ : pH: 7.8-9.3; Temp: $24.8-10^{\circ} \mathrm{C}$

Morphologicalfeatures of interest. Lorica constituted by two plates. Ventral plate oval. Variable number of accretion bodies and chromatophores in stomach wall. Trophi stylet-shaped, with hypofarinx for sucking the contents of Ceratium cells. Attachment to algae is done with a sickle-shapedpalp.

Geographical distribution. Cosmopolite. Widespread in Spain.

Distribution in reservoirs. It was found to be widespread in Spanish reservoirs, especially in summer. More frequent in the East where waters are typically of moderate to high alkalinity.

Ascomorpha sultans Bartsch, 1870 (Fig. 25 e; 26)

Sacculus hyalinus Kellicott, 1888; Ascomorpha agilis Zacharias, 1893; Ascomorpha hyalina, Jennings, 1901.

Ecology. Planktonic species, inhabiting pelagic and littoral environments. More frequent in summer and autumn. Like A. sultans, its abundance is associated to the developing of Ceratium. According to Pourriot (1976), it also feeds on Uroglena and peridinidae. A. saltans cooccurred in seven localities with $\boldsymbol{A}$. ovalis (Fig. 25 ), in spite of the fact this last species inhabits more alkaline environments.

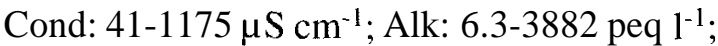
pH: 6.6-9.3; Temp: $6.4-26.7^{\circ} \mathrm{C}$

Morphological.features of interest. It presents one large fecal sac (i.e. accretion body). Trophi with well developed manubrium. Like $A$. ovalis, it presents a palp in the apical field. Chromatophores in stomach wall cells.

Geographical distribution. Cosmopolite. In Spain it is common in reservoirs, but there are 

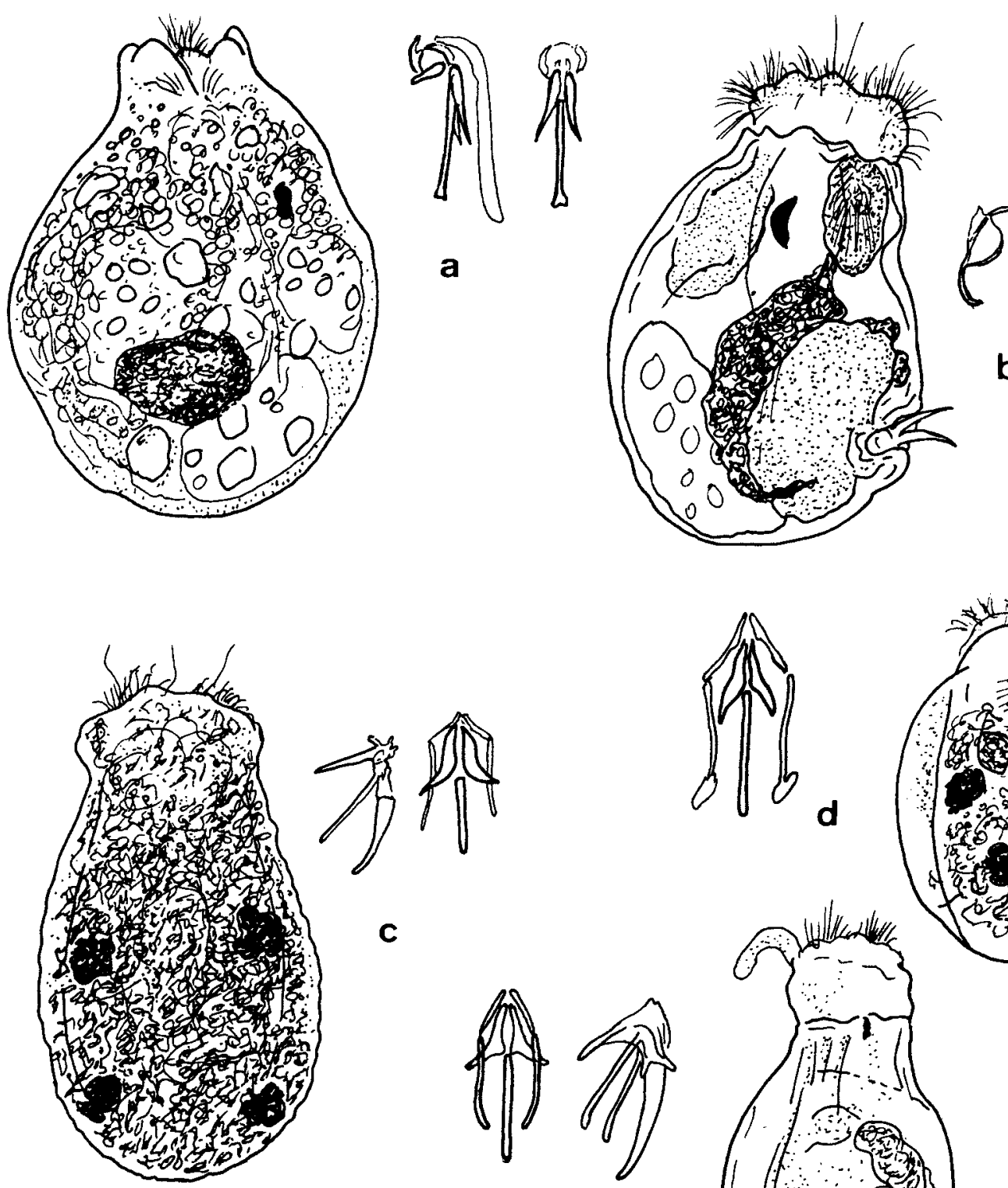

a
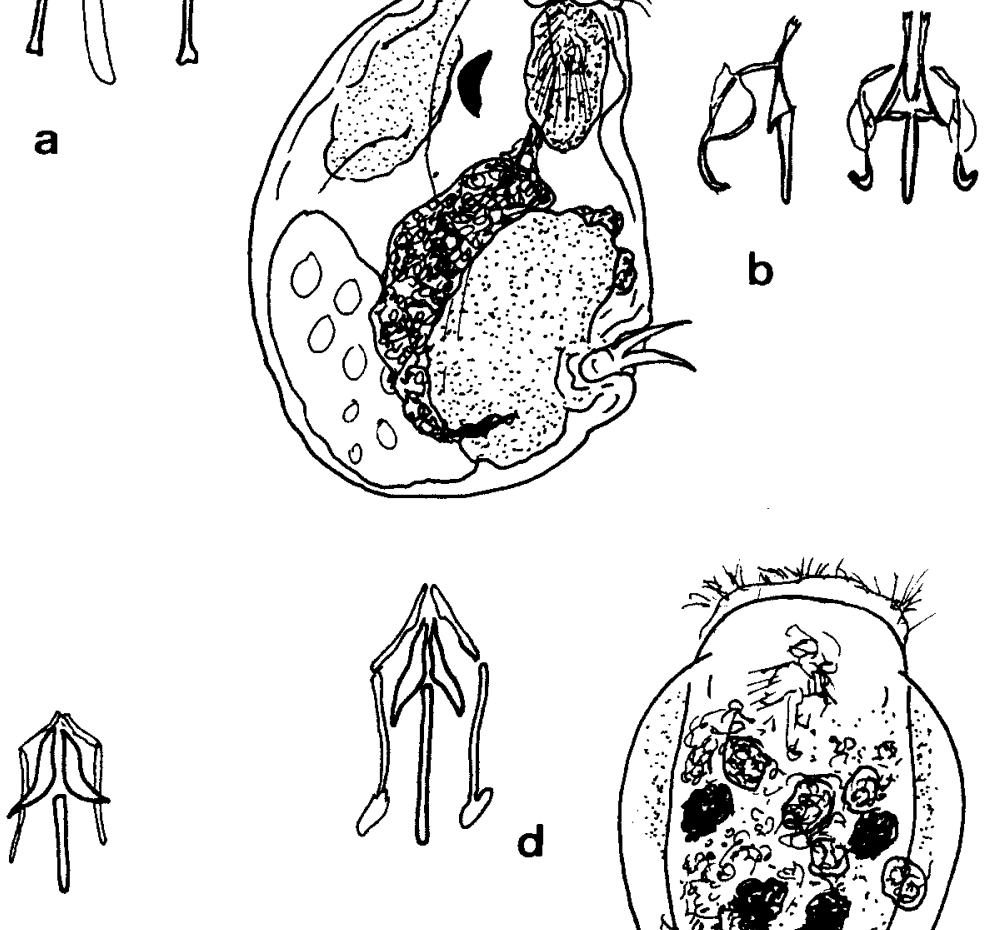

b

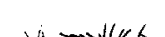


few records in other environments. However, one would expect a more widespread distribution.

Distribution in reservoirs. High occurrence in reservoirs, especially during the stratification period. It has been collected in 20 localities on which four samples were taken in winter.

\section{Genus Gastropus Perty}

Gastropus hyptopus (Ehrenberg, 1838) (Fig. 25 b; Fig. 26)

Notommata hyptopus Ehrenberg, 1838; Notops hyptopus Hudson \& Gosse, 1886; Gastropus hyptopus after Weber, 1898.
Ecology. Euplanktonic species, cold sternoterm. It feeds on Peridinium, but in warmer waters. It may feed on Sinura (Pourriot, 1965).

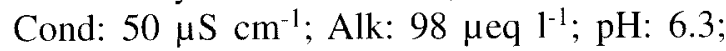
Temp: $9.5^{\circ} \mathrm{C}$

Morphological features of interest. Ventral foot bisegmented, ending with two acute toes. Sometimes difficult to distinguish in preserved material. Rami with anterior margin finely serrated. Vitellarium with 15 or more nuclei. Eyespot red and large.

Geographical distribution. Recorded in Europe, Asia and North-America, but probably cosmopolite. Rare, it is the first record for the rotifer Iberian fauna.

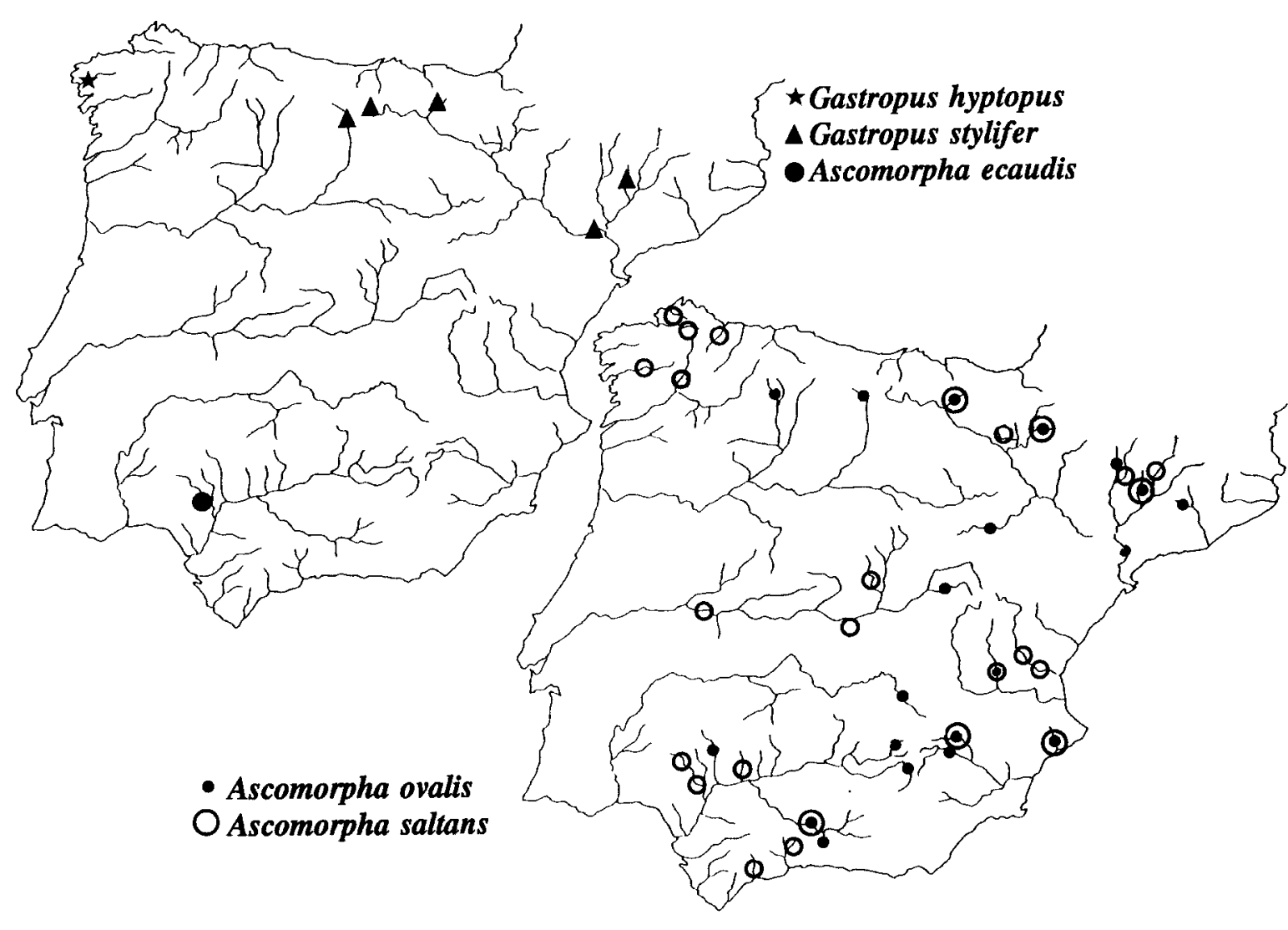

Figura 26 Distribution of some species of the family Gastropodidae in Spanish reservoirs (survey 1987/88). Distribucion de algunas especies de la familia Gastropodidae en los embalses españoles (estudio 87/88). 
Distribution in reservoirs. It has been found in winter samples from the reservoir Fervenza (15), the Westermost reservoir of those studied under a oceanic-marine climatic regime.

Gastropus stylifer (Imhof, 1891) (Fig. 25; Fig. 26)

Notops pigmaeus Calman, 1892; Hudsonella picta Zacharias, 1893; Sacculus orbicularis Kellicott, 1897.

Ecology. Planktonic species. Warm stenoterm. According to Braioni \& Gelmini (1983) this species is found in assembly with some colonial algae like Volvox and Dinobryon.

Cond: $197.2-1065 \mu \mathrm{S} \mathrm{cm}^{-1}$; Alk: 1210.3-3486 peq $\mathrm{I}^{-1}$; pH: 7.8-8.4; Temp: $10.6-21^{\circ} \mathrm{C}$

Morphological, features of interest. Ventral foot, protruding from the middle of the body; one triangular toe. Anterior margin of cuticle undulated (this character may be observed in contracted specimens). Vitellarium with 4-8 nuclei. Tube of prepharinx long and slender for sucking cell content of dinoflagellates.

Geographical distribution. Cosmopolite. In the Iberian peninsula it has only been found in reservoirs and in plankton samples from some Pyrenean ponds (unpublished data).

Distribution in reservoirs. It has been found distributed across the basin of the river Ebre: i.e Ebro, (6); Urrunaga, (4); Sta. Anna, (93); Mequinenza, (4). It the previous 1972/76 survey, it was collected in two Northern reservoirs, too.

Family SYNCHAETZDAE

Genus Pulyarthra Ehrenberg

Polyarthra dolichoptera (Idelson, 1925) (Fig. 27) Polyarthra platyptera var. dolichoptera Idelson, 1925; Polyarthra dolichoptera, after Carlin, 1943.

Ecology. Euplanktonic species; cold stenoterm, it tolerates low oxygen concentrations (Ruttner-Kolisko, 1974). Pourriot (1977) found that Polyarthra feeds on mainly cryptomanadaceae, chrysophyceae and central diatoms. Guiset $(1977 \mathrm{c})$ frequently found $P$. dolichoptera in the stomache contents of Asplanchnn and Ploesoma.

Cond: $27-3590 \mu \mathrm{S} \mathrm{cm}^{-1}$; Alk: 98-3871.7 peq $\mathrm{l}^{-1}$; pH: 6.33-9.18; Temp: 5.9-26.2 ${ }^{\circ} \mathrm{C}$

Morphologicalfeatures of interest. Polyarthra is a genus with controversial systematics. For instance, it is difficult to discriminate between $P$. dolichoptera and $P$. vulgaris only attending to morphology. Both species have ventral finlets, but with differences difficult to distinguish under an optic microscope (Fig. 27 h,i). Lateral blades of $P$. vulgaris are relatively broader and shorter than in $P$. dolichoptera, with differences in the serrated margins (Fig. $27 \mathrm{f}$ ). The body of $P$. dolichoptera is slightly smaller than that of $P$. vulgaris. Resting eggs are always double-shelled with folded skin within shells (Fig. 27). There are also differences between both species in mastax morphology, specially in details oframi (Koste, pers. com.). Guiset (1977b) distinguishes Polyarthra species by mesuring the dimensions of diagnostic traits: fulcrum length, resting egg and subitaneus egg diameters. Pejler (I 956) maintained introgression between both species to explain that some individuals can have intermediate characters between both species (Fig. 27 j,k).

Geographical distribution. Cosmopolite. It is widespread throughout the Iberian Peninsula, but it is likely that some records of $P$. dolichoptera in reality correspond to $P$. vulgaris and viceversa.

Distribution in reservoirs. It is very common and its occurrence is higher in winter than in summer. In some reservoirs it may be confined to the hypolimnion during the stratification period. In the $1987 / 88$ survey it was collected in 31 localities in winter and 14 in summer.

Polyarthra euryptera (Wierzejski, 1893) (Fig. 27; Fig. 28)

Polyarthra platyptera var euryptera Wierzejski, 1893.

Ecology. Euplanktonic species. Warm stenoterm. It prefers low alkalinity and eutrophic waters. Seasonal in Mediterranean latitudes, with maxima in summer. More abundant in the epilimnion during the stratification period. $P$. 
euryptera may be occasional prey for some predator rotifers such as Asplanchna girodi and Ploesoma hudsoni (Guiset, $1977 \mathrm{c}$ ).

Cond: $14-1175.6 \mu \mathrm{S} \mathrm{cm}^{-1}$; Alk: 58.2-3711.2 $\mu$ eq $\mathrm{I}^{-1}$; $\mathrm{pH}: 6.3-9.9$; Temp: $5.9-24.9$ "C

Morphologicalfeatures of interest. Large (150$170 \mathrm{pm})$. Vitellarium with 12 nuclei. Blades feather- like, broad (30-70 $\mu \mathrm{m})$, shorter than the body length, with a serrated margin and lateral nerves (Fig. 27 c). No ventral finlets. Resting eggs large $(85-110 \mu \mathrm{m})$, usually double-shelled, with folded skin between shells (Fig. 27 b).

Geographical distribution. Cosmopolite. In the Iberian Peninsula it has been found in various localities, mainly in reservoirs (Guiset, 1976).

Distribution in reservoirs. In the 1987/88 survey it was found in 13 reservoirs, nine in the stratification period and five in the mixing period. Guiset (1976), in the previous survey, found it in 40 localities, more often in reservoirs in the NW of Spain.

Polyarthra major (Burckhardt, 1900) (Fig. 27; Fig. 28)

Polyarthra platyptera var. major Burckhardt, 1900.

Ecology. Euplanktonic species, eurithermic in oligotrophic waters. In large waterbodies it often co-occurs with other species of the genus (Table $3)$. It has been found in the stomache content of Asplanchna girodi (Guiset 1977 c).

Cond: $14-1423.5 \mu \mathrm{S} \mathrm{cm}^{-1}$; Alk: 58.2-3711.2 $\mu$ eq $\mathrm{I}^{-1}$; pH: $6.3-10$; Temp: $6.45-25.5^{\circ} \mathrm{C}$

Morphological features of interest. No ventral finlets. Blades broad $(20-30 \mu \mathrm{m})$, feather-shaped (Fig. $27 \mathrm{~b}$ ); length of blades less than a body length. Body larger than $P$. vulgaris and $P$. dolichoptera. Vitellarium with 8 nuclei.

Geographical distribution. Cosmopolite. It has been found throughout the Iberian Peninsula.

Distribution in reservoirs. Relatively higher occurrence during the stratification period. Frequently in both summer and winter samples (i.e. found in 51 reservoirs in winter and in 46 reservoirs in summer).

Polyarthra remata (Skorikov, 1896)(Fig. 27; Fig. 28)
Polyarthra platyptera var. remata Skorikov, 1896.

Ecology. Planktonic species, occasionally found in littoral environments. Miracle (1976) found it in Lake Banyoles (NE Spain). Its abundance is strongly correlated with temperature. It prefers to alkaline waters. It feeds mainly on flagellates. It is often found associated to other species of Polyarthra. It is usually prey to Ploesoma hudsoni and species of the genus Asplanchna (Guiset, 1977 c).

Cond: $14.7-3590 \mu \mathrm{S} \mathrm{cm}^{-1}$; Alk: 74.7-3871.7 peq $\mathrm{I}^{-1}$; pH: $6.64-10$; Temp: $6.4-25.7^{\circ} \mathrm{C}$

Morphological features of interest. It is the smallest species of the genus $(<120 \mu \mathrm{m})$ found in reservoirs. Blades serrated, sword-shaped (Fig. $27 \mathrm{~g}$ ) and of equal length; longer than body. No ventral finlets. The number of nuclei and the absence of ventral finlets permit to distinguish this species from $P$. dolichoptera. Both species may be easily confused in preserved material.

Geographical distribution. Cosmopolite. Widespread throughout all the Iberian Peninsula.

Distribution in reservoirs. Frequent in stratification and mixing periods. It has been found in more than half of reservoirs (Fig. 28).

\section{Polyarthra vulgaris (Carlin, 1943) (Fig. 27)}

Polyarthra trigla Ehrenberg, 1834; Polyarthra trigla vulgaris Pourriot, 1965.

Ecology. Euplanktonic species. Euritherm and perennial. It prefers superficial waters and very oxygenated environments (it is rarely found in hypolimnion). According to Pourriot (1977) it feeds on cryptomonadaceae, chrysophyceae and central diatoms. Guiset $(1977 \mathrm{c})$ found P. vulgaris was a frequent prey of Asplanchna and Ploesoma.

Cond: $14-3720 \mu \mathrm{S} \mathrm{cm}{ }^{-1}$; Alk: 68.3-4681.7 peq $\mathrm{l}^{-1}$; pH: $6.6-9.9$; Temp: $5.9-26.7^{\circ} \mathrm{C}$

Morphologicalfeatures of interest. Ventral finlets setiform and smooth (Fig. $27 \mathrm{~h}$ ). Vitellarium with eight nuclei. Blades as long as body (8-20 $\mu \mathrm{m}$ broad), feather-like and slightly serrated (Fig. $27 \mathrm{e}, \mathrm{j}, \mathrm{k}$ ). Form and length of blades are not good characters to separate this species from $P$. dolichoptera. Both species have highly variable 

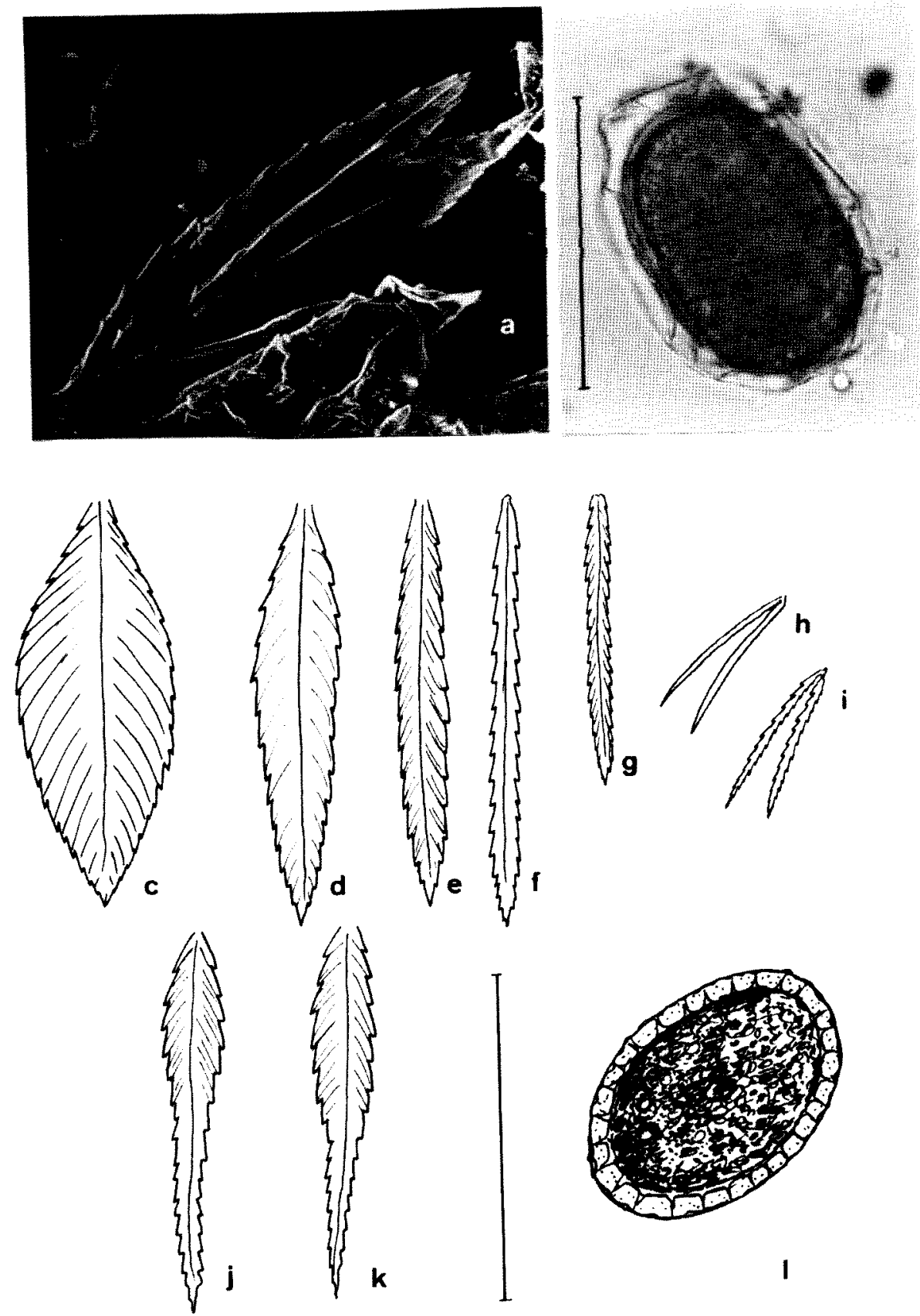

Figura 27. Structures of somes species of the genus Polyarthra found in Spanish reservoirs during the $87 / 88$ survey. a, blades from $P$. major, from Riudecanyes; b, resting egg from $P$. euryptera, from La Tranquera; c, blades from $P$. euryptera; d, blades from P. major; e, blades from $P$. vulgaris; f, blades from $P$. dolichoptera; $\mathrm{g}$, blades from P. remata; $\mathrm{h}$, i ventral finlets, $\mathrm{h}, P$. vulgaris, $\mathrm{i}, P$. dolichoptera; $\mathrm{j}, \mathrm{k}$, finlets from intermeste medial forms $P$. vulgaris/dolichoptera; 1, resting egg from P. dollh) a ándice de P. major, de Riudecanyes; $b$, huevo durable de P. eurypte-

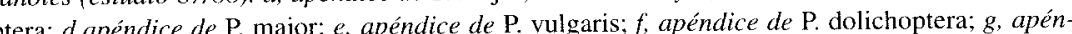
ra, de La Tranquera; $c$, apéndice de P. euryptera; d,apéndice de P. major; $e$; ap dice de $\mathrm{P}$ remata; $h$, iapéndices ventrales, $h$. P. vulgaris, $i$, P. dolichoptera; $j, k$, apéndices de formas intermedias $\mathrm{P}$. vulgaris/dolichoptera; $l$, huevo durable de P. dolichoptera. Escala $100 \mu \mathrm{m}$. 


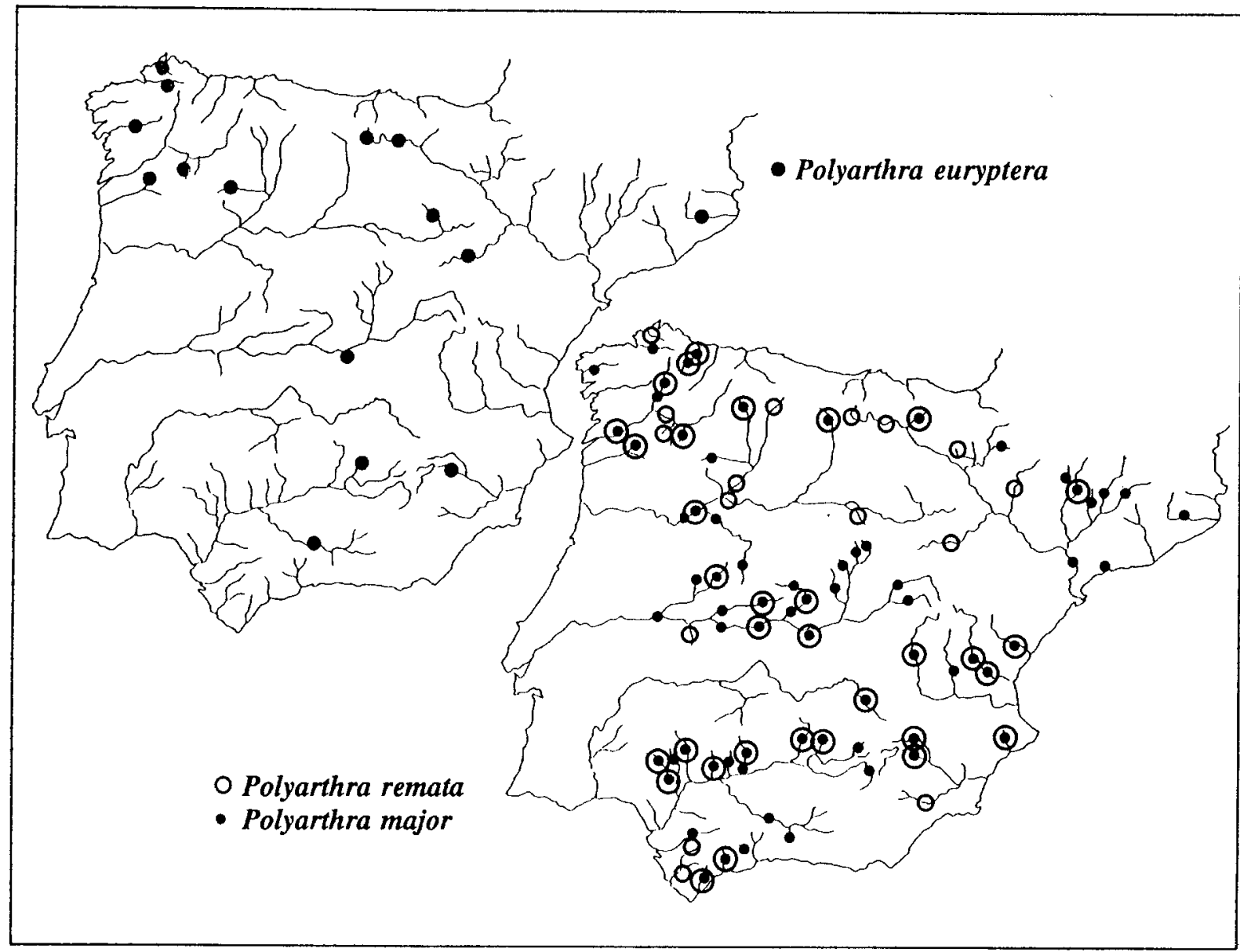

Figure 28. Distribution map for some species of the genus Polyarthra (survey 87/88). Distribución de algunas especies del género Polyarthra (estudio $87 / 88$ ).

morphologic characters. It is also possible the hybridization between these two species, (Pejler, 1956).

Geographical distribution. Cosmopolite. It is the species of this genus that is more recorded in Spain. However, as has been pointed out, it is possible some of these records may have confused both species.

Distribution in reservoirs. Very frequent and abundant. In the 1987/88 survey it was found in 75 reservoirs in summer and in 70 in winter.
Genus Ploesoma (Bipalpus) Herrick, 1885

Ploesoma hudsoni (Imhof, 1891) ( Fig. 31)

Gastropus hudsoni Imhof, 1891; Gastroschiza flexilis Jägerskiold, 1892; Bipalpus vesiculosus Wierziejski \& Zacharias, 1893; Dictyonema hypopus Lauterborn, 1893; Ploesoma hudsoni after Jennings, 1894.

Ecology. Euplanktonic. Seasonal, in summer it is found in lakes and in reservoirs of low alkalinity. Rare in ponds, it prefers slightly acid waters, with low mineralization. Omnivore, but considered as carnivore. It feeds on other rotifer species 


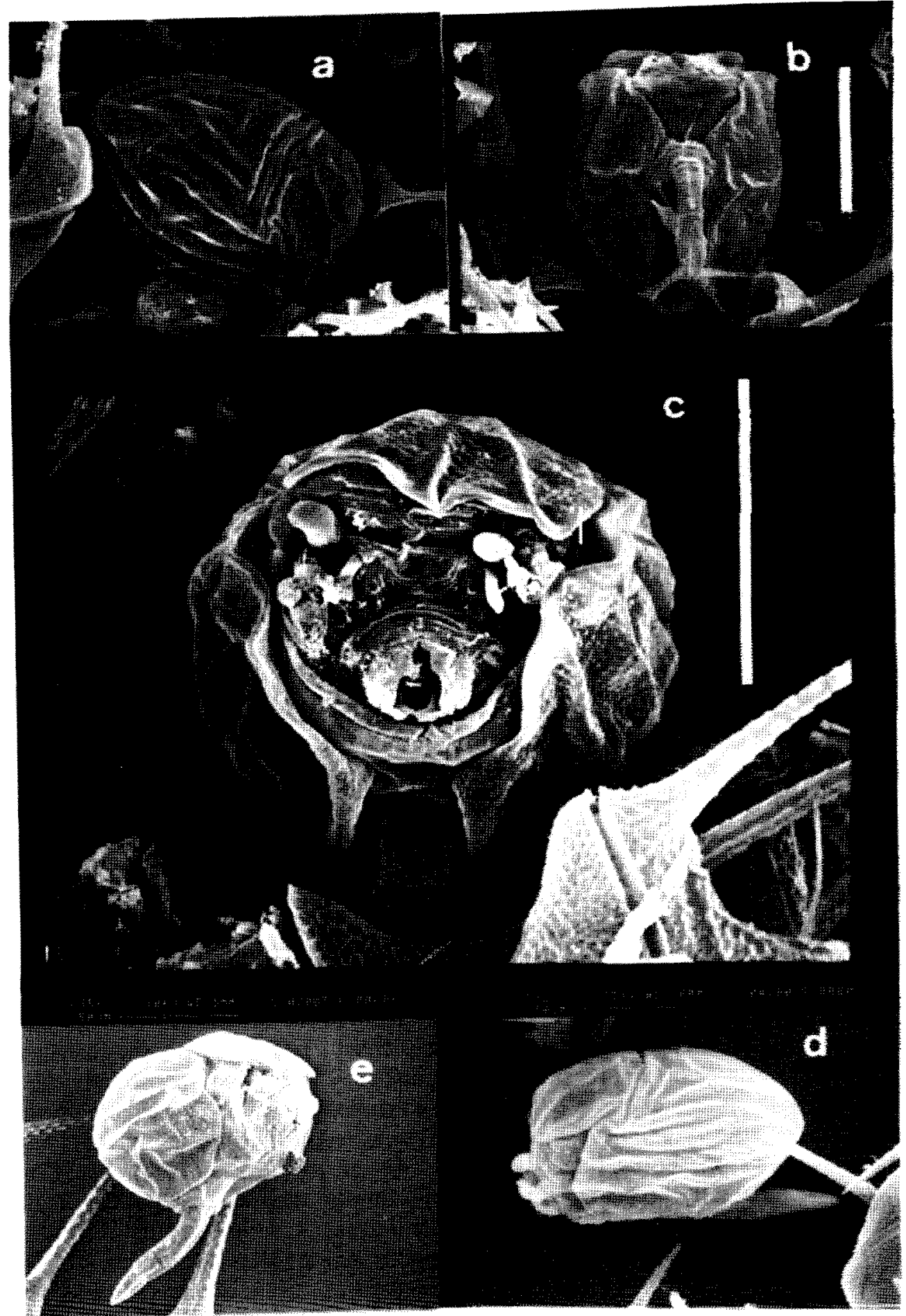

Figure 29. SEM micrographs of Ploesoma truncatum (Levander) collected in El Grado. a, dorsal view; b, ventral view; c, frontal view; c, d, lateral views. Scale bar 50 um. Microfotografías MEB de Ploesoma truncatum (Levander) muestreado en El Grado, a, vista dorsal; b, vista ventral; $c$, vista frontal; $c, d$, vista lateral. Escala lineal $50 \mu \mathrm{m}$. 
and various algae. Guiset (1977c), studied the stomach content of some populations of $P$. hudsoni, he found diatoms, dinoflagellates, volvocales, chlorococales, desmidiaceae and rotifers (species of the genus Polyarthra, Synchaeta, Keratella and Trichocerca. As well as Asplanchna priodonta, another predator rotifer).

Cond: $14-293 \mu \mathrm{S} \mathrm{cm}^{-1}$; Alk: $58.2-2470 \mu \mathrm{eq} \mathrm{I}^{-1}$; pH: 6.3-9.67; Temp: $7.8-23.9^{\circ} \mathrm{C}$

Morphological features of interest. Large (300 to $600 \mathrm{pm}$ ). Lorica presents blisters or vacuoli ventraly situated, giving at the specie a "bubbly" appearance. No ventral furrow. Foot long, annular, ended with two large toes. Head with two finger-like palps. Large virgate trophy, that may be partially projected to catch prey.

Geographical distribution. Holartic (Koste, 1978). In the Iberian Peninsula it has been identified mostly in north-western waterbodies, but also in other northern localities (Margalef, 1973; Miracle, 1978; Telleria, 1981). It is also frequent in Pyrenean lakes (unpublished data).

Distribution in reservoirs. Mostly found in summer, in reservoirs from the north-west of Spain. Frequent in reservoirs of the river Miño basin. It has increased its area of distribution with respect to the previous study of the reservoirs (Fig. 31).

Ploesoma truncatum (Levander, 1894) (Fig. 4. 28; Fig. 31)

Gastroschiza truncata Levander, 1894; Ploesoma truncatum after Weber, 1898.

Ecology. Planktonic species. It may also be found in the littoral area, too. Warm stenoterm. It feeds on algae and other rotifers (Koste, 1982).

Cond: $291 \mu \mathrm{S} \mathrm{cm}^{-1}$; Alk: $2206 \mu \mathrm{eq} \mathrm{^{-1 }}$; pH: 8.4; Temp: $18.4^{\circ} \mathrm{C}$

Morphological features of interest. Smaller than $P$. hudsoni $(150-300 \mu \mathrm{m})$. Lorica ringed with ventral furrow. Head-shield present, without teeth. Eye red. Head with two finger-like palps. Geographical distribution. Probably cosmopolite. Rare. In Spain it had previously been collected in some reservoirs and in the Lakes of Ruidera (Armengol et al., 1975)

Distribution in reservoirs. In the previous study of the Spanish reservoirs it was found in
Peiiarroya (55), in the basin of the river Guadiana. it was then suggested that the species had probably colonized the reservoir from the Lakes of Ruidera (Guiset, 1976).In the 1987/88 survey it was found in El Grado (81), in summer and relatively far away from Peiiarroya, suggesting that the species had colonized from Pyrenean lakes (in these, $P$. truncatum has not been recorded yet, but may be highly seasonal and therefore difficult to observe.

Genus Synchaeta Ehrenberg, 1832.

Synchaeta kitina (Rousselet, 1902) (Fig. 30 c,d; Fig. 31)

Synchaeta tremula var. kitina Rousselet, 1902; Synchaeta kitina Stemberger

Ecology. Euplanktonic species, it prefers slightly alkaline waters. High tolerance to salinity. During stratification it inhabits the epilimnion and its abundance is reduced with depth (Guiset, pers. com.). S. kitina may carry subitaneous eggs during a short time, but also eggs attached to planktonic diatoms have been also observed.

Cond: $20-1126 \mu \mathrm{S} \mathrm{cm}{ }^{-1}$; Alk: 146.5-3468 peq $\mathrm{l}^{-1}$; pH: 6.2-8.9; Temp: 7.3-24 ${ }^{\circ} \mathrm{C}$

Morphologicalfeatures of interest. Cone-shaped body (not contracted specimens). Head more or less flat. Externally very similar to $S$. tremula and $S$. oblonga. Size differences may be found (e.g. S. kiti$n a$ is smaller), in the situation of the lateral antennae (e.g. in the case of S. kitina these are located on the base of the foot). All this characters, however, are difficult to see occulted in material that has been preserved. The main diagnostic characters are morphological (Fig. $30 \mathrm{c}$ ), particularly the shape and morphology of teeth in uncus (Stemberguer, 1979). Resting eggs presents small spines.

Geographical distribution. Cosmopolite. Uniformly distributed throughout the Iberian Peninsula. S. kitina occurs mainly in coastal ponds and lagoons (Menéndez \& Comín, 1986; Forés et al., 1986; Oltra \& Miracle, 1984; Pretus et al., 1992). It is difficult to distinguish from other species of its genus (e.g. S. littoralis, Rousselet), which can be found the same environments. 


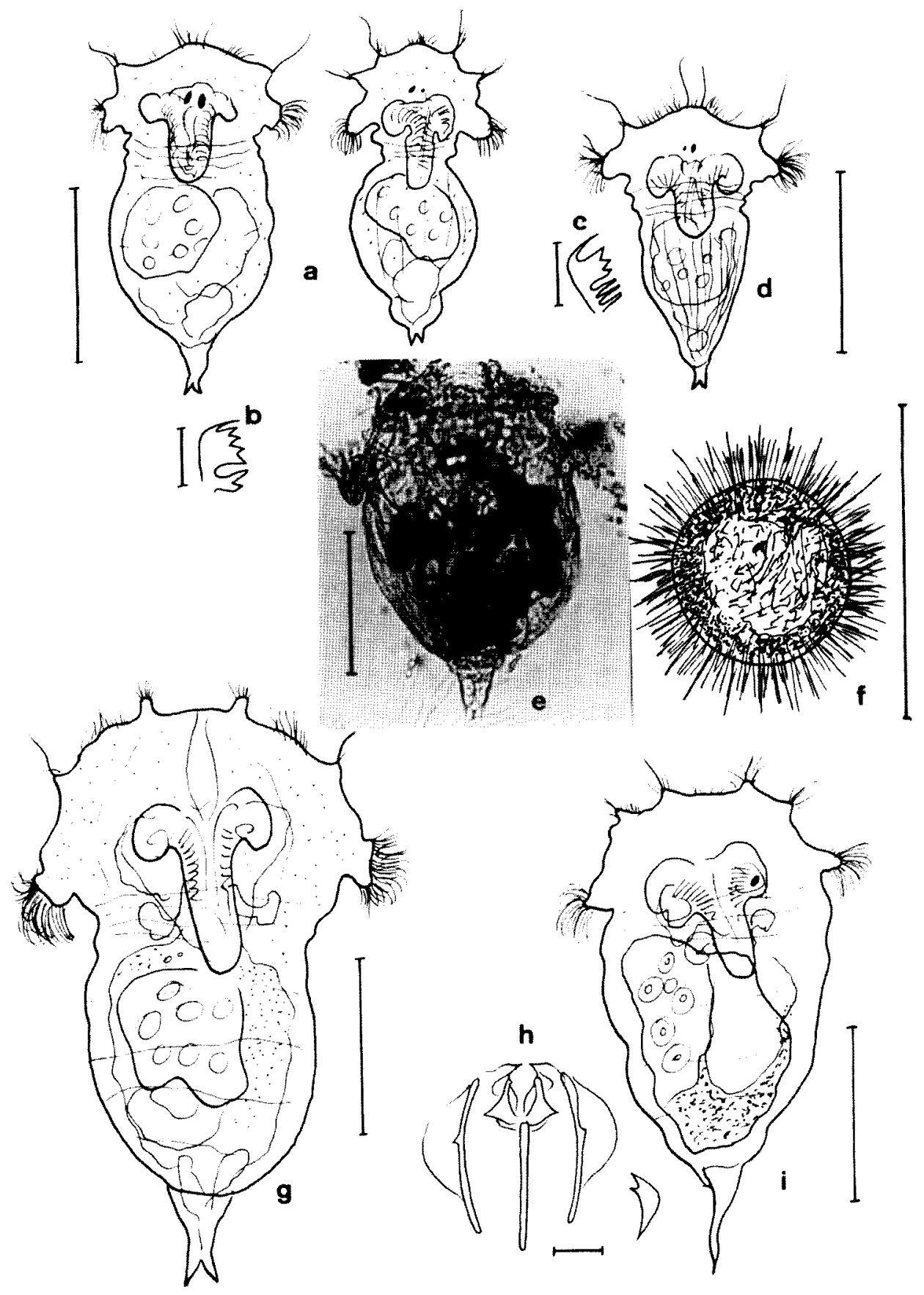

Figure 30. Species of the genus Synchaeta found in Spanish reservoirs during the $87 / 88$ survey. Scale bars are $100 \mu \mathrm{m}$ long except for photographs of mastax which are $20 \mu \mathrm{m}$ long. a, b, S. oblonga. (left) from Boadella, (right) from Aldeávila, b, detail of unci; c, d, S. kitina, from tographs of mastax which are $20 \mu \mathrm{m}$ long. a, b, S. oblonga. (eft) Boadella, c detail of unci; e, g, S. pectinata, e, infected by Bertramia asperosfora from Forcadas, g, from iñoles (estudio 87/88). Escala: 100 Boadella, h, mastax and detail from unci. Especies del género Synchaeta muestreadas en los embalses españoles (estudio $87, c$, Es $\mathrm{S}$. kitina, de $\mu m$ excepto para mastax: $20 \mu m . a, b$, S. oblonga, (izquierda) de Boadella, (derecha) de Aldeávila, $b$, detalle del uncus; $c, d, \mathrm{~S}$. kitina, de
Boadella, $c$ detalle del uncus; $e, g$, S. pectinata, $e$, infectado por Bertramia asperosfora de Forcadas, $g$, de Boadella; $h, i, \mathrm{~S}$. stylata, de Boadella, $h$, mastax y detalle del uncus. 
Distribution in reservoirs. In the 1987/88 study this species was not as abundant as other species of the genus. It was found in six reservoirs in summer and 11 in winter. In the 1972/76 study of the reservoirs its recorded occurrence was higher (37 localities).

Synchaeta oblonga (Ehrenberg, 1832) (Fig. $30 \mathrm{a}, \mathrm{b})$

Synchaeta neglecta Zacharias, 1901; Synchaeta pectinata f. minor Wesenberg-Lund, 1930.

Ecology. Euplanktonic species. Euritherm, but its abundance is higher in winter. More frequent in alkaline and eutrophic waters. High tolerance to salinity. It feeds on cryptomonadaceae and central diatoms (Pourriot, 1970). It often carries its eggs during a short time. $S$. oblonga is a common prey of Asplanchna (Guiset, 1977c).

Cond: $35-5326.6 \mu \mathrm{S} \mathrm{cm} \mathrm{cm}^{-1}$; Alk: 58.2-4681.7 peq $\mathrm{I}^{-1}$; pH: 6.3-8.8; Temp: $5.9-22.8^{\circ} \mathrm{C}$

Morphologicalfeatures of interest. Body wellshaped $(<250 \mu \mathrm{m})$, head convex. No apical tentacles and double cerebral eye. Smaller than $S$. pectinata. However, in fixed specimens size is not sufficient to distinguish them and it is often necessary to examine mastax morphology. Specifically, size of the trophy and the unc comblike ends (Fig. $30 \mathrm{~b}$ ), are the characters to look for. Confusion is common with S. kitina and $S$. tremula, which may coexist. Carlin (1943) and Pejler (1957) suggested that S. oblonga, S. tremula and S. lakowitziana, were considered to be the same species, but later Pejler (1962) recognized them as three separate species. RuttnerKolisko (1974) grouped theses three taxa (Synchaeta g. tremula-oblonga). Perhaps a revision of the genus is necessary, for example, the morphology of the mastax under SEM as a diagnostic criterion.

Geographical distribution. Cosmopolite. In the Iberian Peninsula it has been recorded mostly in reservoirs.

Distribution in reservoirs. It was one of the most common rotifers in the 1987/88 survey mainly during the mixing period (58 reservoirs). In the $1972 / 76$ study it was found in only 21 localities.
Synchaeta pectinata (Ehrenberg, 1832) (Fig. $30 \mathrm{e}, \mathrm{g})$

Synchaeta inordax Gosse, 1851; Hydatina pectinata Acloque 1899.

Ecology. Euplanktonic species. Eurioic, perennial, it presents its maxima at low temperature. It may inhabit both small and large waterbodies. Phytophagus, it feeds on cryptomonadaceae, chrysophyceae, and central diatoms (Pourriot, 1970). It is frequently found infected by the microsporid Plistophora (Bertramia)asperospo$\mathrm{ra}$ (Fig. $30 \mathrm{e}$ ).

Cond: $14-1522.6 \mu \mathrm{S} \mathrm{cm}{ }^{-1}$; Alk: 58.2-4681.7 peq $\mathrm{l}^{-1}$; pH: 6.3-9.3; Temp: $5.9-25.5^{\circ} \mathrm{C}$

Morphological features of interest. It presents two bristle-bearing apical tentacles. Length $<510$ $\mathrm{pm}$. Single eye. Teeth with pointed tips. Asexual eggs with oil drops and gelatinous case; resting eggs with blisters or short spines. Short foot, of conical shape, with two equal and relatively short toes. Vitellarium with eight large nuclei. RuttnerKolisko (1974) defined the stylata-pectinata group, constituted by a series of closely-related and very similar species.

Geographical distribution. Cosmopolite. S. pectinata is a widespread species in Spain.

Distribution in reservoirs. In the 1987/88 survey it was found in 30 reservoirs in summer and in 59 in winter. No pattern of distribution was apparent.

Synchaeta stylata (Wierzejski, 1893) (Fig. 30 f,h,i; Fig. 31)

Synchaeta wesenberg-lundi Pejler, 1957.

Ecology. Euplanktonic species, inhabitant of large waterbodies. Warm stenoterm; markedly seasonal (summer).

Cond: 47.3-1423.5 $\mu \mathrm{S} \mathrm{cm}^{-1}$; Alk: 225-3562.5 peq $\mathrm{I}^{-1}$; pH: 7.1-9.9; Temp: $8.7-25.5^{\circ} \mathrm{C}$

Morphological features of interest. Body bellshaped, or as a plump to slender cone. Head convex, no apical tentacles. Very similar to Synchaeta pectinata, but terminated with a slender foot with a long toe. Subitaneous eggs with oil drops and long thin bristles (Fig. $30 \mathrm{f}$ ). Teeth with pointed tips (Fig. $30 \mathrm{~h}$ ).

Geographical distribution. Cosmopolite. It presents a northern distribution in Spain, but it 


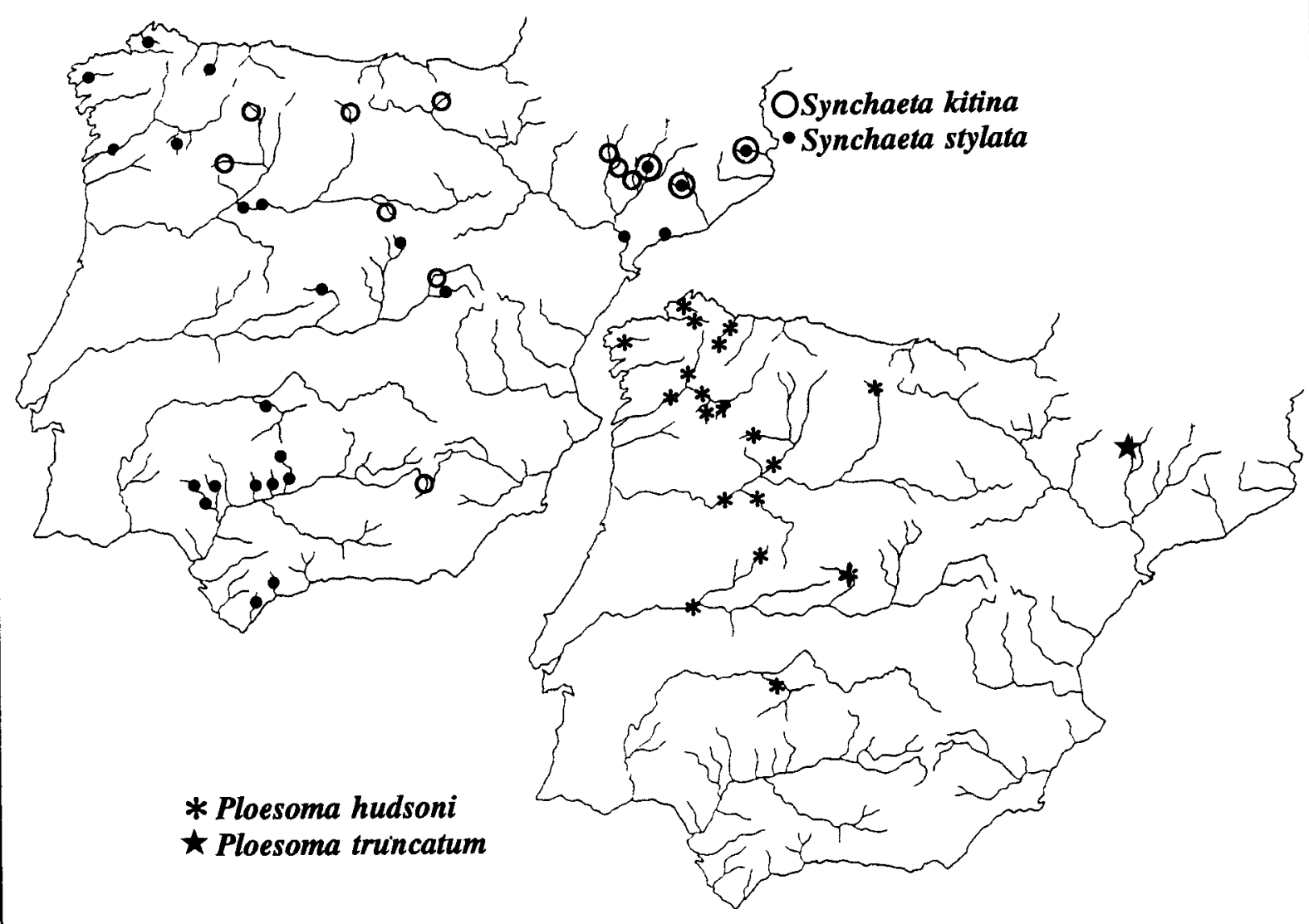

Figure 31. Distribution of some species of the genera Synchaeta and Ploesoma in Spanish reservoirs found during the 87/88 survey. Distribución de algunas especies del género Synchaeta and Ploesoma en los embalses españoles (estudio87/88).

has been found in the Delta de l'Ebre (Forés et al. 1986).

Distribution in reservoirs. It has extended its distribution. In the 1987/88 survey it was collected in 20 reservoirs in the stratification period and two during the mixing period. Previously, it had only been found in six reservoirs.

Family ASPLANCHNIDAE

Genus Asplanchna Gosse

Asplanchna brightwelli Gosse, 1850 (Fig. 32 d; Fig. 3.32)
Asplanchna bowesii Gosse, 1850; Ascomorpha anglica Perty, 1852; Notommata anglica Leydig, 1854; Apus anglica Schoch, 1886; Apus ceylonica Daday, 1898.

Ecology. Euplanktonic species. It feeds mainly on rotifers, but its diet is also composed by crustacean nauplii and a variety of algae. According to Salt (1977), A. brightwelli and A. girodi are food competitors. Guiset $(1977 \mathrm{c})$ found that $A$. brightwelli feeds positively selecting specimens of Synchaeta, Polyarthra vulgaris/dolichoptera, $P$. remata, Pompholyx sulcata and also Filinia and Trichocerca individuals, but shows negative 


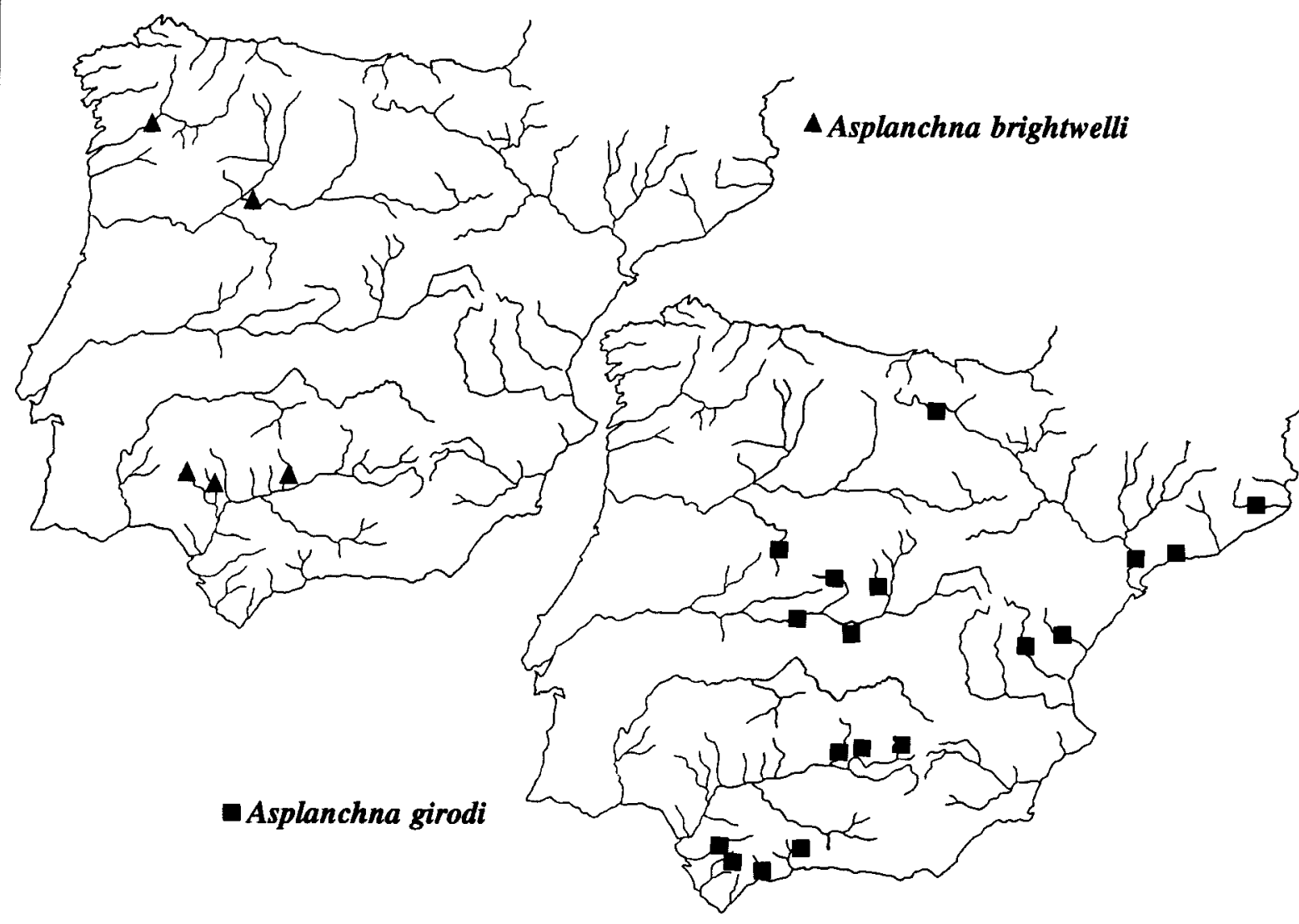

Figura 32. Distribution of some species of the genus Asplanchna in Spanish reservoirs (survey 1987/88). Distribución de algunas especies del género Asplanchna en los embalses españoles (estudio 87/88).

selection for specimens of Brachionus, Keratella cochlearis, large Polyarthra and individuals of its own species. The same author, however, found that rotifer diversity in the stomache content of $A$. brightwelli was not significantly different from the rotifer diversity of the reservoir. The presence of polymorphic individuals or a diet rich in tocopherol in diet induce mixis in cruciform females (Gilbert, 1967).

Cond: 79-541 $\mu \mathrm{S} \mathrm{cm} \mathrm{cm}^{-1}$; Alk: 1297.2-3038 $\mu$ eq $1^{-1}$; pH: 8.1-8.8; Temp: $17.5-26.2{ }^{\circ} \mathrm{C}$

Morphological features of interest. Sackshaped body. It is the largest planktonic rotifer found in reservoirs $(500-1500 \mu \mathrm{m})$. It presents plasticity in shape, mainly as a consequence of variations in food supply (Gilbert \& Birky, 1971). Vitellarium lobed, with 32 nuclei, horseshoe-like. Tooth on inner margin of ramus well developed. Apophysis present (Fig. 33). Very similar and sometimes confused with $A$. sieboldi. Differences should be found in the number of flame bulbs of protonephridia (10-20: A. brightwelli; 40-100: A. sieboldi) and the number of nuclei of the vitellarium (16 in $A$. sieboldi).

Geographical distribution. Cosmopolite. In the Iberian Peninsula it has been found in the Guadalquivir estuary (Guisande \& Toja, 1988) and in some reservoirs. 
Distribution in reservoirs. In the $1987 / 88$ survey it was found in summer samples from five reservoirs. In the previous study it was collected in seven localities, six of them during summer.

Asplanchna girodi (De Guerne, 1888) (Fig.32 f; Fig. 33)

Ecology. Planktonic species, occasionally littoral. It prefers eutrophic and slightly alkaline waters. Guiset (1977c) found A. girodi feeds positively selecting species of Synchaeta, small Trichocerca and Polyarthra vulgaris/dolichoptera. Recently, Pompholyx sulcata and Keratella cochlearis $f$. tecta have also been found in its stomach content. A. girodi probably is in competition with the predator rotifer Ploesoma hudsoni.

Cond: $31.5-3720 \mu \mathrm{S} \mathrm{cm}^{-1}$; Alk: 58-3882 $\mu \mathrm{eq} \mathrm{I}^{-1}$; pH: 6.3-9.9; Temp: 7.7-26.2 ${ }^{\circ} \mathrm{C}$

Morphological features of interest. Protonephridia with 16 flame bulbs, 50 nuclei in vitellarium. The morphology of the mastax is the main distinguishable feature of this species (Fig. $32 \mathrm{f}$ ).

Geographical distribution. Cosmopolite. It is widespread in the Iberian Peninsula.

Distribution in reservoirs. It has been found in 21 samples, from 18 reservoirs. A. girodi is more frequent in summer.

Asplanchna priodonta Gosse, 1850(Fig. 33 a-c, e)

Asplanchna krameri De Guerne, 1888; Asplanchna priodonta pelagica Zacharias, 1892.

Ecology. Euplanktonic species. Euriterm and perennial. Poliphagus, it feeds preferentially on plankton diatoms, dinoflagellates and rotifers. Its diet is less carnivorous than that of $A$. girodi (Guiset, 1977; Gilbert, 1980).

Cond: $19.6-1385 \mu \mathrm{S} \mathrm{cm}^{-1}$; Alk: $98-4681$ peq $\mathrm{l}^{-1}$; pH: 6.3-9.67; Temp: $5.9-25.9^{\circ} \mathrm{C}$

Morphologicalfeatures of interest. Easily distinguishable from other species of its genus looking at the morphology of the mastax (Fig. 32 e): p.e. robust, acute uncus, rami serrated on inner edges, broad and free ends. Protonephridia are compact, with 4 flame bulbs each.

Geographical distribution. Cosmopolite. It is the most common species of the genus Asplanchna in the Iberian Peninsula. It is also common in Pyrenean lakes.

Distribution in reservoirs. Very common; it has been found in 123 samples. In both studies it occurred in approximately the same frequency in the stratification and the mixing periods.

\section{Family TESTUDINELLIDAE}

Genus Pompholyx Gosse

Pompholyx sulcata (Hudson, 1885)(Fig. 34 c-g)

Ecology. Euplanktonic species. Euriterm in fresh and brackish waters. Feeds on detritus and bacteria (Pourriot, 1977). It prefers eutrophic environments. Asexual eggs attached to lorica by a filiform structure (Fig. 34 c). It is predated by Asplanchna girodi (Guiset, 1977c) and may be parasitized by the sporozoa Plistophora asperospora.

Cond: $45-1126.3 \mu \mathrm{S} \mathrm{cm} \mathrm{cm}^{-1}$; Alk: 225-3882 $\mu$ eq $\mathrm{I}^{-1}$; $\mathrm{pH}$ : 7-10.2; Temp: $6.4-26.2^{\circ} \mathrm{C}$

Morphological features of interest. Lorica not flattened dorso-ventrally. It presents four lobules, two lateral, one ventral and one dorsal (cross section as in Fig. 33, d). This is the main difference with the similar species $P$. triloba. It presents cyclomorphosis, i.e. in winter it is slightly larger, with a longer lorica, than in summer (Fig 34 e,f,g). Cloacal opening, where asexual eggs are attached is slightly curved ventrally. Eggs are round, up to $75 \mu \mathrm{m}$ in size and sometimes carried on a retractile thread from a secretory gland. Resting eggs are dark, smooth and double-shelled.

Geographical distribution. Cosmopolite. It has been found in some localities in Spain. Its occurrence and abundance in reservoirs is high.

Distribution in reservoirs. It has been found in 65 reservoirs. More frequent and abundant during the stratification period. P. sulcata has increased its distribution area in relation to that delimitated by the $1972 / 76$ survey. In this latter survey it was found in 68 samples from 39 localities.

Genus Testudinella Bory de St. Vincent

Testudinella emarginula (Stenroos, 1898) (Fig. 34 b) 

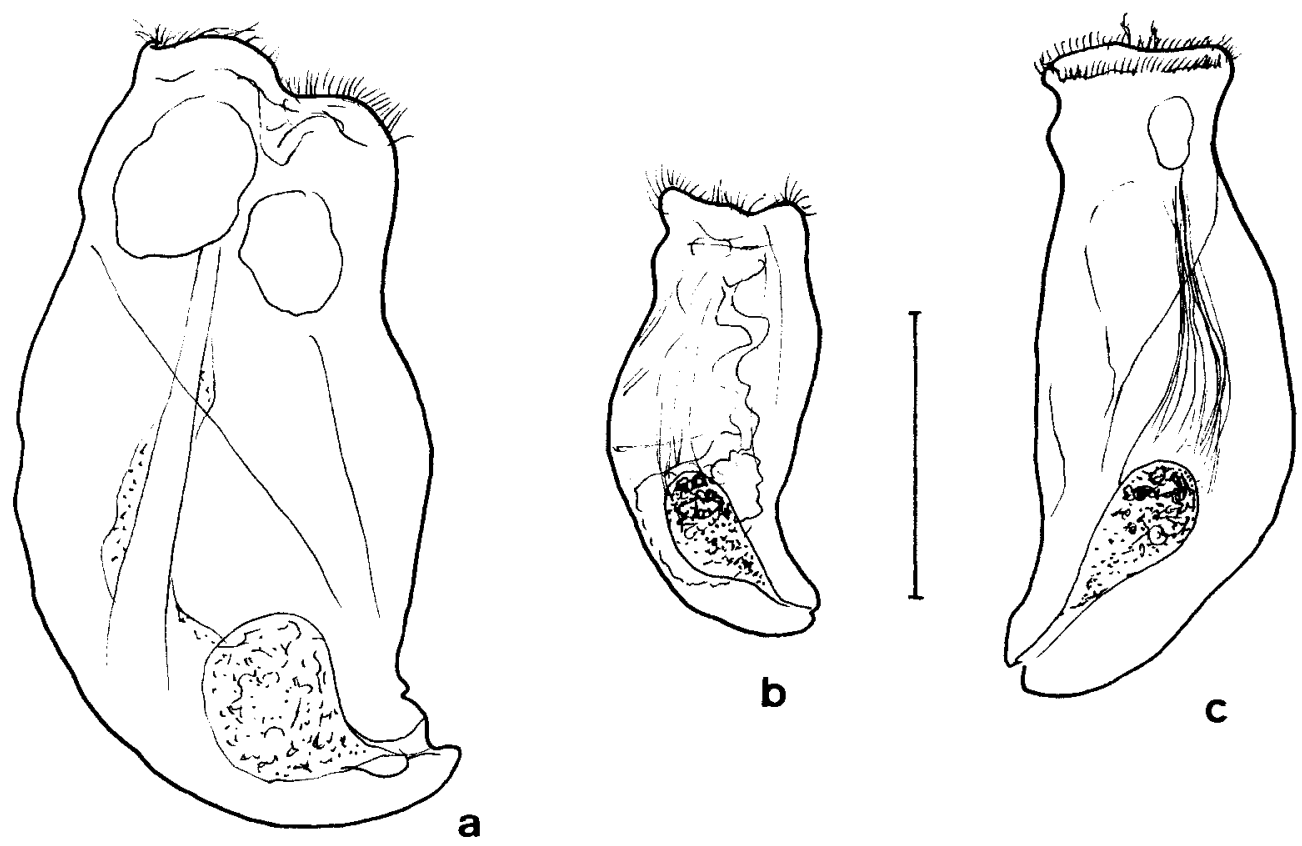

a
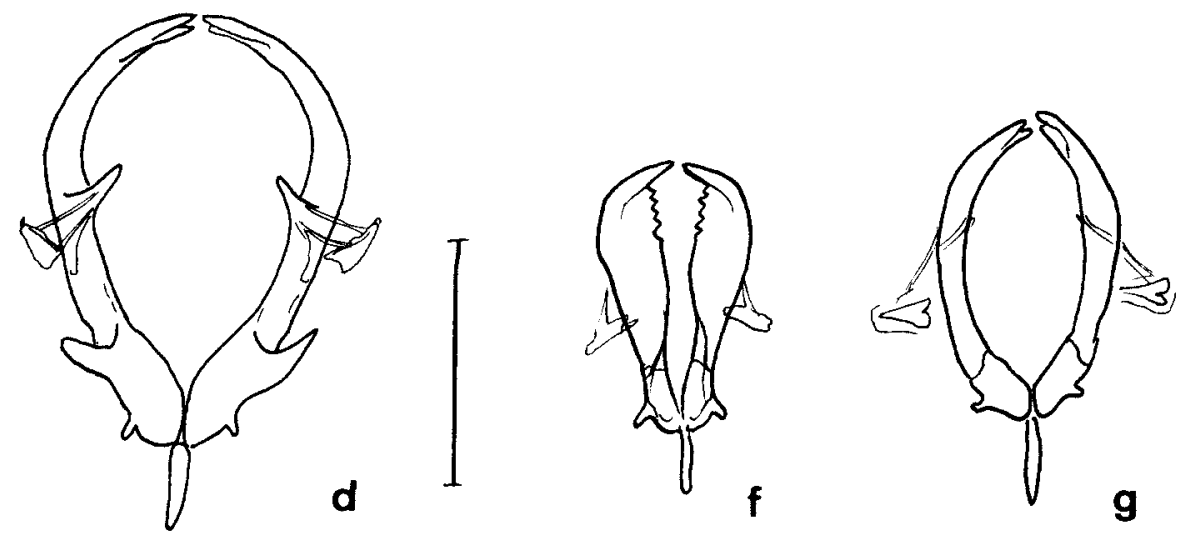

Figura 33. a-c, Some males of Asplanchna pridonta from: a, Linares del Arroyo, b, Guadalteba and c, Riudecanyes. Scale bar is $100 \mu \mathrm{m}$ long d-f, Mastax of some species of the genus Asplanchna. d A. brightwelli from Velle, e, A. priodonta from San Juan, e, A. girodi, from Riudecanyes. Scale bar is 50 long $\mu \mathrm{m}$. a-c, algunos machos de Asplanchna pridonta de: a, Linares del Arroyo, $b$, Guadalteba, $c$, Riudecanyes. Escala $100 \mu m$. d-f. Mastax de algunas especies del género Asplanchna. d A. brightwelli de Velle, e, A. priodonta de San Juan, e, A. girodi, de Riudecanyes. Escala: $50 \mu \mathrm{m}$. 


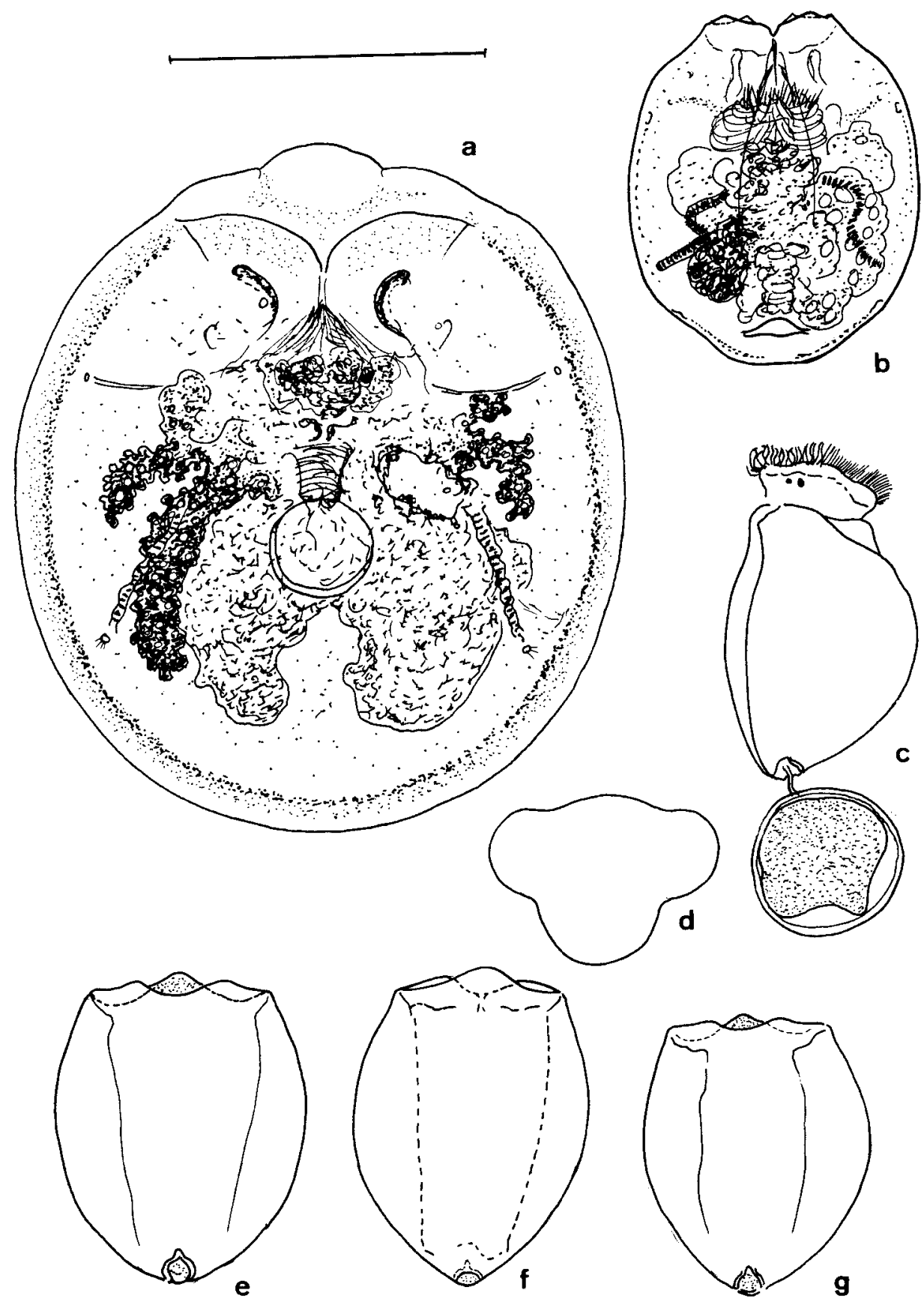

Figura 34. Some Testudinellidae found in Spanish reservoirs during the $87 / 88$ survey. Scale bar is $100 \mu \mathrm{m}$. long. a, Testudinella patina dendradena from Fervenza; b, Testudinella emarginula from As Conxas; c, d, e, f, g, Pompholyx sulcata. c, with egg from San Juan, d, cross section of the same specimen, e, ventral view (winter form) from Valdecañas, f, dorsal view (winter form) from La Minilla, g, ventral view (summer form) from San Juan. Algunas Testudinellidae de los embalses españoles (estudio 87/88). Escala: 100 rm.a, Testudinella patina dendradena de Fervenza; $b$. Testudinella emarginula de As Conxas; $c, d, e, f, g$. Pompholyx sulcata. $c$, con huevo de San Juan, $d$, vista transversal del mismo especimen, $e$, vista ventral (forma de invierno) de Valdecañas, $f$, vista dorsal (forma de invierno) de La Minilla, $g$, vista ventral (forma de verano) de San Juan. 
Pterodina emarginula Stenroos, 1898; Pterodina incisa Harring, 1913; Pterodina emarginula von Hofsten, 1909; Testudinella emarginula after Carlin, 1939; Testudinella incisa var. emarginula, Koste, 1978.

Ecology. Periphytic species; occasionally it may be found in plankton. Cold stenoterm, it tolerates a wide range of alkalinity, but may be collected in slightly acid waters. Its autoecology is not well-known.

Cond: 51.5- $262 \mu \mathrm{S} \mathrm{cm}{ }^{-1}$; Alk: 171- 2003 peq $\mathrm{I}^{-1}$; $\mathrm{pH}$ : $6.8-7.5$; Temp: $7.7-7.8^{\circ} \mathrm{C}$

Morphological features of interest. Oval lorica, "boomerang"-shaped in section, slightly convex dorsally. Long foot, protruding from a circular foot opening on the ventral plate of the lorica.

Geographical distribution. Probably cosmopolite. It was first recorded in Spanish reservoirs by Guiset (1976). In the Iberian peninsula it has been found in ponds from Northwest and in Spanish Central region of La Mancha (unpublished data).

Distribution in reservoirs. Guiset (1976) found it in Fervenza (15). In the 1987/88 survey it was also found in winter samples in As Conxas(20), albeit in low numbars.

Testudinellapatina (Hermann, 1783) (Fig. 34 a)

Brachionus patina Hermann, 1783; Proboskidia patina Bory de St. Vincent, 1826; Pterodina patina Ehrenberg, 1830; Pterodina valvata Hudson, 1871; Testudinella patina after Harring, 1913.

Ecology. Heleoplanktonic species. It occurs in plankton when there is abundance of phytobenthos and macrophytes. Euriterm and eurihaline, it tolerates high salinity. It feeds mainly on Chlorella and diatoms.

Cond: $50-541 \mu \mathrm{S} \mathrm{cm}^{-1}$; Alk: $98-3545.5$ peq $\mathrm{l}^{-1}$; pH: 6.3-8-89; Temp: 9.5-24.3 ${ }^{\circ} \mathrm{C}$

Morphologicalfeatures of interest. Lorica almost circular in outline, transparent and depressed, strongly flattened dorso-ventrally. Circular foot opening located almost in the middle of the ventral face; foot wrinkled, toes replaced by a circle of cilia. The form T. patina dendradena (Beauchamp, 1955), was found in two reservoirs characterized by a branched vitellarium and by differences in the apical zone of lorica.

Geographical distribution. Cosmopolite. Recorded frequently in all the Iberian peninsula and Balearic archipelago. It is found specially in reservoirs and littoral ponds.

Distribution in reservoirs. In the $1987 / 88$ survey it was collected in six reservoirs. In Forcadas (13) and Fervenza (15) the form T. patina dendradena (Fig 34 a) was identified. In the previous survey Testudinella patina was found in four localities.

\section{Family CONOCHILIIDAE}

Genus Conochilus Ehrenberg

Traditionally both genera, Conochilus and Conochiloides, have been considered separately, on the basis of differences in the position of the lateral antenna. This fact is very dependent on the coloniality of the species. Ruttner-Kolisko (1974) considered that this feature was not sufficient to warrant the separation into two genera.

Conochilus coenobasis (Skorikov, 1914) (Fig. 35 $\mathrm{m}, \mathrm{n})$

Conochiloides coenobasis Skorikov, 1914; Conochilus dossuarius var coenobasis, Koste, 1978.

Ecology. Euplanktonic species. Warm stenoterm. It feeds preferentially on Trachelomonas (Koste, 1978). The anphoteric reproduction of this species (capacity of females to produce asexual and sexual eggs at the same time) has been described.

Cond: 41-202.3 $\mu \mathrm{S} \mathrm{cm}-1$; Alk: 68.3-711.5 peq $\mathrm{l}^{-1}$; pH: 6.3-9.2; Temp: $7.4-25.2{ }^{\circ} \mathrm{C}$

Morphological features of interest. Both ventral antenna are fused and are situated below the corona. Mouth in the middle of the corona. Asymmetric trophy, with three larger teeth on each uncus. Koste (1978) considered this taxon as a variety of the species Conochilus dossuarius (Hudson, 1885); differences should be found looking at the morphology of the uncus (Fig. 35, $\mathrm{b}, \mathrm{m})$.

Geographical distribution. Cosmopolite. In the peninsular territory it has only been found in reservoirs (Guiset, 1976). 

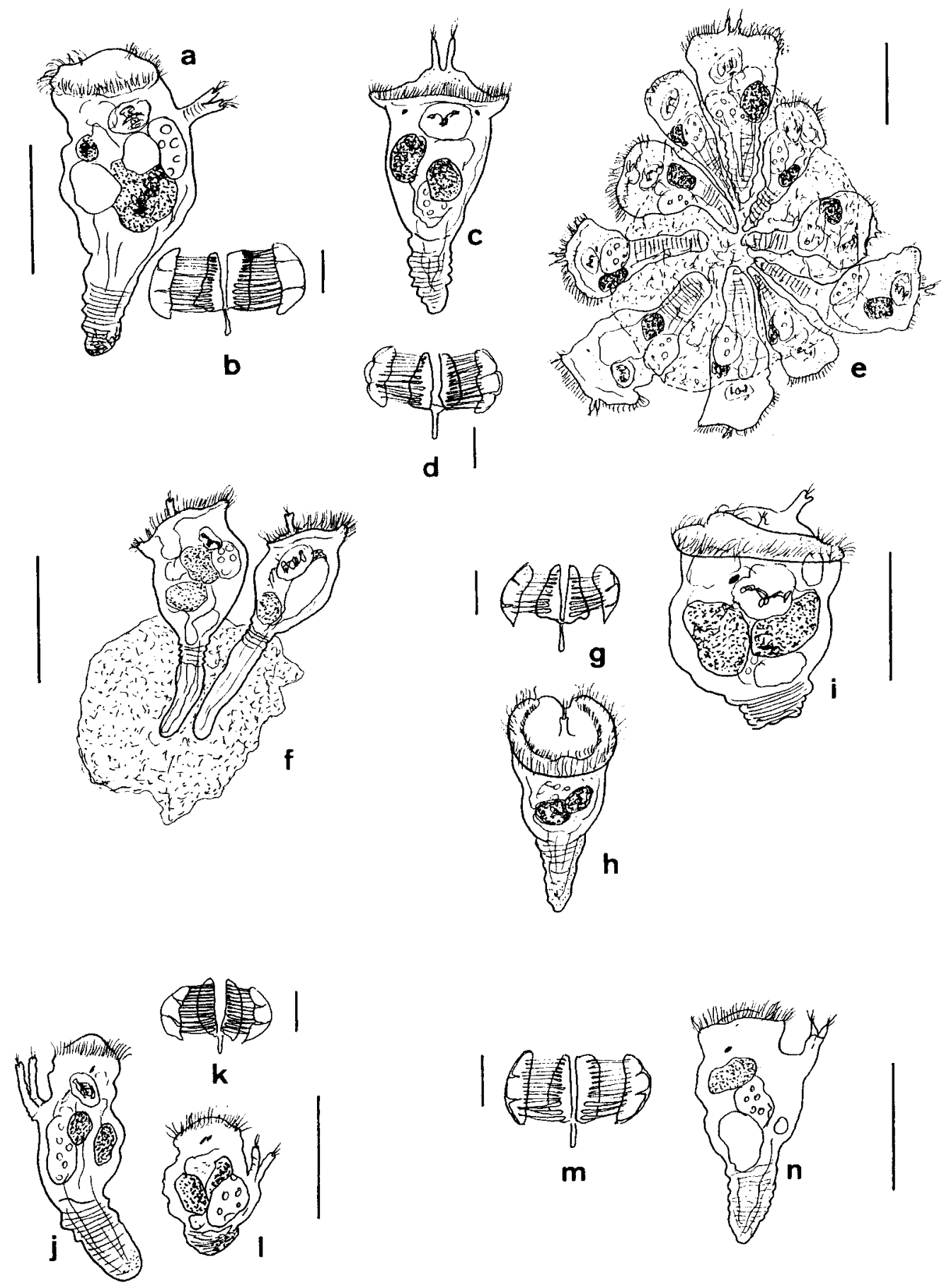

Figura 35. Species of the genus Conochilus found in the Spanish reservoirs during the $87 / 88$ survey. Scale bar is $100 \mu \mathrm{m}$ long (for mastax, $20 \mathrm{um}$ ). a, b, C. dossuarius from Borbollón; c-e, C. hippocrepis, d'El Vado; $\mathrm{f}-\mathrm{i}, \mathrm{C}$. unicornis, from Linares del Arroyo; $\mathrm{j}-1, \mathrm{C}$. natans, from Fervenza; m, n, C. coenobasis, from Guadiloba. Especies del género Conochilus de los embalses españoles (estudio 87/88). Escala: 100 $\mu$ m (mastax $20 \mu \mathrm{m})$. a, b, C. dossuarius de Borbollón; $c-e$. C. hippocrepis, de El Vado; $f-i$, C. unicornis, de Linares del Arroyo; j-l, C. natans, de Fervenza; $m, n$, C. coenobasis, de Guadiloba. 
Distribution in reservoirs. It is was collected in eight reservoirs, all located in the northwestern region of the Iberian Peninsula.

Conochilus dossuarius (Hudson, 1885) (Fig. 35 a,b)

Cephalosiphon dossuurius Hudson, 1886; Conochiloides dossuarius after Hlava, 1904.

Ecology. Euplanktonic species, warm stenoterm. More common in superficial waters. It prefers low alkalinity. According to Boon \& Shiel (1990) it feeds on bacteria.

Cond: $48-1035 \mu \mathrm{S} \mathrm{cm}^{-1}$; Alk: 169-2480peq $\mathrm{l}^{-1}$; pH: 6.8-9.1; Temp: $6.4-24.6^{\circ} \mathrm{C}$

Morphological features of interest. Ventral antenna partly fused. Foot slender. Trophy asymmetrical, with three large teeth on one uncus and five on the other (Fig. 35, b).

Geographical distribution. Cosmopolite. Previous Iberian records of this species can only be found in Monteiro (1984), in Portugal and in Guiset (1976) in Spanish reservoirs and in ephemeral ponds of Doñana National Park (Mazuelos et al., 1993).

Distribution in reservoirs. In the $1987 / 88$ survey it was identified in seven reservoirs. In the previous study of $1972 / 76$ it had been found in six localities all in the northwestern region of the Iberian Peninsula.

Conochilus hippocreppis (Schrank, 1803) (Fig. 35 c-e; Fig. 36)

Linza hippocrepis Skorikov, 1803; Conochilus volvox Ehrenberg, 1834; Ptygura volvox Dujardin, 1841; Megalotrocha volvox, Gosse, 1862; Lacinularia volvox, Schoch, 1868.

Ecology. Planktonic species, it may be found both in ponds and larger waterbodies. Colonial, it may form colonies of 30 to 60 individuals, joined in a gelatinous case. C. hippocreppis is a detritivore, probably feeding on bacteria (Pourriot, 1977).

Cond: $25.8-206.3 \mu \mathrm{S} \mathrm{cm}^{-1}$; Alk: $98-1767$ peq $1^{-1}$; pH: 6.3-8.3; Temp: 6.4-15.4 "C

Morphologicalfeatures of interest. Ventral antennae located on the apical field, either completely separate or only partly fused. Corona "horseshoe"- shaped. Foot once extended may double the length of the body. In preserved material colonies are usually total o partially broken (Fig. 35 e).

Geographical distribution. Cosmopolite. In the Iberian peninsula it has only been found in the Spanish reservoirs (Guiset, 1976).

Distribution in reservoirs. In the $1987 / 88$ survey it was found in four localities, all located in the north. In the previous study, $C$. hippocrepis was more frequently observed, and was collected in 30 samples from 20 reservoirs.

Conochilus natans (Seligo, 1900) (Fig. 35 j-1; Fig. 36)

Tubicolaria natans Seligo, 1900; Conochilus natans after Voigt, 1904; Conochiloides natans after Hlava, 1904.

Ecology. Euplanktonic species. Cold stenoterm; it may be very abundant in lakes and ponds. Solitary, never colonial.

Cond: 22-214.6 $\mu \mathrm{S} \mathrm{cm}$; $^{-1}$ Alk: 58.2-767.4 peq $\mathrm{l}^{-1}$; pH: 6.3-8.6; Temp: $6-20.5{ }^{\circ} \mathrm{C}$

Morphological features of interest. Ventral antennae are long and separate. Posterior end of the body is surrounded by a gelatinous case where eggs are placed. Trophi symmetric, with five or six large teeth on each uncus (Fig $35 \mathrm{k}$ ).

Geographical distribution. Cosmopolite. In the Iberian Peninsula previous records are found in Margalef (1949) from ponds in Baix Urgell (NE, Spain).

Distribution in reservoirs. It has been found in five localities, in the NE of Spain and preferentially in winter (Fig. 36).

Conochilus unicornis (Rousselet, 1892) (Fig. 35 f-i; Fig. 36 )

Conochilus leptopus Forbes, 1893; Conochilus limneticus Stenroos, 1898; Conochilus norvegicus Burckhard, 1943.

Ecology. Euplanktonic species. Colonial; it form colonies of five to 12 individuals. The colony is encased in a gelatinous sheath. Seasonal, it is more frequent in summer. It prefers low to moderate eutrophy.

Cond: $50-576.5 \mu \mathrm{S} \mathrm{cm}{ }^{-1}$; Alk: 98-2002.6 peq $\mathrm{l}^{-1}$; pH: 6.3-8.89; Temp: 7.3-21.2 ${ }^{\circ} \mathrm{C}$ 


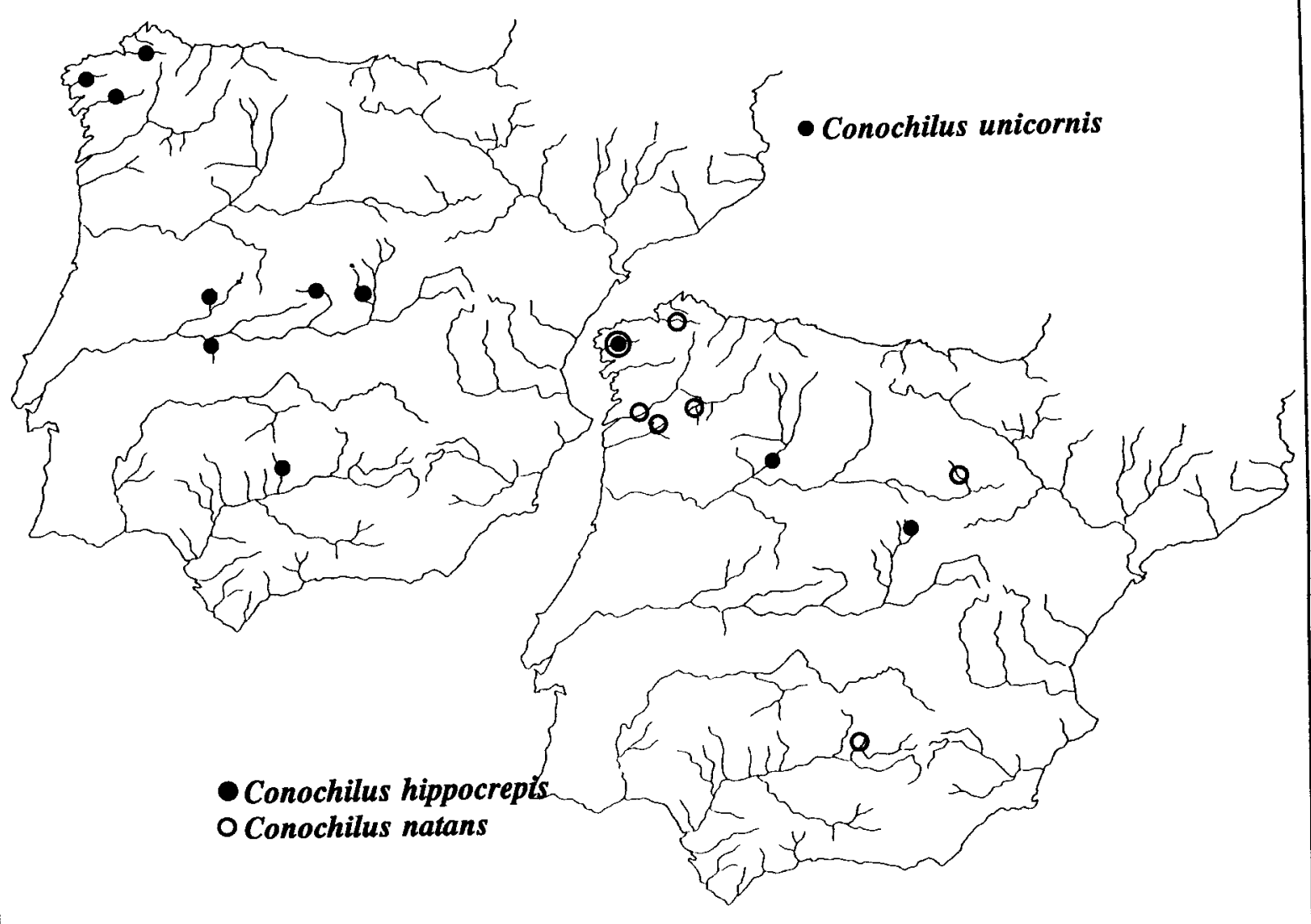

Figura 36. Distribution of some species of the genus Conochilus in Spanish reservoirs (survey 87/88). Distribución de algunas especies del género Conochilus en los embalses esapñoles (estudio 87/88).

Morphological features of interest. Usually colonies are break during fixation. Ventral antenni fused. Extended foot as long as the body. According to Pejler (1956), there is introgression between $C$. unicornis and $C$. hippocrepis, and transition forms can be found. These are characterized by the grade of fusion of their antennae, by the number of individuals of their colonies and by the proportion of the foot to body lenght.

Geographical distribution. Cosmopolite. It has been recorded in the north of the Iberian Peninsula. Margalef (1948b, 1949) and Miracle (1978) found it in Pyrenean lakes. This species has progessively colonized lower latitudes and found in reservoirs south of the Pyrenean mountains.

Distribution in reservoirs. It has been found in 10 reservoirs. In the previous survey it was identified in 25 samples from 17 localities.

Family $H E X A R T H R I D A E$

Genus Hexarthra Schmarda

Hexarthra fennica (Levander, 1892) (Fig. 37 a-c; Fig. 38)

Pedalion fennicum Levander, 1892; Pedalia fennica Harring, 1913; Hexarthra fennica after Neal, 1951. 
Ecology. Euplanktonic species. Eurihaline, it tolerates high salinity. Seasonal, it is found mainly in summer. It is common in coastal ponds.

Cond: 844.6-5326 $\mu \mathrm{S} \mathrm{cm}{ }^{-1}$; Alk: 1913.5$3547.6 \mu$ eq $\mathrm{l}^{-1}$; $\mathrm{pH}: 8.2-8.42$; Temp: $19.3-22.8^{\circ} \mathrm{C}$

Morphological features of interest. Underlip and caudal appendages not present. Seven teeth in uncus (Fig. 37 c). Smaller than Hexarthra mira.

Geographical distribution. Cosmopolite. Frequently found thoughtout the Iberian Peninsula and Balearic archipelago.

Distribution in reservoirs. In the 1987/88 survey it was identified in four reservoirs, all belonging to the oriental region of the Iberian peninsula (Fig. 38). This distribution was similar to that found in the previous survey.
Hexarthra mira (Hudson, 1871) (Fig. 37 d-g; Fig. 38) Pedalion mira Hudson, 1871; Pedalia mira, Barrois, 1878; Pedalion mirum Hudson \& Gosse, 1886; Pedalia mira Harring, 1913;

Ecology. Euplanktonic species. It prefers low mineralization, as opposed to $H$. fennica. Like other species of the genus, H. mira is seasonal and occurs mainly in summer. According to Pourriot (1977), it feeds on detritus and bacteria.

Cond: $14.7-1115.5 \mu \mathrm{S} \mathrm{cm}{ }^{-1}$; Alk: $68.3-3882$ $\mu$ eq $\mathrm{l}^{-1}$; pH: 6.3-10; Temp: $7.8-26.2^{\circ} \mathrm{C}$

Morphological features of interest. Underlip present. Two caudal processes at posterior end (Fig. 37, f). Six teeth on uncus (Fig. 37 e).

Geographical distribution. Cosmopolite. It has been frequently found in Spain.

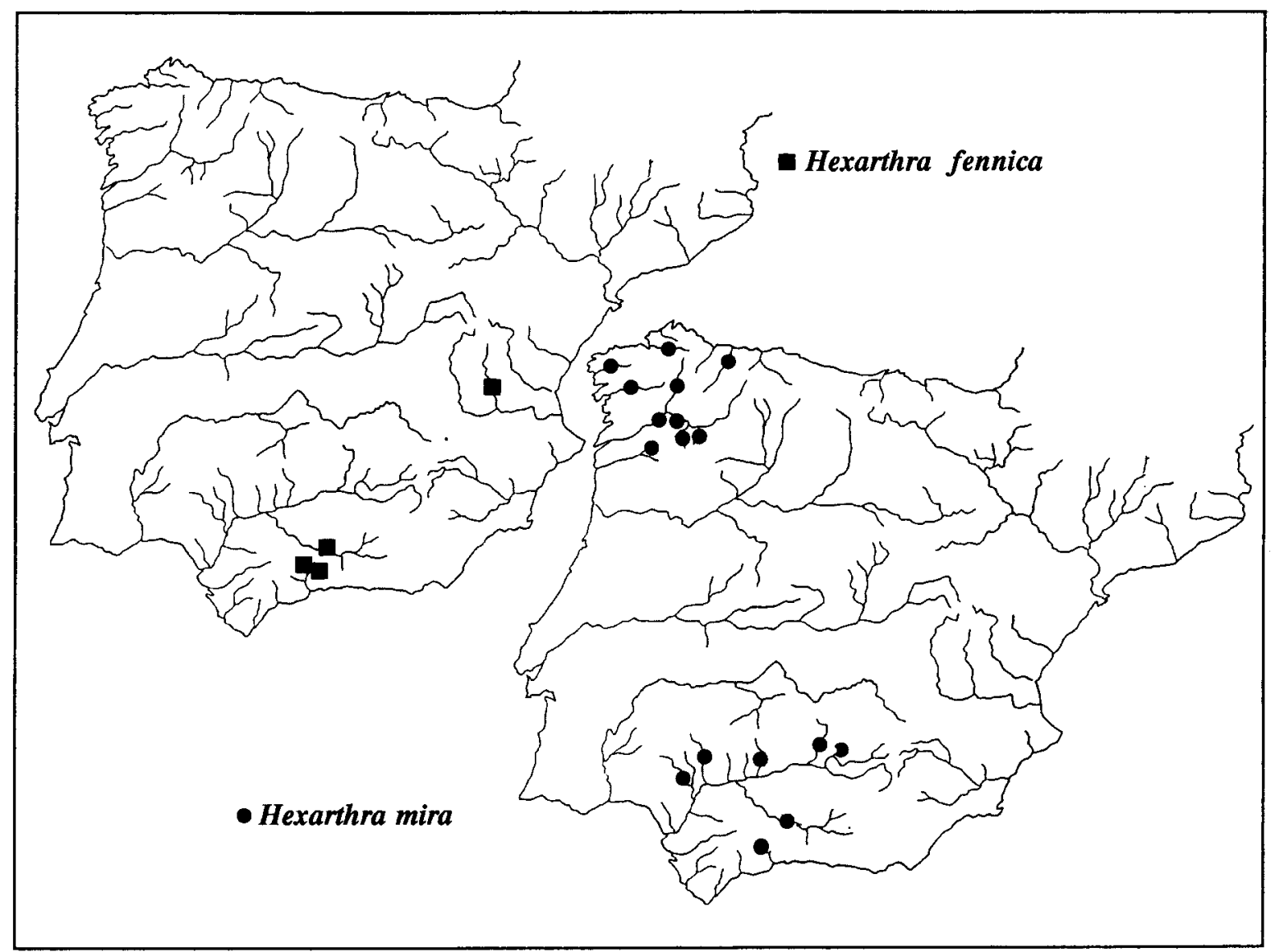

Figura 38. Species of the genus Hexarthra found in Spanish reservoirs (survey 87/88). Especies del género Hexarthra muestreados en los embalses españoles (estudio 87/88). 

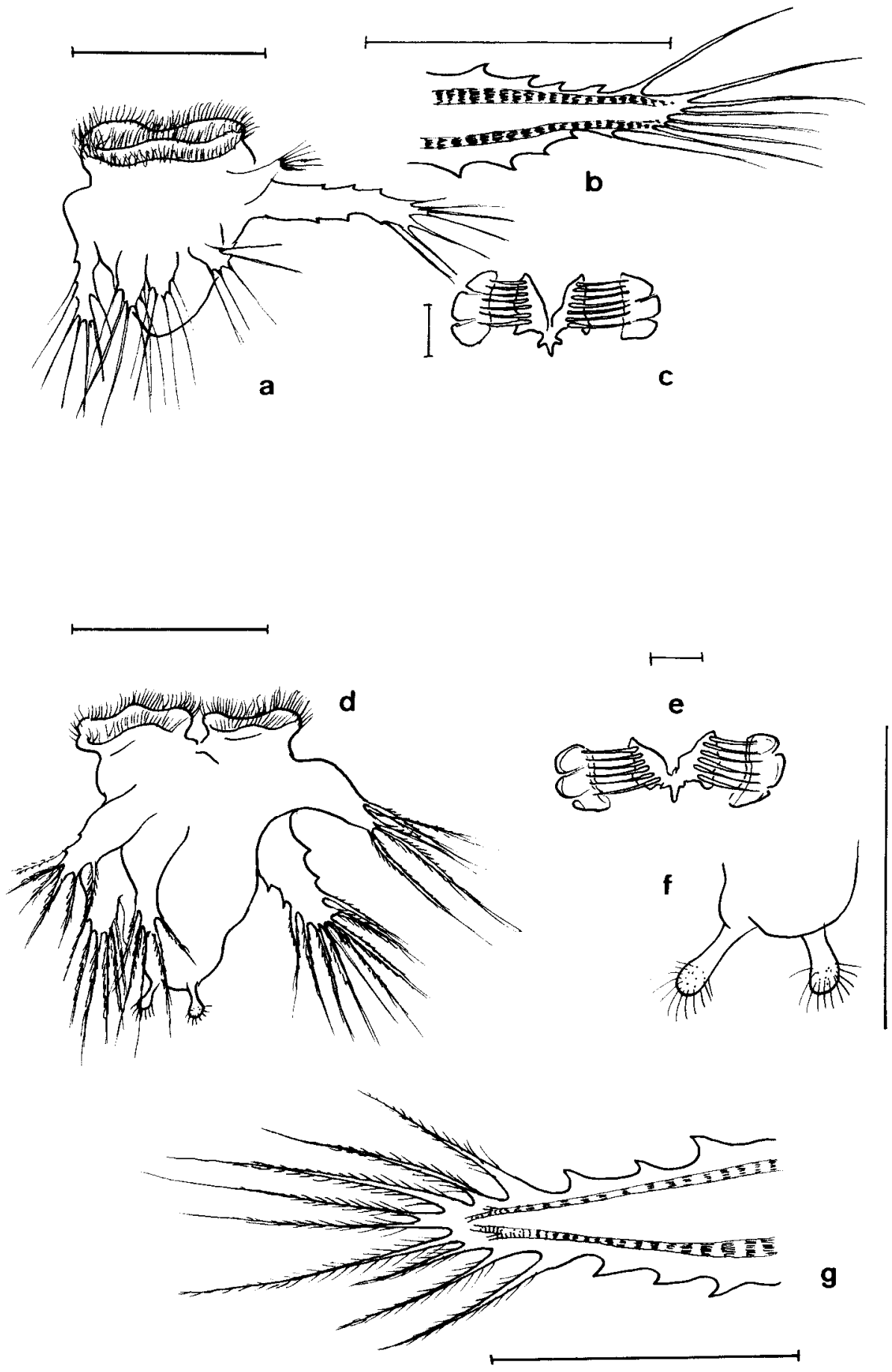

Figura 37. Species of the genus Hexarthra identified in Spanish reservoirs during the $87 / 88$ survey. Scale bars are $100 \mu \mathrm{m}$ long, mastax bars are $20 \mu \mathrm{m}$ long. a-c, Hexarthra fennica, from Puentes, b ventral appendage, c mastax; d-g, H. mira, from Velle, e mastax, f caudal appendages, $g$ ventral appendage. Especies del género Hexarthra identificados en los embalses españoles (estudio 87/88). Escala: 100 $\mu$ m, mastax $20 \mu m$. a-c; Hexarthra fennica, de Puentes, b apendice ventral, c mastax; $d$-g, H. mira, de Velle, e mastax, fapendices caudales, $g$ apéndice ventral. 
Distribution in reservoirs. In the $1987 / 88$ survey it was found in 17 localities, mainly in western region, where there is a predominance of siliceous materials. It was more commonly found during stratification period. In the previous survey it was collected in 39 samples from 34 reservoirs.

\section{Family FILINIIDAE}

Genus Filinia Bory de St. Vincent

There is considerable controversy around classification criteria for species of the genus Filinia. The suggestions given by RuttnerKolisko (1974), based on the biometry of bristles (total length, proportion body length, location) are not enough sufficient to be discriminate at the species level. In addition, these characters have strong variability (Miracle, 1976). Koste (1980), proposed a systhematics based on the trophi morphology (mainly on the number of teeth on uncus). However, in this paper the criteria of Ruttner-Kolisko using features of the bristles, has been adopted for this genus.

Filinia longiseta (Ehrenberg, 1834) (fig. 39 a,b)

Thriarthra longiseta Ehrenberg, 1834;

Ecology. Euplanktonic species. Inhabitant on lakes, ponds, moorlands waters and brackish waters. It prefers warm and eutrophic environments. A filtrerer, according to Pourriot (1965) it feeds mainly on particles 10 to $12 \mu \mathrm{m}$ in size, as detritus, bacteria and algae like Chlorella, it probably competes with species of the genus Conochilus for food.

Cond: $31.5-3720 \mu \mathrm{S} \mathrm{cm} \mathrm{cm}^{-1}$ Alc: 58.2-3882 $\mu$ eq $\mathrm{l}^{-1}$; $\mathrm{pH}$ : 6.3-9.9; Temp: 7.7-26.2 ${ }^{\circ} \mathrm{C}$

Morphological features of interest. Ventrally it presents caudal bristles. These never are on the basal region. Lateral bristles are at least twice as long as those posterior. Several varieties have been described: Filinia longiseta var. limnetica (Zacharias 1893), characterized by a proportion length of lateral bristles to length of caudal bristhe of more than 2. According to Carlin (1943) it has species category (Filinia limnetica). However, Ruttner-Kolisko (1974) considered it an ecological form of $F$. longiseta.
Geographical distribution. Cosmopolite. Widespread in the Iberian peninsula, but records are uncertain, Velasco (1990) (E longiseta / limnetica; $E$ longiseta / terminalis). Probably some of these records correspond to $E$ hofmanni (Koste, 1980).

Distribution in reservoirs. It occurs mainly in summer, in 20 reservoirs. During the mixing period it was found in 13 reservoirs. F. longiseta has an uniform distribution throughout Spain. In the previous survey it was collected in 18 localities, and the limnetica form was found in 30 reservoirs.

Filinia opoliensis (Zacharias, 1898) (Fig. 39 e-g; Fig. 41)

Tetramastix opoliensis Zacharias, I 898; Filinia opoliensis after Remane, 1933.

Ecology. Euplanktonic species. Warm stenoterm. It is found preferentially in large waterbodies with low alkalinity.

Cond: 48-5326.6 $\mu \mathrm{S} \mathrm{cm}{ }^{-1}$; Alk: 266-3882 peq $\mathrm{l}^{-1}$; pH: $7.78-9.16$; Temp: $22.8-26.73^{\circ} \mathrm{C}$

Morphological features of interest. Fusiform. Lateral bristles wide at their base, placed just underneath the corona. Two unequal caudal bristles, of variable length. Microscopic analyses of several mastax showed this species to have 10/11 teeth on the uncus (Fig. 39 g). Some specimens had sexual eggs within their body (Fig. $39 \mathrm{f}$ ).

Geographical distribution. Common in tropical and subtropical regions. In the Iberian Peninsula it has been collected from mainly southern reservoirs.

Distribution in reservoirs. It has been found in 18 localities, all in the south and in summer (Fig. 41).

Filinia terminalis (Plate, 1886) (Fig. 39 c,d)

Thriarthra terminalis Plate, 1886.

Ecology. Euplanktonic species. Cold stenoterm. In reservoirs it was also collected in summer (stratification period). It probably inhabits cooler waters of the hypolimnion although this possibility could not be tested because samples concerned the whole water column. It prefers mesotrophic to eutrophic conditions.

Cond: 22-765.5 $\mu \mathrm{S} \mathrm{cm}$; Alc: 131-3061.5 peq $\mathrm{I}^{-1}$; $\mathrm{pH}$ : $6.64-8.22$; Temp: $7.3-22.8^{\circ} \mathrm{C}$ 


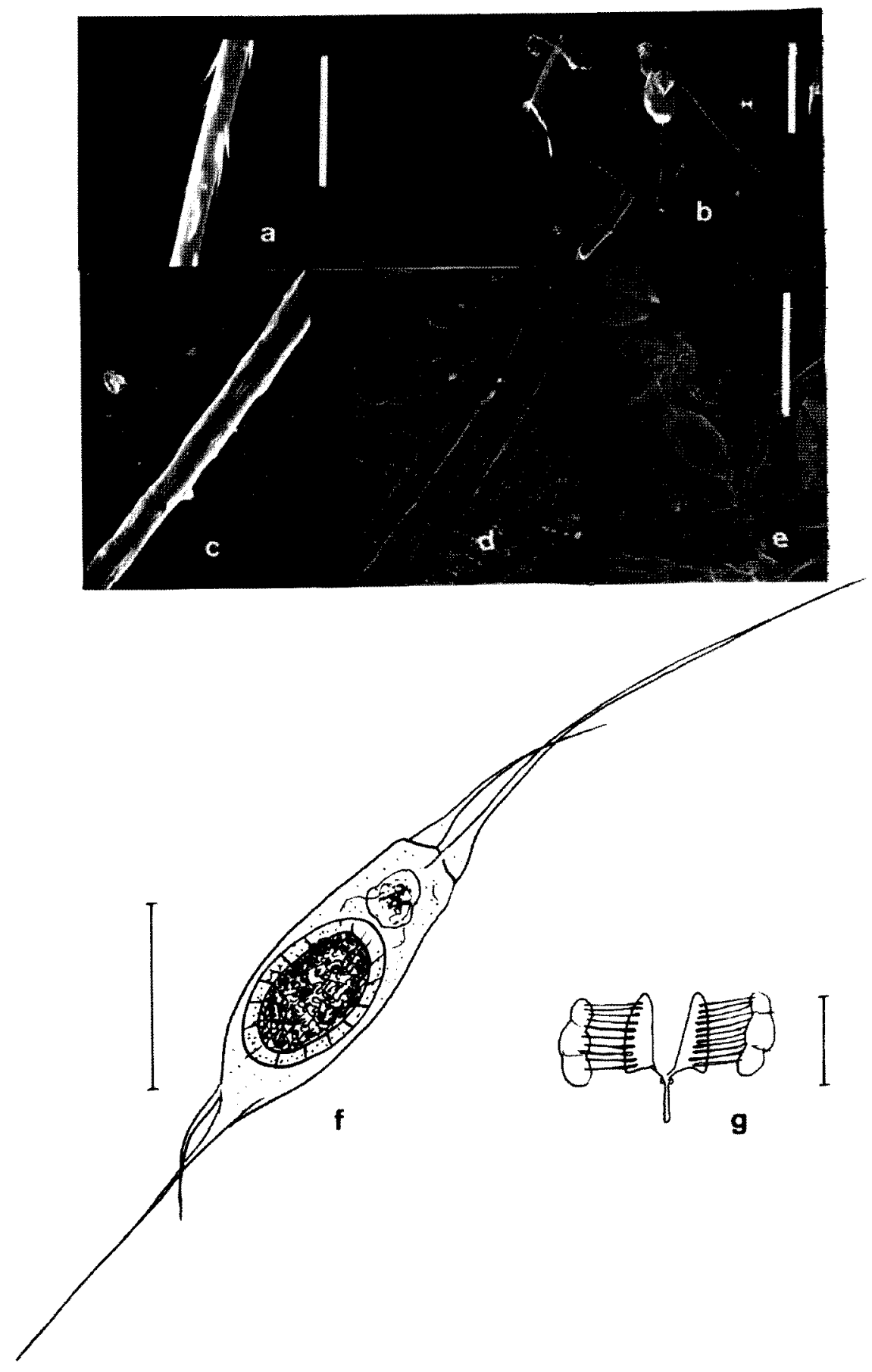

Figura 39. a, b, F longiseta, from Guadalteba, a, SEM micrograph detail showing a lateral bristle (scale bar is $20 \mu \mathrm{m}$ long), b, from Guadalteba (scale is $200 \mu \mathrm{m}$ long); c, d, detail of lateral bristle of $F$. terminalis, from Guadiloba; e, SEM micrograph of $F$. opoliensis, from Guadalmellato (scale bar is $20 \mu \mathrm{m}$ long); $\mathrm{f}, \mathrm{g}$, F opoliensis, from Celemín, scale bar is $100 \mu \mathrm{m}$ long, g, mastax, scale bar is $20 \mu \mathrm{m}$ long. $a$, $b$. F. longiseta, de Guadalteba, a, detalle en MEB de una seda lateral (escala $20 \mu \mathrm{m}), b$, de Guadalteba, escala $200 \mu m ; c, d$, detalle al MEB de una seda lateral de F. terminalis, de Guadiloba; e, microfotografia MEB de F. opoliensis de Guadalmellato (escala $20 \mu \mathrm{m}$ ); $f$, g. F. opoliensis, de Celemin, escala $100 \mu \mathrm{m}, \mathrm{g}$, mastax, escala $20 \mu \mathrm{m}$. 
Morphological features of interest. Terminal posterior bristles on the caudal part ( 0 to $15 \mu \mathrm{m}$ from the end of the body). Posterior bristle are almost as long as lateral ones (length of lateral bristles to length of caudal bristle is approximately 1.2). Ruttner-Kolisko (1974) added to these characters the absence of spines on bristles (Fig. 39 c,d). In this study, as in the previous, and in Miracle (1976) spines could be observed on bristles of this species. Insertion of caudal bristle may be difficult to precise in preserved material too. Koste (1980), in a revision of this genus, proposed as a distinctive character the analysis of the number of teeth on the uncus: $15 / 16$ for $F$. terminalis.

Geographical distribution. Cosmopolite. In Spain it is widespread.

Distribution in reservoirs. In the 1987/88 survey it was found in 14 localities. Four in summer samples, in stratified reservoirs, probably from the hypolimnion. In the previous survey it was collected in 27 samples from 21 localities.

Family COLLOTHECACEAE

Genus Collotheca Harring

Collotheca mutabilis (Hudson, 1885) (Fig. 40 e,g; Fig. 41)

Floscularia mutabilis Hudson, 1885; Collotheca mutabilis after Harring, 1913.

Ecology. Euplanktonic species, in spite of the fact that the genus is mainly represented by benthonic and sessile species. The animal is surrounded by a gelatinous case secreted by foot glands. It prefers warm water, and its occurrence is seasonal, i.e. it is more frequent in summer and autumn.

Cond: $19.6-154 \mu \mathrm{S} \mathrm{cm}{ }^{-1}$; Alk: 116.8-1071.5 peq $\mathrm{I}^{-1}$; pH: 6.6-9.98; Temp: $10.7-22.3^{\circ} \mathrm{C}$

Morphological features of interest. Corona with two lobes, one ventral and one dorsal. There are several long cilia on lobes, longer than the cilia on the corona. These morphological characters on the corona are difficult to appreciate in fixed material. The case is wide, with a rounded end. Foot usually presents a spindle-shaped thickening.
Geographical distribution. Cosmopolite, more frequent in northern regions. It is the first record for the Iberian Peninsula.

Distribution in reservoirs. Identified in five reservoirs, all of them in the northwest (Fig. 41).

Collothecapelagica (Rousselet, 1893)(Fig. 40)

Floscularia pelagica Rousselet, 1893; Collotheca pelagica after Harring, 1913.

Ecology. Euplanktonic species. Typical from large waterbodies. Warm stenoterm. It feeds on flagellate algae (Pourriot, 1965). Guiset (pers. communication) found in its digestive tract peridinidae (12 to $28 \mu \mathrm{m}$ in size), Cyclotella, Cosmarium, small flagellates and chlorococcales.

Cond: $14-3600 \mu \mathrm{S} \mathrm{cm}$; Alk: 58.2-4681.7 peq $\mathrm{l}^{-1}$; pH: 6.3-9.6; Temp: $5.9-26.2^{\circ} \mathrm{C}$

Morphological features of interest. Corona unlobed, circular, although long cilia occur in five groups. These cilia are difficult to distinguish in fixed material. Foot is root-shaped and sometimes thickened.

Geographical distribution. Cosmopolite. In Spain it has only been collected in reservoirs (Guiset, 1976, Telleria, 1981).

Distribution in reservoirs. It is one of the most common species in Spanish reservoirs. It has been collected in 40 reservoirs in summer and 52 in winter.

BDELLOIDEA (DIGONONTA)

Family PHILODINIDAE

Genus Rotaria Scopoli

Rotaria neptunia (Ehrenberg, 1832) (Fig. 42)

Actinurus neptunius Ehrenberg, 1832; Rotifer neptunius Jennings, 1900; Rotaria neptunia, after Voigt, 1957.

Ecology. Heleoplanktonic species, occurring occasionally in plankton. Polisaprobic, typical from eutrophic waterbodies with high alkalinity. It may survive low oxygen concentrations.

Cond: $150-655.5 \mu \mathrm{S} \mathrm{cm}{ }^{-1}$; Alk: 1034.5-3882 $\mu$ eq $\mathrm{l}^{-1}$; $\mathrm{pH}: 7.5-8.8$; Temp: $9.5-26.2^{\circ} \mathrm{C}$

Morphological features of interest. Large, telescopic body, with a long segmented foot, ending with two spurs in the last segment. In the reservoirs studied, this species has been the only 

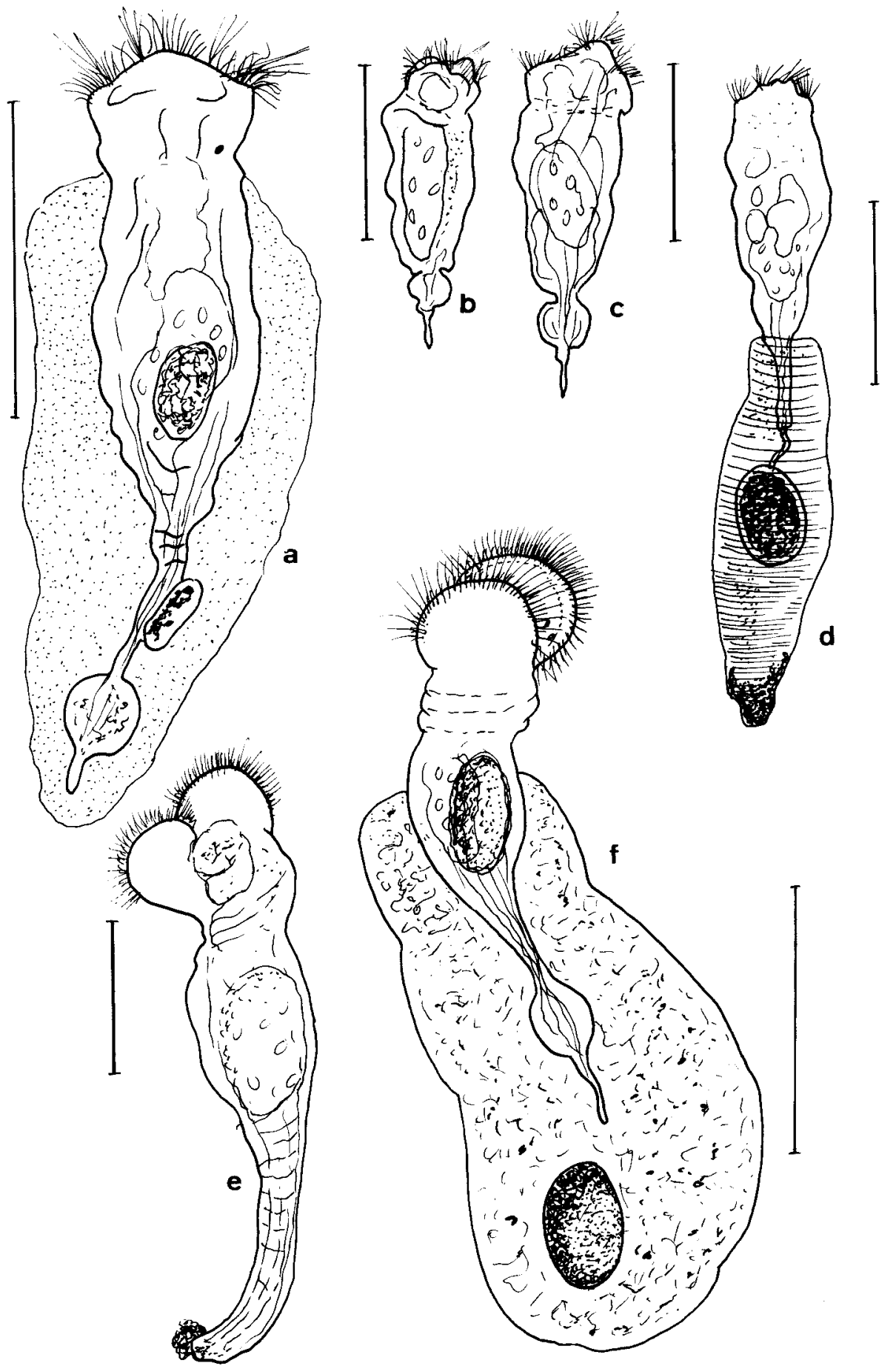

Figura 40. Species of the genus Collotheca in Spanish reservoirs found during the $87 / 88$ survey. a-d, Collotheca pelagica, a from Jándula, $\mathrm{b}, \mathrm{c}$, from Portodemouros, d, from Arbón. e, f, Collotheca mutabilis, from Portodemouros. Scale bar $100 \mu \mathrm{m}$. Especies del género Collotheca en los embalses españoles (estudio 1987/88). a-d, Collotheca pelagica, a de Jándula, b,c, de Portodemouros, d, de Arbón. e, $f$. Collotheca mutabilis, de Portodemouros. Escala $100 \mu \mathrm{m}$. 


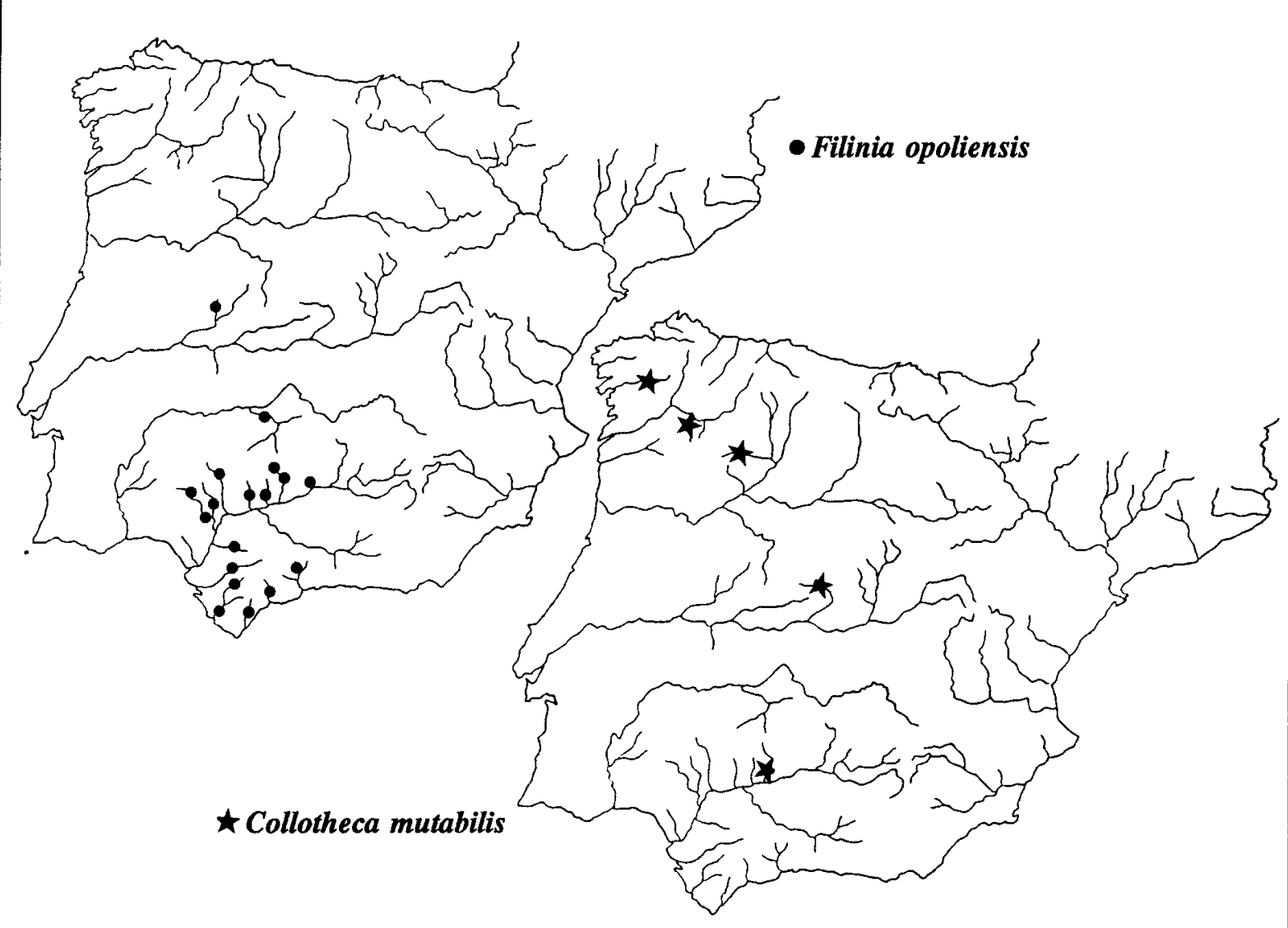

Figura 41. Distribution of some species of the genera Filinia and Collotheca in Spanish reservoirs found during the 87/88 survey. Distribución de algunas especies de los géneros Filinia y Collotheca en los embalses españoles (estudio 87/88).

bdelloidea whose taxonomic identity could be ascertained. Some individuals did not contract during preservation with formaldehyde or did so poorly, facilitating identification

Geographical distribution. Cosmopolite. It has been found in several Spanish localities, all in the north. Its presence may be expected, though, more southern latitudes in Spain.

Distribution in reservoirs. It has been collected occasionally and with low abundance in the plankton samples from four reservoirs: Oliana (95), Sobrón (91), La Tranquera (33) and Guadalmellato (66).

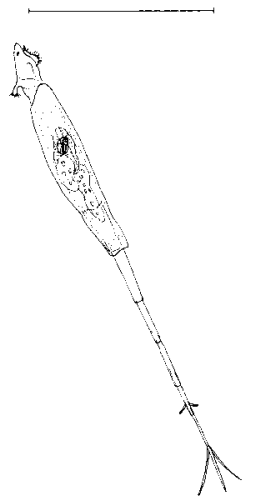

Figura 42. Rotaria neptunia, from Oliana. Scale bar is $100 \mu \mathrm{m}$ long. Rotaria neptunia, de Oliana. Escala: $100 \mu \mathrm{m}$. 


\section{ACKNOWLEDGEMENTS}

My sincere thanks to the colleagues of the Departament d'Ecologia (Universitat de Barcelona) who participate in surveys. Specially thanks go to to Montserrat Real, Eugènia Martí, Francesc Sabater, Josep Anton Morgui, Joan Lluis Riera and Damià Jaume.

I would also like to express my gratitude to Albert Guiset for facilitating data on rotifers of the previous survey of reservoirs and Joan Armengol for his unconditional support and for the revision of a first draft. SEM photographs were taken in the Servei de Microscopia Electrònica de la Universitat de Barcelona.

Reservoir surveys were financed by Comission Assessora de Investigación Cientifica y Técnica (CICYT) grant PB 85-0166 and sponsored by the Dirección General de Obras Hidráulicas of the Ministerio de Obras Publicas.

\section{REFERENCES}

AHLSTROM, E.H. 1940. A revision of the rotatorian genera Brachionus and Platyias with descriptions of one new species and two new varieties. Bull. Am. Mus. Nat. Hist., 77: 143-84.

AHLSTROM, E.H. 1943. A revision of the rotatorian genus Keratella with descriptions of three new species and five new varieties. Bull. Am. Mus. Nat. Hist., 80: 411-57.

ANSELLEM, J. \& P. CLEMENT, 1980. A simplified method for the preparation of rotifers for transmission and scanning electron microscopy. Hydrobiologia, 73: 119-122.

AREVALO,C., 1918. Datos para els conocimiento del plancton de agua dulce en Barcelona. Trab. de la Soc. de Biol.,: 127-131.

AREVALO, C., 1923. El lago de Carucedo. Mem. de la Real Soc. Esp. de H. N., 11 (8): 305-330.

AREVALO, C., 1932. Investigaciones recientes en los laboratorios de Polonia sobre Hidrobiologia espaiiola. Reseñas científicas de la Soc. Esp. de H. N., $6(3 / 4)$ : 140-143.

ARMENGOL, J., M. ESTRADA,A. GUISET, R. MARGALEF, D. PLANAS, J. TOJA \& F. VALLESPINOS, 1975. Observaciones limnológicas en las lagunas de la Mancha. Bol. Est. Cent. Ecol. (Icona), 4 (8):11-27.
ARMENGOL J., J. CATALAN, N. GABELLONE, D. JAUME, J. de MANUEL, E. MARTI, J.A. MORGUI, J. NOLLA, J. PENUELAS, M. REAL, J.L. RIERA, S. SABATER, F. SABATER \& J. TOJA, 1990. A comparative limnological study of the Guadalhorce reservoirs system (Màlaga, S.E. Spain). Scientia gerundensis, 16 (2): 27-41.

BARTOS, E., 1959. Rotatoria. Fauna C.S.R. 15, 1-969.

BEAUCHAMP, P. de, 1952. Un facteur de la vaiabilité chez les rotifères du genre Bruchionus. C. $R$. Acad. Sci., Paris 234: 573-575.

BERZINS, B., 1962. Revision der Gattung Anuraeopsis Lauterbom (Rotatoria). K. Fysiogra. Sällsk. Lund. Forh., 32: 33-47.

BERZINS, B., 1978. Rotatoria. In: Limnofauna Europea. J. Illies, (ed.): 54-91. G. Fisher, Stuttgart.

BERZINS, B. \& B. Pejler, 1987. Rotifer occurrence in relation to $\mathrm{pH}$. Hydrobiologiu, 147: 107-116.

De MANUEL, J. 1991. Distribution of the Brachionidae (Rotifera: Monogononta) in Spanish reservoirs. Verh. Internat. Verein. Limnol., 24: 2741-2744.

De MANUEL, J. 1997. Rotifers dels embassaments espanyols peninsulars: ecologia $i$ aspectes sistematics $i$ zooogeogràfics. Tesis Doctoral. Universitat de Barcelona.

De MANUEL, J. \& D. JAUME. 1993. Zooplankton of reservoirs from the River Ebro basin (Spain): Relationships with some physical, chemical and biological features. Verh. Internat. Verein. Limnol. 25, (2): 1236-1241

De MANUEL, J. \& D. JAUME. 1994. Zooplankton from reservoirs of the Guadalquivir river basin (Spain). Archiv fur Hydrobiol. Beih. Ergebn. Limnol., 40: 107-116.

De MANUEL, J. \& J. ARMENGOL. 1993. Rotifer assemblages: a contribution to the typology of Spanish reservoirs. Hydrobiologia, 255/256: 421 428.

De MANUEL, J., J.L. PRETUS \& D. JAUME, 1992. Rotifers from the Balearic archipelago. Hydrobiologia, 239: 33-41.

De RIDDER, M. 1962. Recherches sur les rotiferes des eaux saumatres. VIII Quelques rotiferes des Marismes espagnoles. Hydrobiologia, 20 (1): 92-109.

DONNER, J. 1970. Die Radierbestande submerser Moose der Salzach und anderer Wasser-Biotope des Flussbebietes. Arch. Hydrobiol. Suppl., 27: 227324.

DUMONT, H.J., 1980. Workshop on taxonomy and biogeography. Hydrobiologia, 73: 205-206. 
DUMONT, H.J., 1983. Biogeography of rotifers. Hydrobiologia, 104: 19-30.

EDMONDSON, W.T., 1935. Some Rotatoria from Arizona. Trans. Am. Microscop. Soc., 54: 459-473.

EDMONDSON, W.T.\& A.H. LITT, 1989. Morphological variation in Kellicottia longispina. Hydrobiologia, 186/187: 109-117.

ESPARCIA, A., M.R. MIRACLE \& M. SERRA, 1989. Brachionus plicatilis tolerance to low oxygen concentration. Hydrobiologia, 186/187: 331-337.

FORES, E., M. MENENDEZ \& F. COMIN. 1986. Contribución al conocimiento de crustáceos y rotiferos del Delta del Ebro. Mis. Zool., 10: 105-11.

GILBERT, J.J., 1967. Asplanchna and postero-lateral spine production in Brachionus calyciflorus. Arch. Hydrobiol., 64 (1): 1-62.

GILBERT, J.J., 1980. Feeding in the rotifer Asplanchna: Behaviour, canibalism, selectivity, prey difuses, and impact on rotifer communities. In: Evolution and Ecology of Zooplancton Communities. W.C. Kerfoot (ed.): 158-172. University Press of New England.

GILBERT, J.J. \& W. BIRKY Jr., 1971. Sensitivity and specificity of the Asplanchna response to dietary atocopherol. J. Nutr., 101: 113-126.

GUISANDE, C. \& J. TOJA, 1988. The dynamics of various species of the genus Brachionus (Rotatoria) in the Guadalquivir river. Arch. Hydrobiol. 112 (4): 579-595.

GUISET, A., 1976. Rotiferos. In: Margalef, R., D. Planas, J. Armengol, A. Vidal, N. Prat, A. Guiset, J. Toja \& M.Estrada, 1976: Limnología de los embalses españoles. Dir. Gral. Obras Hidraulicas, Ministerio de Obras Publicas, Public n. 123. Madrid.

GUISET, A., 1977a. General distribution of planktonic rotifers in Spanish reservoirs. Arch. Hydrobiol. Beih., 8: 222-225.

GUISET, A., 1977b. Some data on variation in three planktonic genera.Arch. Hydrobiol. Beih., 8: 237-239.

GUISET, A. 1977c. Stomach content in Asplanchna and Ploesoma. Arch. Hydrobiol. Beih., 8:126-129.

GUISET, A. \& De MANUEL, J. 1993. Distribution of planktonic rotifers in Spanish reservoirs: Changes after 15 years. Verh. Internat. Verein. Limnol., 25, (2): 1213-1217.

HARRING, H.K. 1916. A revision of the rotatorian genera Lepadella and Lophocharis with description of five new species. Proc. U.S. Nat. Mus., 51:527-567.

HARRING, H.K. \& F.J. MYERS. 1922. The Rotifer fauna of Wisconsin. Trans. Wisc. Acad. Sci. Arts Lett., 20: 553-662.
HARRING, H.K. \& F.J. MYERS. 1926. The Rotifer fauna of Wisconsin. III. A revision of the genera Lecane and Monostyla. Trans. Wisc. Acad. Sci. Arts Lett., 22: 315-423.

HAUER, J. 1924.Zur Kenntnis des Rotatorien-Genus Colurella, Bory de st. Vincent. Zool. Anz., 59: 177-186.

KING, C.E. 1989. Molecular genetics of rotifers: preliminarly restriction mapping of the mitochondrial genome of Brachionus plicatilis. Hydrobiologia, 186/187: 375-380.

KING, C.E.\& T.W. SNELL. 1977. Sexual recombination in rotifers. Heredity, 39: 357-360.

KOSTE, W., 1978. Rotatoria. Die Riidertiere Mitteleuropas (Uberordnung Monogononta) Bestimmungswerk begründet von Max Voigt. 2 Vols. (Borntraeger, Stuttgart).

KOSTE, W. 1980a. Uber zwei Plankton-Radertiere taxa, Filinia australiensis n. sp. und Filinia hofmanni n. sp., mit Bemerkungen zur Taxonomie der longiseta-terminalis Gruppe. Genus Filinia Bory de St. Vicent, 1824, Familie Filiniidae, Bartos, 1959, (Uberordung Monogononta). Arch. Hydrobiol., 90 (2):230-256.

KOSTE, W. 1980b. Das Radertier-Portrat Brachionus plicatilis, ein Salzwasser-radertier. Mikrokosmos 69: 148-155.

KOSTE, W. 1982. Das Radentier-Portrat Ploesoma truncatum, ein rauberisches Planktonradentier. Mikrokosmos, 6: 167-173.

KOSTE, W., \& R.J. SHIEL. 1987a. Rotifera from Australian inland waters. II. Epiphanidae and Brachionidae (Rotifera: Monogononta). Invert. Taxon., 1: 949-1021.

KOSTE, W. \& R.J. SHIEL. 1987b. Tasmanian rotifera: afinities with the australian fauna. Hydrobiologia, 147: 31-43.

KOSTE, W., \& R.J. SHIEL. 1989a. Rotifera from Australian inland waters. III. Euchlanidae, Mytilinidae \& Trichotriidae. Trans. R. Soc. S. Aust. 113: 85-114.

KOSTE, W., \& R.J. SHIEL. 1989b. Rotifera from Australian inland waters. IV. Colurellidae. Trans. R. Soc. S. Aust., 113: 119-143.

KOSTE, W. \& R.J. SHIEL. 1989c. Classical taxonomy and modern methodology. Hydrobiologia 186/187: 279-284.

KOSTE, W., \& R.J. SHIEL. 1990a. Rotofera from Australian inland waters V. Lecanidae (Rotifera Monogononta). Trans. R. Soc. S. Aust. 114 (1): 1-36.

KOSTE, W., \& R.J. SHIEL. 1990b. Rotifera from Australian inland waters, VI. Proalidae and 
Lindiidae (Rotifera: Monogononta). Trans. R. Soc. S. Aust., 114(1): 129-143.

KOSTE, W., \& R.J. SHIEL. 1991. Rotifera from Australian inland waters, VII. Notommatidae (Rotifera: Monogononta). Trans. R. Soc. S. Aust., 115 (3): 111-159.

MAKAREWICZ, J.C., \& G.E. LIKENS, 1979. Structure and function of the zooplankton community of Mirror Lake, New Hampshire. Ecol. Monogr., 49: 109-127.

MARGALEF, R., 1948a. Notas sobre algunos rotíferos. P. Inst. Biol. Apl., 4:136-143.

MARGALEF, R., 1948b. Flora, fauna y comunidades bióticas delas aguas dulces del Pirineo de la Cerdaña. Monografías de la Estación de Estudios Pirenaicos, $n^{\circ}$ 11, Biologiu-2: 226p.

MARGALEF, R., 1949. segunda nota sobre la biología de las aguas estancadas del Bajo Urgel. Ilerda, 13: 331-375.

MARGALEF, R., 1955. Contribucidn al estudio de la fauna de las aguas dulces del Noroeste de Espaiia. P. Inst. Biol. Apl., 21: 137-171.

MARGALEF, R., 1973. Composicid del plàncton vegetal de diversos llacs artificials de Catalunya. Treb. Soc. Cut. Biol., 32: 171-179.

MARGALEF, R., D. PLANAS, J. ARMENGOL, A. VIDAL, N. PRAT, A. GUISET, J. TOJA \& M. ESTRADA. 1976: Limnología de los embalses españoles. Dir. Gral. Obras Hidráulicas, Ministerio de Obras Publicas, Public n. 123. Madrid. 422 + 85 pp.

MAZUELOS, N., J. TOJA \& C. GUISANDE. 1993. Rotifers in ephemeral ponds of Doiiana National Park. Hydrobiologia, 255/256: 429-434.

MENENDEZ, M. \& F.A. COMIN. 1986. Variacidn estacional del zooplancton de las lagunas costeras del Delta del Ebro (N.E. Espaiia). Oecologia aquatica, 8: 47-60.

MIRACLE, M.R. 1976. Distribucidn en el espacio y el tiempo de las especies de zooplancton del lago de Banyoles. Monografias del ICONA, 5: 270 pp.

MIRACLE, M.R. 1978. Composición específica de las comunidades zooplanctdnicas de 153 lagos de los Pirineos y su interés biogeográfico. Oecologia aquutica, 3: 167-191.

MIRACLE, M.R. \& E. VICENTE. 1983. Vertical distribution and rotifer concentrations in the chemocline of meromictic lakes. Hydrobiologiu, 104: 259-267.

MONTEIRO, M.T. 1984. Ciclo anual do zooplancton de uma albufeira recem formada. Odivelas. Bol. Inst. Invest. Pescas., 11:71-81.
MORALES-BAQUERO, R. 1987. Rotifer fauna of lakes and ponds over $2500 \mathrm{~m}$ above sea level in the Sierra Nevada, Spain, with description of a new subspecies. Hydrobiologia, 147: 97-101.

NIPKOW, F., 1961. Die Radertiere im Plankton des Zurichsees und ihre Entwicklunngsphasen. Ibid. 23: 398-461.

OLTRA, R., \& M.R. MIRACLE, 1984. Comunidades zooplanctónicas de la Albufera de Valencia. Limnetica, $1: 5$ 1-56.

PEJLER, B. 1956. Introgression in planktonic rotatoria with some points of view on its causes and coincevable results. Evolution, 10: 246-261.

PEJLER, B. 1957. On variation and evolution in planktonic rotatoria. Zool. Bidr: Uppsala, Bd 32: $1-66$.

PEJLER, B. 1962. Taxonomic notes on some planktic fresh-water rotifers. Zool. Bidr: Uppsala, Bd 35: 307-319.

PEJLER, B. 1977. On the global distribution of the family Brachionidae (Rotatoria). Arch. Hydrobiol. Suppl., 53: 255-306

PONTIN, R.M. 1978. A key to the freshwater planktonic and semi-planktonic rotifera of the British Isles. Freshw. Biol.Assoc., Scient. Publicat., 38: 178 pp.

POURRIOT, R. 1965. Recherches sur l'écologie des Rotifères, Vie et Milieu, supp 21: 224 pp.

POURRIOT, R. 1970. Quelques Trichocerca (Rotifères) et leurs régimes alimentaires. Ann. Hydrobiol., 1 (2): 155-171.

POURRIOT, R. 1974. Relations prkdateur-proies chez les rotifkres: Influence du prédateur (Asplanchna brightwelli) sur la morphologie de la proie (Brachionus bidentata). Ann. Hydrobiol., 5: 43-55.

POURRIOT, R. 1977. Food and feeding habits of Rotifera. Arch. Hydrohiol. Beih., 8: 243-260.

POURRIOT, R. \& A.J. FRANCEZ. 1986. Introduction practique a la systematique des organismes des eaux continentales francaises. Bull. Soc. Linn., Lyon 55 (5): 1-37.

PRETUS, J.Ll., De MANUEL, J. \& Ll. CARDONA. 1992. Temporal heterogeneity, zooplankton composition and fishfood supply in the Albufera of Minorca, a highly fluctuant environment. Bulletin de l'Institut oceanographique Monaco, $\mathrm{n}^{\circ}$ especial 11: 179-188.

REMANE, A. 1929-1933. Rotatoria. In: Klassen und Ordnungen des Tierreichs. H. G. Bronn (ed.) 4 Vols. (Leipzig).

RIERA, J.L., E. MARTI \& J.A. MORGUI. 1991. Changes in the trophic state of the Spanish reser- 
voirs during the last sixteen years. Verh. Internat. Verein. Limnol., 24: 1367-1370.

RIERA, J.L., D. JAUME, J. De MANUEL, J.A. MORGUI \& J. ARMENGOL. 1992. Patterns of variation in thelimnology of Spanish reservoirs: a regional study. In Limnology in Spain (Ed. C. Montes \& N. Prat). Limne'tica, 8: 111-123.

ROJO, C.\& R. OLTRA, 1986. Introducción al estudio de las comunidades planctonicas del río Serpis ensu tramo medio. Limne'tica, 2: 253-257.

RUTTNER-KOLISKO, A. 1974. Plankton Rotifers, biology and taxonomy. Binnengewasser, 26 Suppl:146p.

SALT, G.W., 1977. An analysis of the diets of five sympatric species of Asplanchna. Archiv. Hydrobiol. Beih., 8: 123-125.

SEGERS, H., 1993. Rotifera of some lakes in the floodplain of the River Niger (Imo State, Nigeria). I. New species and other taxonomic considerations. Hydrobiologia, 250: 39-61.

SELGA, D., 1952. Contribución al conocimiento de los Rotiferos de España. I. Rotiferos de las aguas continentales españolas y su distribución. P. Inst. Biol. Apl., 11: 113-123.

SERRA, M., 1987. Variacidn morfométrica, isoenzima'tica y demográfica en poblaciones de Brachionus plicatilis: diferenciacidn gene'tica y plusticidad fenotípica. Tesis Doctoral. Universitat de València.

SERRA, M. \& M.R. MIRACLE, 1983. Biometric analysis of Brachionus plicatilis ecotypes from Spanish lagoons. Hydrobiologia, 104: 279-291.

SHIEL, R.J \& W. KOSTE. 1986. Australian Rotifera: Ecology and Biogeography Eds. De Decker and W.D. Williams CSIRO: Melbourne/Dr. W. Junk: Dordrecht. Limnology in Australia, pp 141-150.

SHIEL, R.J. \& W. KOSTE, 1992. Rotifera from Australian inland waters, VIII. Trichocercidae (Monogononta). Trans. R. Soc. S. Aust., 116: 1-27.
SHIEL, R.J., W. KOSTE \& L.W. TAN. 1989. Tasmania revisited: rotifer communities and habitat heterogeneity. Hydrobiologia, 186/187: 239-245.

SLADECEK, V., 1983. Rotifers as indicators of water quality. Hydrobiologia, 100: 169-201.

SNELL, T.W. \& C.A. HAWKINSON. 1983. Behavioral reproductive isolation among populations of the rotifer Brachionus plicatilis. Evolution, 37 (6): 1294-1305.

STEMBERGER, R.S., 1979. A guide to rotifers of the Laurentian Great Lakes. US EPA, Report EPA 600/4-79-021.

STEMBERGER, R.S., 1987. The potential for population growth of Ascomorpha ecaudis. Hydrobiologia, 147: 297-301.

STEMBERGER, R.S., 1990. Food limitation spination, and reproduction in Brachionus calyciforus. Limnol. Oceanogr., 35 (1):33-44.

STEMBERGER, R.S. \& J.J. GILBERT, 1984. Spine development in the rotifer Keratella cochlearis: induction by cyclopoid copepods and Asplanchna. Fresh. Biol., 14: 639-647.

SUDZUKI, M., 1987. Intraspecific variability of Brachionus plicatilis. Hydrobiologia 147: 45-47.

TELLERIA, L.J., 1981. Limnologia del embalse de Lertutxe. Actas del $I^{\text {er }}$ Congreso Español de Limnologia, p: 295.

VELASCO, J.L., 1990. Lista faunística y bibliográfica de los Rotíferos (Rotatoria) de la Peninsula Ibérica e Islas Baleares y Canarias. Listas de la flora y fauna de las aguas continentales de la peninsula ibérica. AEL, Public., 8: 195 pp.

VOIGT, M. 1957. Rotatoria. Die Radertiere Mitteleuropas. 2 Vols. (Borntraeger, Berlin).

WALKER, K.F. 1981. A synopsis of ecological information on the saline lake rotifer Brachionus plicatilis Müller 1786 Hydrobiologia, 8I : 159-167.

WISZNIEWSKI, J. 1931. Sur quelques Rotiferes trouvés en Espagne. Arch. Hidrob. et Ichtyol., 6: 41-64. 